Prepared in cooperation with the National Park Service

\title{
Characterization of Major-Ion Chemistry and Nutrients in Headwater Streams Along the Appalachian National Scenic Trail and Within Adjacent Watersheds, Maine to Georgia
}

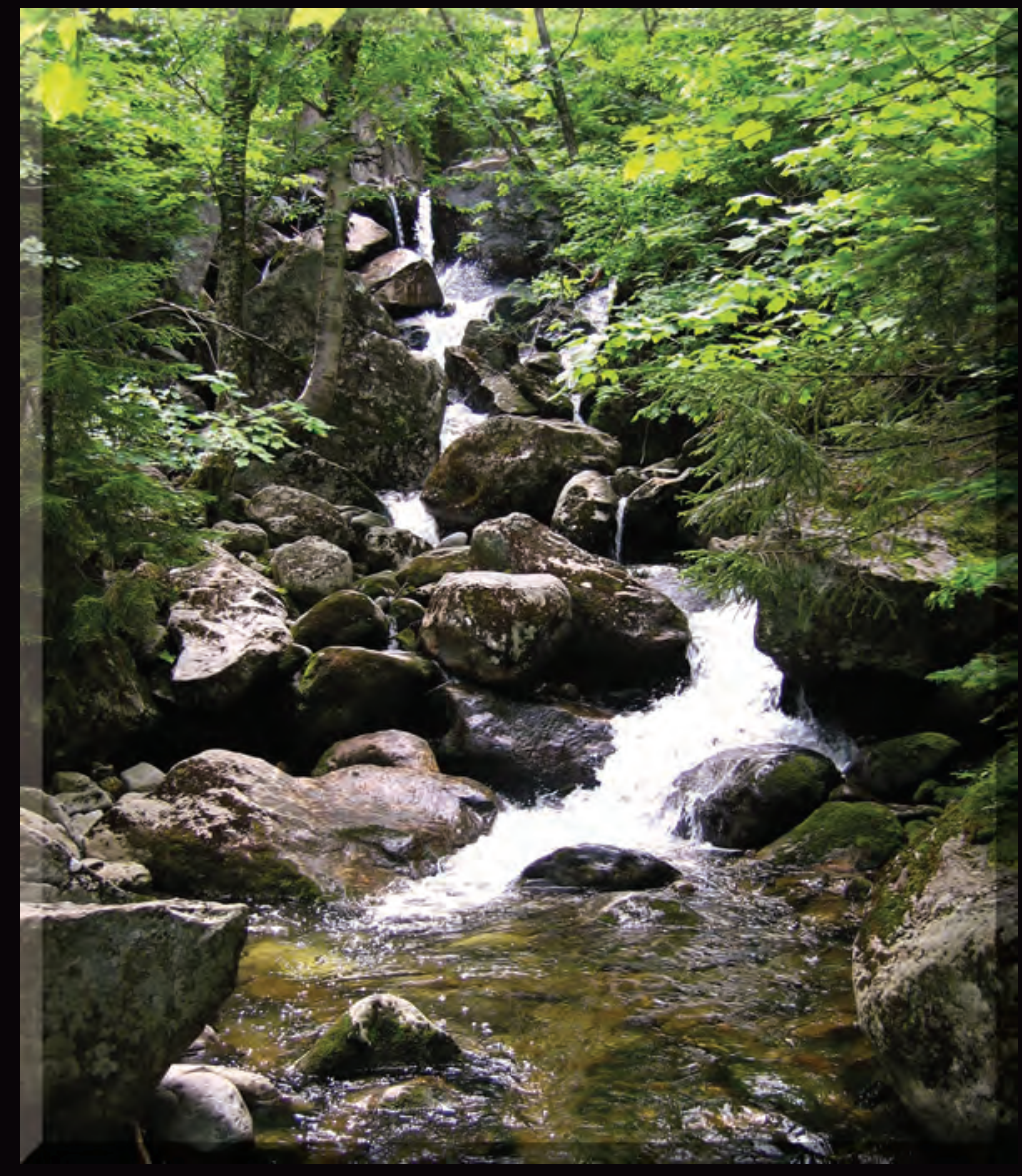

Scientific Investigations Report 2011-5151

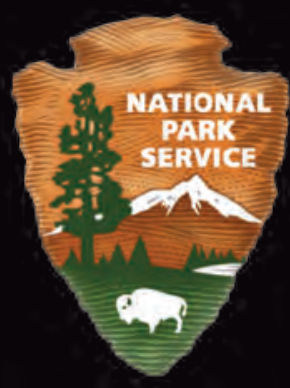


Front cover. Bumpus Brook above Stairs Falls on the Howker Ridge Trail of Mount Madison in Coos County, New Hampshire. (Photograph published with permission from Nancy Gaudreau)

Back cover. Appalachian National Scenic Trail in the Pisgah National Forest, east of Roan Highlands, North Carolina.

(Photograph published with permission from Nancy Gaudreau) 


\section{Characterization of Major-Ion Chemistry and Nutrients in Headwater Streams Along the Appalachian National Scenic Trail and Within Adjacent Watersheds, Maine to Georgia}

By Denise M. Argue, Jason P. Pope, and Fred Dieffenbach

Prepared in cooperation with the National Park Service

Scientific Investigations Report 2011-5151 


\section{U.S. Department of the Interior \\ KEN SALAZAR, Secretary \\ U.S. Geological Survey \\ Marcia K. McNutt, Director}

U.S. Geological Survey, Reston, Virginia: 2012

For more information on the USGS - the Federal source for science about the Earth, its natural and living resources, natural hazards, and the environment, visit http://www.usgs.gov or call 1-888-ASK-USGS.

For an overview of USGS information products, including maps, imagery, and publications, visit http://www.usgs.gov/pubprod

To order this and other USGS information products, visit http://store.usgs.gov

Any use of trade, product, or firm names is for descriptive purposes only and does not imply endorsement by the U.S. Government.

Although this report is in the public domain, permission must be secured from the individual copyright owners to reproduce any copyrighted materials contained within this report.

Suggested citation:

Argue, D.M., Pope, J.P., and Dieffenbach, Fred, 2012, Characterization of major-ion chemistry and nutrients in headwater streams along the Appalachian National Scenic Trail and within adjacent watersheds, Maine to Georgia: U.S. Geological Survey Scientific Investigations Report 2011-5151, 63 p., plus CD-ROM. (Also available at http://pubs.usgs.gov/sir/2011/5151.) 


\section{Acknowledgments}

The authors thank Dean Tucker, National Park Service (NPS) for extracting the water-quality data and sampling sampling-site information from the U.S. Geological Survey's National Water Information System database and from the U.S. Environmental Protection Agency's STOrage and RETrieval databases (including the Legacy STORET database) for the area within a 20-mile buffer about the Appalachian Trail. A wide variety of supporting geospatial data were supplied by Casey Reese (NPS) and Matt Robinson (NPS). The authors also thank the individuals who were the stewards of the multiple additional datasets obtained for this project for providing these data to the authors and assisting the authors with their proper use. The authors recognize that data provided by the Coweeta Long Term Ecological Research (LTER) program were collected in the course of research supported by the National Science Foundation (NSF) award DEB-0823293 from the Long Term Ecological Research Program to the Coweeta LTER Program at the University of Georgia and that opinions, findings, conclusion, or recommendations expressed in this report do not necessarily reflect the views of the National Science Foundation or the University of Georgia. The authors recognize that the long-term streamwater chemistry data from Hubbard Brook LTER were provided by Gene Likens through funding supported from the NSF, including LTER and Long Term Research in Environmental Biology programs and the Andrew W. Mellon Foundation. 
THIS PAGE INTENTIONALLY LEFT BLANK 


\section{Contents}

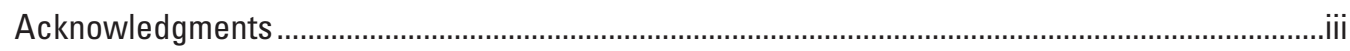

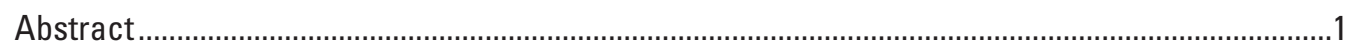

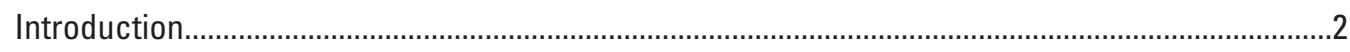

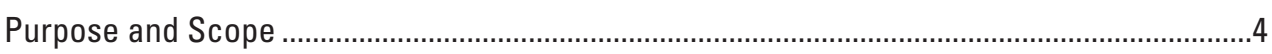

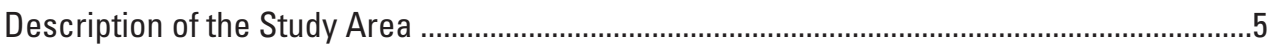

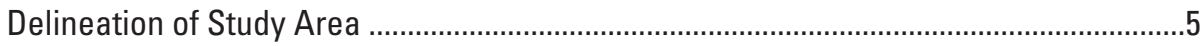

Geology

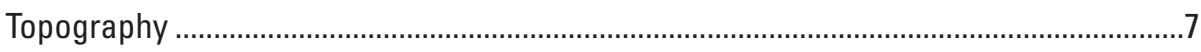

Precipitation and Temperature .....................................................................................

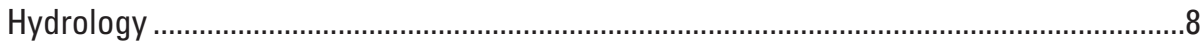

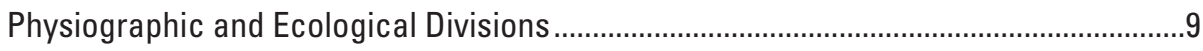

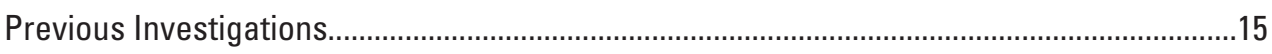

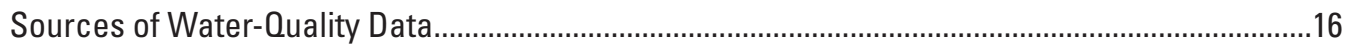

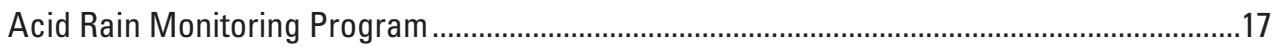

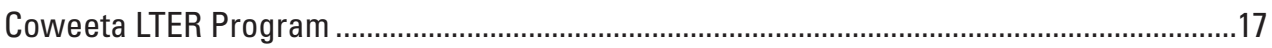

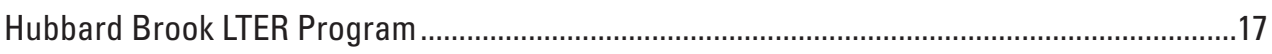

Delaware Water Gap National Recreation Area ……........................................................17

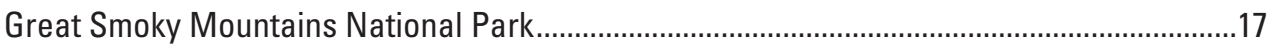

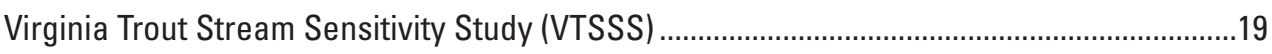

White Mountain National Forest........................................................................................19

Environmental Monitoring and Assessment Program (EMAP) ...........................................19

Temporally Integrated Monitoring of Ecosystems and Long Term Monitoring Program (TIME/LTM) .................................................................................................19

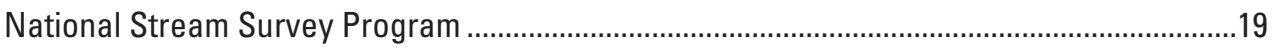

Wadeable Stream Assessment Program...........................................................................19

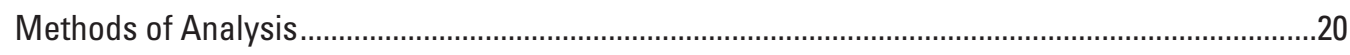

Quality Assurance and Compilation of Water-Quality Data ..................................................20

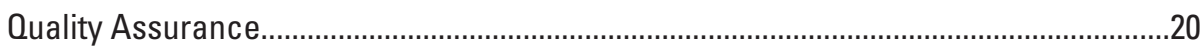

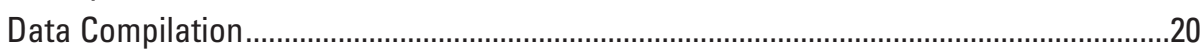

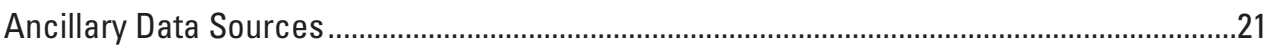

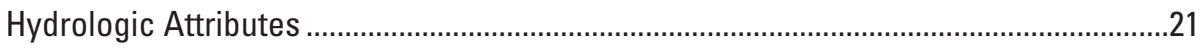

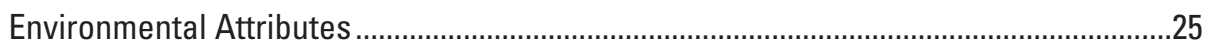

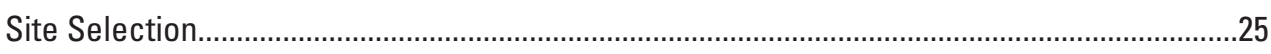

Criteria for Selection of Nonadjacent Sampling Sites.....................................................25

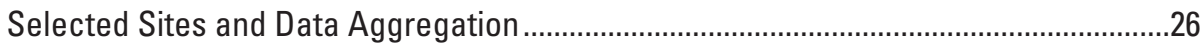

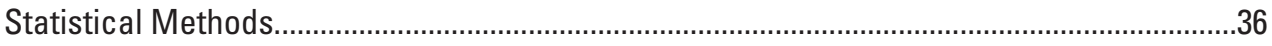

Characterization of Selected Field Properties, Major-Ion Chemistry, Acid Neutralizing

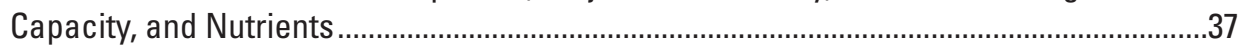

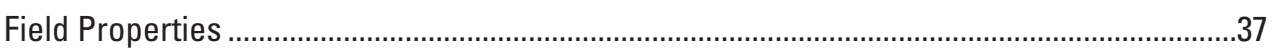

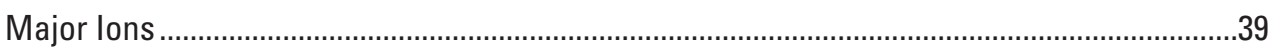

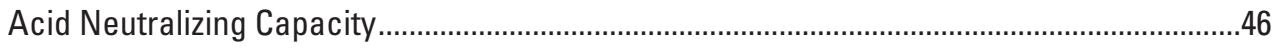

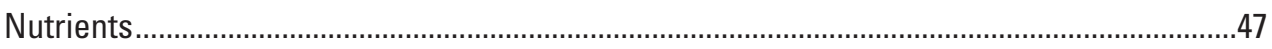


Effects of Environmental Attributes on Water Quality................................................................4

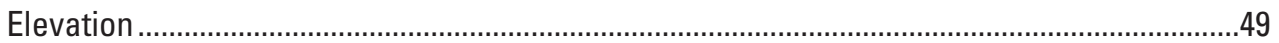

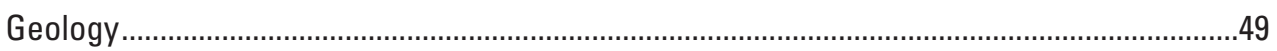

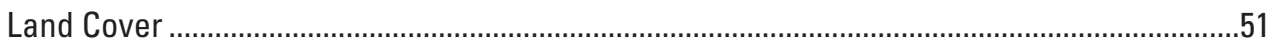

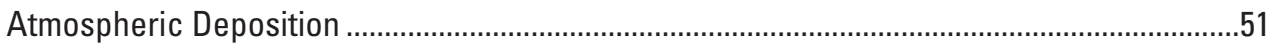

Implications of Using Available Data and Considerations for Future Monitoring.............................55

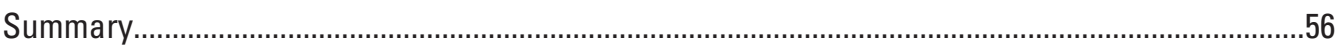

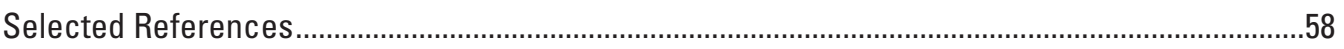

Appendix 1. Ancillary and Water-Quality Variable Definitions and Catchment Data

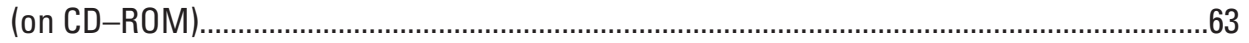

\section{Figures}

1. Map showing location of the Appalachian National Scenic Trail and study area ............3

2. Photograph showing the Appalachian National Scenic Trail north of Roanoke,

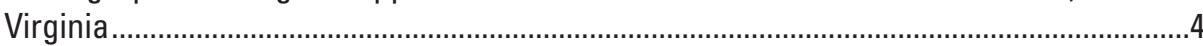

3. Map showing the percentage of forested land cover in the study area..........................6

4. Photograph showing the Appalachian National Scenic Trail passing through an open field on Cross Mountain near Shady Valley, Tennessee.

5. Photograph showing the Appalachian National Scenic Trail on Franconia Ridge, near Franconia, New Hampshire

6. Photograph showing a first-order stream, typical of the high-elevation streams that are crossed by the Appalachian National Scenic Trail.

7. Map showing U.S. Forest Service ecological sections (ecosections) that intersect the study area

8. Photograph showing the Appalachian National Scenic Trail passing over Little Hump in North Carolina through the region known as the "balds".

9. Map showing hydrologic subregions that intersected and were used as geographic subdivisions of the study area

10. Schematic diagram showing examples of the nested relation of National Hydrography Dataset Plus catchments with larger delineated hydrographic units such as subwatersheds, and drainage areas defined for a set of nested catchments .24

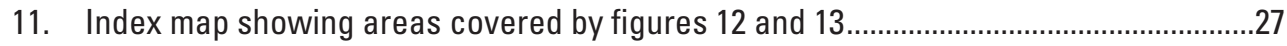

12. Maps showing first- and second-order catchments from the National Hydrography Dataset Plus that are adjacent to the Appalachian National Scenic Trail and were used to characterize physical attributes of the trail environment from $A$, Maine to Vermont, $B$, Massachusetts to Maryland, $C$, Maryland to Virginia, and $D$, Virginia to Georgia.

13. Maps showing the spatial distribution of and the number of sampling sites in National Hydrography Dataset Plus catchments used in the level 1 inventory of firstand second-order streams along the Appalachian National Scenic Trail, $A$, Maine to Vermont, $B$, Massachusetts to Maryland, $C$, Maryland to Virginia, and $D$, Virginia to Georgia

14. Boxplots showing comparisons of concentrations of $A, \mathrm{pH}, B$, specific conductance, $C$, acid neutralizing capacity, $D$, calcium, $E$, magnesium, $F$, sodium, $G$, potassium, $H$, sulfate, $I$, chloride, J, nitrate, $K$, ammonia, $L$, total nitrogen, and $M$, total phosphorus, by U.S. Forest Service ecological sections (ecosections), from catchments that contain selected first- and second-order streams along the Appalachian National Scenic Trail 
15. Map showing major geologic units within the study area

16. Boxplots showing comparison of concentrations, by major geologic groups, of $A, \mathrm{pH}, B$, specific conductance, and $C$, acid neutralizing capacity from catchments that contained selected first- and second-order streams along the Appalachian National Scenic Trail

17. Maps of 1994 annual wet-deposition estimates for $A$, sulfate and $B$, nitrate for the eastern United States, including the study area

18. Boxplots showing wet-deposition estimates from 1994 of $A$, sulfate and $B$, nitrate by U.S. Forest Service ecological sections (ecosections) for all first and second order catchments in the study area.

\section{Tables}

1. Description of landscapes, geology, and primary land cover for physiographic provinces and U.S. Forest Service ecological sections..

2. Appalachian National Scenic Trail level 1 inventory of data sources used, project acronym, number of sampling sites, number of records, and the period of record for the water-quality data initially compiled.

3. Types and sources of ancillary data used in this study

4. Threshold values, by subregion, of selected physical attributes used to screen nonadjacent sampling sites for inclusion in the water-quality summary of selected sampling sites along the Appalachian National Scenic Trail......

5. Summary statistics of selected physical attributes, by U.S. Forest Service ecological sections (ecosections), from catchments that contain selected sampling sites along the Appalachian National Scenic Trail

6. Summary statistics of concentrations of selected water-quality constituents from catchments that contain selected sampling sites along the Appalachian National Scenic Trail.

7. Water temperature and dissolved oxygen concentrations by U.S. Forest Service ecological sections (ecosections) and by season from selected sampling sites along the Appalachian National Scenic Trail

8. Summary statistics of selected water-quality constituents by U.S. Forest Service ecological sections (ecosections) from catchments that contain selected sampling sites in headwater streams along the Appalachian National Scenic Trail.

9. Comparison among U.S. Forest Service ecological sections (ecosections) of the percentages of catchments with acid neutralizing capacity classified as acidic, sensitive, or insensitive

10. Comparison of median catchment concentrations of nutrients and the percentages of median concentrations greater than estimated national background concentrations from selected sampling sites along the Appalachian National Scenic Trail.

11. Comparison, by nutrient ecoregion, of median catchment concentrations of total nitrogen and total phosphorus and the percentages of median catchment concentrations greater than U.S. Environmental Protection Agency's nutrient criteria from selected sampling sites along the Appalachian National Scenic Trail

12. Rho values from Spearman correlations of the elevations of catchments and the percentages of developed and agricultural land cover with concentrations of selected water-quality constituents in catchments that contained selected sampling sites along the Appalachian National Scenic Trail

13. Rho values from Spearman correlations of elevation with selected environmental attributes of catchments that contain selected sampling sites along the Appalachian National Scenic Trail 


\section{Conversion Factors, Abbreviations, and Acronyms}

\begin{tabular}{lcl}
\hline \multicolumn{1}{c}{ Multiply } & By & \multicolumn{1}{c}{ To obtain } \\
\hline inch (in.) & Length & \\
foot (ft) & 2.54 & centimeter $(\mathrm{cm})$ \\
mile (mi) & 0.3048 & meter $(\mathrm{m})$ \\
\hline \multicolumn{3}{c}{ Area } \\
\hline square mile $\left(\mathrm{mi}^{2}\right)$ & 1.609 & kilometer $(\mathrm{km})$ \\
square mile $\left(\mathrm{mi}^{2}\right)$ & 259.0 & hectare $(\mathrm{ha})$ \\
\hline
\end{tabular}

Temperature in degrees Celsius $\left({ }^{\circ} \mathrm{C}\right)$ may be converted to degrees Fahrenheit $\left({ }^{\circ} \mathrm{F}\right)$ as follows:

$$
{ }^{\circ} \mathrm{F}=\left(1.8 \times^{\circ} \mathrm{C}\right)+32
$$

Vertical coordinate information is referenced to the North American Vertical Datum of 1988 (NAVD 88).

Horizontal coordinate information is referenced to the North American Datum of 1983 (NAD 83).

Specific conductance is given in microsiemens per centimeter at 25 degrees Celsius $(\mu \mathrm{S} / \mathrm{cm}$ at $\left.25^{\circ} \mathrm{C}\right)$.

Concentrations of chemical constituents in water are given in milligrams per liter $(\mathrm{mg} / \mathrm{L})$,

micrograms per liter $(\mu \mathrm{g} / \mathrm{L})$, micromoles per liter $(\mu \mathrm{mol} / \mathrm{L})$, and microequivalents per liter $(\mu \mathrm{eq} / \mathrm{L})$.

Concentrations of chemical constituents in wet-atmospheric deposition are given in kilograms per hectare $(\mathrm{kg} / \mathrm{ha})$.

\section{Acronyms}

$\begin{array}{ll}\text { ANC } & \text { acid neutralizing capacity } \\ \text { ATC } & \text { Appalachian Trail Conservancy } \\ \text { CAAA } & \text { Clean Air Act Amendments of 1990 } \\ \text { EMAP } & \text { Environmental Monitoring and Assessment Program } \\ \text { LTER } & \text { Long Term Ecological Research } \\ \text { LTM } & \text { Long Term Monitoring } \\ \text { NADP } & \text { National Atmospheric Deposition Program } \\ \text { NHD } & \text { National Hydrography Dataset } \\ \text { NPS } & \text { National Park Service } \\ \text { NSF } & \text { National Science Foundation } \\ \text { NWIS } & \text { National Water Information System } \\ \text { STORET } & \text { STORage and RETrieval database operated by the U.S. Environmental } \\ \text { TIME } & \text { Protection Agency } \\ \text { USEPA } & \text { Temporally Integrated Monitoring of Ecosystems } \\ \text { USFS } & \text { U.S. Environmental Protection Agency } \\ \text { USGS } & \text { U.S. Forest Service } \\ \text { VTSSS } & \text { U.S. Geological Survey } \\ & \text { Virginia Trout Stream Sensitivity Study }\end{array}$




\title{
Characterization of Major-Ion Chemistry and Nutrients in Headwater Streams Along the Appalachian National Scenic Trail and Within Adjacent Watersheds, Maine to Georgia
}

\author{
By Denise M. Argue', Jason P. Pope', and Fred Dieffenbach ${ }^{3}$
}

\section{Abstract}

An inventory of water-quality data on field parameters, major ions, and nutrients provided a summary of water quality in headwater (first- and second-order) streams within watersheds along the Appalachian National Scenic Trail (Appalachian Trail). Data from 1,817 sampling sites in 831 catchments were used for the water-quality summary. Catchment delineations from NHDPlus were used as the fundamental geographic units for this project. Criteria used to evaluate sampling sites for inclusion were based on selected physical attributes of the catchments adjacent to the Appalachian Trail, including stream elevation, percentage of developed land cover, and percentage of agricultural land cover.

The headwater streams of the Appalachian Trail are generally dilute waters, with low $\mathrm{pH}$, low acid neutralizing capacity (ANC), and low concentrations of nutrients. The median $\mathrm{pH}$ value was slightly acidic at 6.7 ; the median specific conductance value was 23.6 microsiemens per centimeter, and the median ANC value was 98.7 milliequivalents per liter ( $\mu \mathrm{eq} / \mathrm{L})$. Median concentrations of cations (calcium, magnesium, sodium, and potassium) were each less than 1.5 milligrams per liter $(\mathrm{mg} / \mathrm{L})$, and median concentrations of anions (bicarbonate, chloride, fluoride, sulfate, and nitrate) were less than $10 \mathrm{mg} / \mathrm{L}$.

Differences in water-quality constituent levels along the Appalachian Trail may be related to elevation, atmospheric deposition, geology, and land cover. Spatial variations were summarized by ecological sections (ecosections) developed by the U.S. Forest Service. Specific conductance, pH, $\mathrm{ANC}$, and concentrations of major ions (calcium, chloride, magnesium, sodium, and sulfate) were all negatively correlated with elevation. The highest elevation ecosections

\footnotetext{
${ }^{1}$ U.S. Geological Survey.

${ }^{2}$ U.S. Geological Survey.

${ }^{3}$ National Park Service.
}

(White Mountains, Blue Ridge Mountains, and Allegheny Mountains) had the lowest $\mathrm{pH}, \mathrm{ANC}$, and concentrations of major ions. The lowest elevation ecosections (Lower New England and Hudson Valley) generally had the highest $\mathrm{pH}$, $\mathrm{ANC}$, and concentrations of major ions. The geology in discrete portions of these two ecosections was classified as containing carbonate minerals which has likely influenced the chemical character of the streamwater. Specific conductance, $\mathrm{pH}, \mathrm{ANC}$, and concentrations of major ions (calcium, chloride, magnesium, sodium, and sulfate) were all positively correlated with percentages of developed and agricultural land uses at the lower elevations of the central region of the Appalachian Trail (including the Green-Taconic-Berkshire Mountains, Lower New England, Hudson Valley, and Northern Ridge and Valley ecosections). The distinctly different chemical character of the streams in the central sections of the Appalachian Trail is likely related to the lower elevations, the presence of carbonate minerals in the geology, higher percentages of developed and agricultural land uses, and possibly the higher inputs of sulfate and nitrate from atmospheric deposition.

Acid deposition of sulfate and nitrate are important influences on the acid-base chemistry of the surface waters of the Appalachian Trail. Atmospheric deposition estimates are consistently high (more than 18 kilograms per hectare ( $\mathrm{kg} / \mathrm{ha}$ ) for sulfate, and more than $16 \mathrm{~kg} / \mathrm{ha}$ for nitrate) at both the highest and lowest elevations. However, the lowest elevation (Green-Taconic-Berkshire Mountains, Lower New England, Hudson Valley, Northern Glaciated Allegheny Plateau, and Northern Ridge and Valley ecosections) included the largest spatial area of sustained high estimates of atmospheric deposition.

Calcium-bicarbonate was the most frequently calculated water type in the Lower New England and Hudson Valley ecosections. In the northern and southern sections of the Appalachian Trail mix-cation water types were most prevalent and sulfate was the predominate anion. The predominance of the sulfate anion in the surface waters of the northern and southern ecosections likely reflects the influence of sulfate deposition. Although the central portion of the Appalachian Trail has the largest spatial area of high atmospheric acid 
deposition, the lower ionic strength waters in the northern and southern ecosections of the Appalachian Trail may have been more adversely affected by acid deposition.

The low ionic strength of the streams in the White Mountains, Blue Ridge Mountains, and Allegheny Mountains ecosections makes parts of these regions susceptible to seasonal or event-driven episodic acidification, which can be detrimental to health of aquatic and terrestrial ecosystems. Median catchment ANC values were classified into three groups - acidic, sensitive, and insensitive. The White Mountains, Blue Ridge Mountains, and Allegheny Mountains ecosections included the highest frequency of catchments classified as acidic or sensitive. More than 56 percent of the catchments from the White Mountains ecosection were classified as sensitive to acidic inputs. In the Blue Ridge ecosection, 1.6 percent of the catchments were classified as acidic, and 38.2 percent of the catchments were classified as sensitive to acidic inputs. In the Allegheny Mountains ecosection, 17.6 percent of the catchments were classified as acidic, and 29.4 percent of the catchments were classified as sensitive to acidic inputs.

Median concentrations of nitrogen species were less than $0.4 \mathrm{mg} / \mathrm{L}$, and median concentrations of total phosphorus were less than $0.02 \mathrm{mg} / \mathrm{L}$ along the Appalachian Trail. A comparison of median catchment concentrations of nutrients to estimated national background concentrations demonstrated that concentrations along the Appalachian Trail are generally lower. A comparison of median concentrations of total nitrogen and total phosphorus to the U.S. Environmental Protection Agency's (USEPA) nutrient criteria for the Eastern U.S. ecoregions showed that the concentrations of total nitrogen in the northern section of the Appalachian Trail were generally higher than the USEPA criterion. Similarly, median concentrations of total phosphorus in the southern regions of the Appalachian Trail were approximately twice as high as USEPA criteria. Sections of the Appalachian Trail are adjacent to modest amounts of agricultural and developed land areas. These nonforested land areas may be contributing to the percentage of catchments in which concentrations of total nitrogen and total phosphorus are higher than USEPA nutrient ecoregion criteria.

\section{Introduction}

The level 1 inventory is a process used by the Water Resources Division of the National Park Service (NPS), to provide descriptive water-quality information for key water resources at NPS units throughout the United States. The Appalachian National Scenic Trail (Appalachian Trail) is a unit of the National Park System that extends along almost the entire Appalachian Mountain range in the Eastern United States (fig. 1). The Appalachian Trail passes from Maine to Georgia through 14 states, 6 national parks, 8 national forests, 1 national wildlife refuge, and a variety of lands owned by federal, state, local, and nonprofit organizations (National Park Service, 2008). The Appalachian Trail is administered through a cooperative management system in which responsibilities are shared among the NPS, the U.S. Forest Service (USFS), the nonprofit Appalachian Trail Conservancy (ATC), and other organizations. More than 99 percent of the Appalachian Trail lies on protected land (National Park Service, 2008), and the trail traverses a wide variety of landscapes characteristic of the Appalachian Mountains.

The Appalachian Trail was originally conceived by Benton MacKaye, an early 20th Century conservationist, as a footpath (fig. 2) that linked a series of small isolated communities (MacKaye, 1921). While some of MacKaye's original visions did not materialize, the trail itself did come together as a footpath that provides hikers the ability to traverse a largely intact wilderness located along the crest of the Appalachian Mountains. In recent years, as natural systems in the United States have been increasingly affected by human activities, including urbanization, pollution, habitat fragmentation, and invasive species, there has been an increased awareness and appreciation of the Appalachian Trail for its value as an intact corridor of protected natural lands and as a study area for research on the effects of human disturbance and variations in climate over time on natural systems (Shriver and others, 2005).

The quality of water resources along the Appalachian Trail were identified by the NPS as a critical measure of the environmental health of the Appalachian Trail (Shriver, 2005). A fundamental understanding of the natural-resource conditions along the Appalachian Trail is essential for the NPS to manage Appalachian Trail water resources in a way that is consistent with its mission. Water resources along the Appalachian Trail include streams, rivers, lakes, ponds, seeps, springs, wetlands, and wells. The form, structure, and occurrence of these water resources vary considerably, and their characteristics and occurrence may depend on the geology, climate, and the terrestrial ecological systems in particular areas. The water resources along the Appalachian Trail serve many uses, providing a source of drinking water for hikers, visitors, and wildlife; providing recreational, scenic and aesthetic value; habitat for plants and animals; and a source of water for downstream uses, such as public water supplies, fisheries, and hydropower generation.

An assessment of the quality of water resources along the Appalachian Trail has not been previously undertaken, although a variety of studies have been performed within specific regions and individual park units through which the Appalachian Trail passes. The current review conducted by the U.S. Geological Survey (USGS), in cooperation with the NPS, comprises a level 1 inventory of available water-quality data (1923-2009) along the Appalachian Trail. The NPS requested the USGS to perform a level 1 water-quality inventory of the Appalachian Trail to enable NPS to develop baseline waterquality information for key water resources that are defined as those waters that are essential to the central cultural, historical, or natural-resource-management themes of the park or 


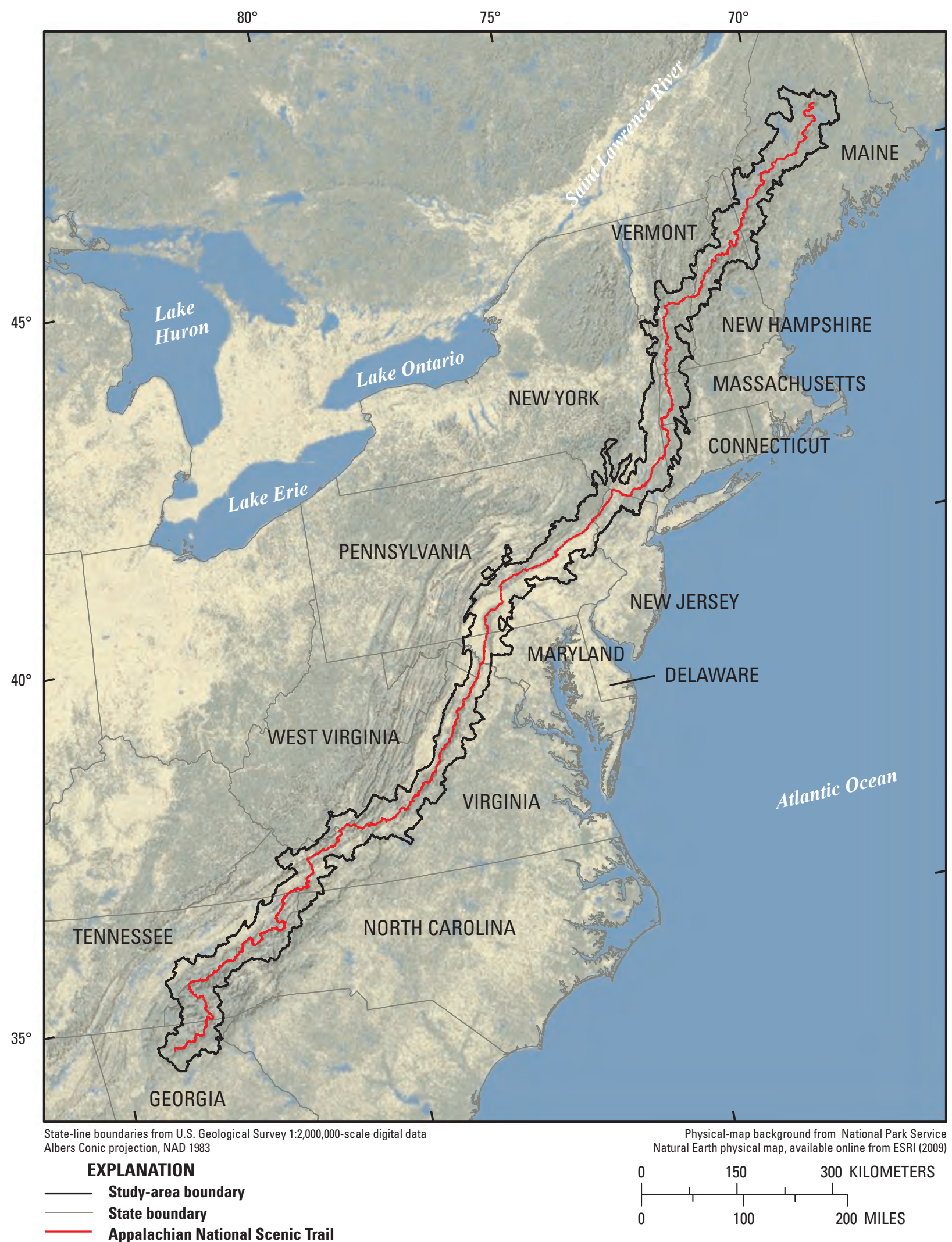

Figure 1. Location of the Appalachian National Scenic Trail and study area. 


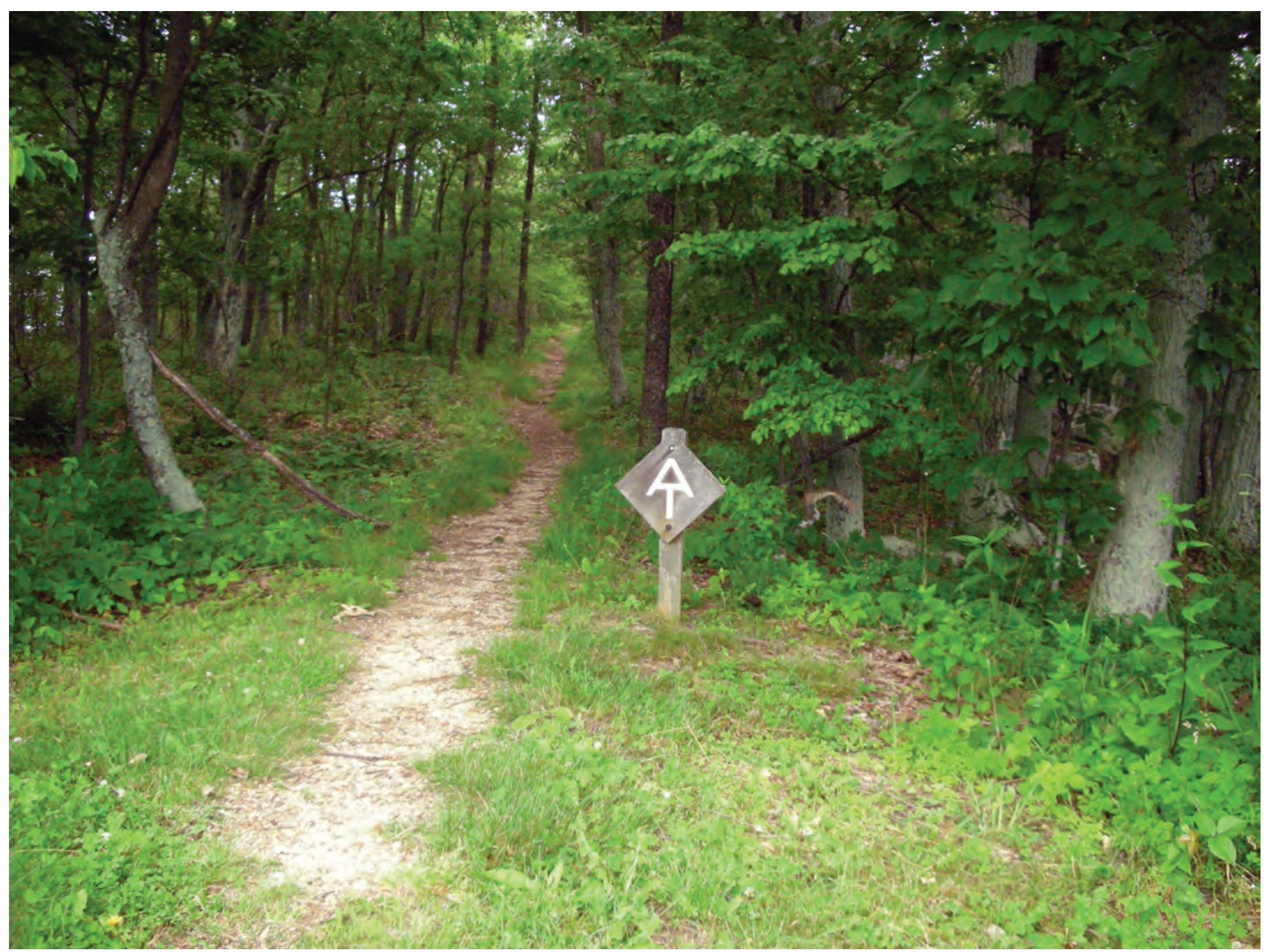

Figure 2. The Appalachian National Scenic Trail (AT) north of Roanoke, Virginia. Symbol on the sign is an emblem for AT. (Photograph courtesy of Joseph Ayotte, U.S. Geological Survey)

that provide habitats for threatened or endangered plants and animals. The focus of this report is on headwater streams that represent one common, or 'characteristic' water resource that is key along the Appalachian Trail. This information will enhance the ability of NPS to manage park resources, could have direct relevance for future resource-monitoring activities, and may serve as a foundation from which changes in water quality could be assessed over time.

\section{Purpose and Scope}

This report summarizes the objectives, methods, and results of analyses of water-quality data compiled by the USGS for headwater streams (classified as first- and secondorder streams in the Strahler stream-order system) along and near the Appalachian Trail from Maine to Georgia. Specific objectives of this project include (1) compiling waterquality data collected along or near the Appalachian Trail;
(2) determining the spatial coverage of water-quality data; (3) developing a method by which data could be screened to determine suitability for inclusion in water-quality summaries; (4) providing summary statistics of the concentrations of selected constituents typically used to describe basic water chemistry; (5) describing natural and anthropogenic factors that may explain the observed variability in water quality; and (6) evaluating how data can help guide future water-qualitymonitoring considerations. The parameters and constituents selected for analysis in this report include $\mathrm{pH}$, specific conductance, dissolved oxygen, water temperature, acid neutralizing capacity (ANC), bicarbonate, calcium, chloride, fluoride, magnesium, potassium, silica, sodium, sulfate, ammonia, nitrate, total nitrogen, and total phosphorus. The focus is on basic chemical quality of headwater streams and the report does not include data on microbiological characteristics, trace elements, and other constituents that are commonly related to drinking water quality. 
In an attempt to compile the most extensive inventory of water-quality data that characterize headwater streams along and nearby the Appalachian Trail, a method for incorporating sampling sites not adjacent to the Appalachian Trail (hereafter referred to as nonadjacent) was developed. The developed methodology for selecting nonadjacent sampling sites helped to ensure that the environmental setting of the selected nonadjacent sampling sites was representative of the Appalachian Trail environment and therefore appropriate for inclusion in this water-quality characterization. In this report, the term 'Appalachian Trail environment' (not spatially defined) is used to refer to the general characteristics of the landscape features and surrounding area and resources in the immediate vicinity of the Appalachian Trail.

\section{Description of the Study Area}

The Appalachian Trail is an approximately 2,175-mi-long footpath that follows the crest of the Appalachian Mountain range in the eastern United States. From its northern end in central Maine to its southern end in northern Georgia, the Appalachian Trail passes through 14 states, including New Hampshire, Vermont, Massachusetts, Connecticut, New York, New Jersey, Pennsylvania, Maryland, West Virginia, Virginia, North Carolina, and Tennessee (Shriver and others, 2005). The Appalachian Trail passes through a wide variety of landscapes representative of the Appalachian Mountains, including topographic classes such as high mountain ridges and peaks, rolling foothills, plateaus, and river valleys.

Land along the Appalachian Trail is most commonly forested (fig. 3), with occasional open grassy (fig. 4) and rocky areas (fig. 5), and intermittent agricultural and developed areas (Dieffenbach, 2011). Farmland used for both row crops and pasture is also adjacent to many parts of the Appalachian Trail, but agricultural land is much more common in the mid-Atlantic than in other areas. The Appalachian Trail traverses land that is typically sparsely populated and relatively undeveloped, but it also passes near some large population centers, particularly in New York and Virginia. The Appalachian Trail actually passes through thirteen cities and towns defined as Urbanized Areas or Urban Clusters by the U.S. Census, including the New York-Newark Urbanized Area in New York and New Jersey, the AllentownBethlehem Urbanized Area in Pennsylvania, and the Roanoke Urbanized Area in Virginia (U.S. Census, 2003). Overall, the Appalachian Trail constitutes a protected corridor of relatively undeveloped land where important natural ecosystems of the Appalachian highlands are preserved.

Land along the Appalachian Trail is subject to many of the same environmental problems that threaten natural areas in other places. Threats to the health of the Appalachian Trail environment include atmospheric ozone; atmospheric deposition of sulfur, nitrogen, and mercury; impaired visibility; pressure on rare and endangered wildlife and vegetation; invasive species; climate change and variability; and changes in land use; particularly from encroaching development (Shriver and others, 2005).

\section{Delineation of Study Area}

The Appalachian Trail is delineated and protected by a right-of-way corridor typically extending about $500 \mathrm{ft}$ on either side of the footpath. While the Appalachian Trail can be most narrowly defined as the area within this 1000 -ft-wide corridor, a broader area of interest was needed to capture as much relevant water-quality data as possible for a level 1 assessment of the quality of water resources in the Appalachian Trail environment. In consultation with the NPS, a discrete study area for this investigation was defined on the basis of hydrologic boundaries to provide a geographic scope with hydrologic relevance to the Appalachian Trail. This study area was specifically defined as the intersections of the boundaries of watersheds (10-digit hydrologic units) (U.S. Department of Agriculture, 2005) not more than $5 \mathrm{mi}$ from the Appalachian Trail corridor. This area of interest is known as the HUC10 shell (Dieffenbach, 2011). The HUC10 shell, referred to as study area in this report, incorporates an area that is approximately $41,779 \mathrm{mi}^{2}$ and extends approximately $15 \mathrm{mi}$ on either side of the Appalachian Trail; it is much wider in some places and narrower in others owing to the different sizes of the watersheds composing the boundary (fig. 1).

\section{Geology}

The distinctive rolling-to-mountainous topography of the Appalachian Mountains is the product of the geologic development of this region. Repeated mountain-building episodes resulting from continental collisions, followed by hundreds of millions of years of weathering and erosion, have shaped the Appalachian Mountains to its current conformations. This complex geologic history has resulted in rocks ranging in age from billions of years to about 140 million years (National Park Service, 2008). The geology includes a range of rock types, from folded and faulted sedimentary rocks such as limestone, sandstone, and shale, to metamorphic rocks such as schist and gneiss, to extensive intrusive rocks such as granites, as well as localized volcanic rocks. North of central Pennsylvania, continental glaciation during the Pleistocene Era further sculpted the landscape, leaving behind features characteristic of glacial environments, including many ponds (National Park Service, 2008). The underlying geology is important because it is a fundamental aspect of the region: variations in the weathering rates of differing types of rocks, combined with geologic features such as faults and folds, have a substantial effect on drainage patterns, slopes, elevations, and many other topographic features. Additionally, variations in mineralogy may substantially affect surface-water chemistry, especially in smaller watersheds where base flow may be dominant. 


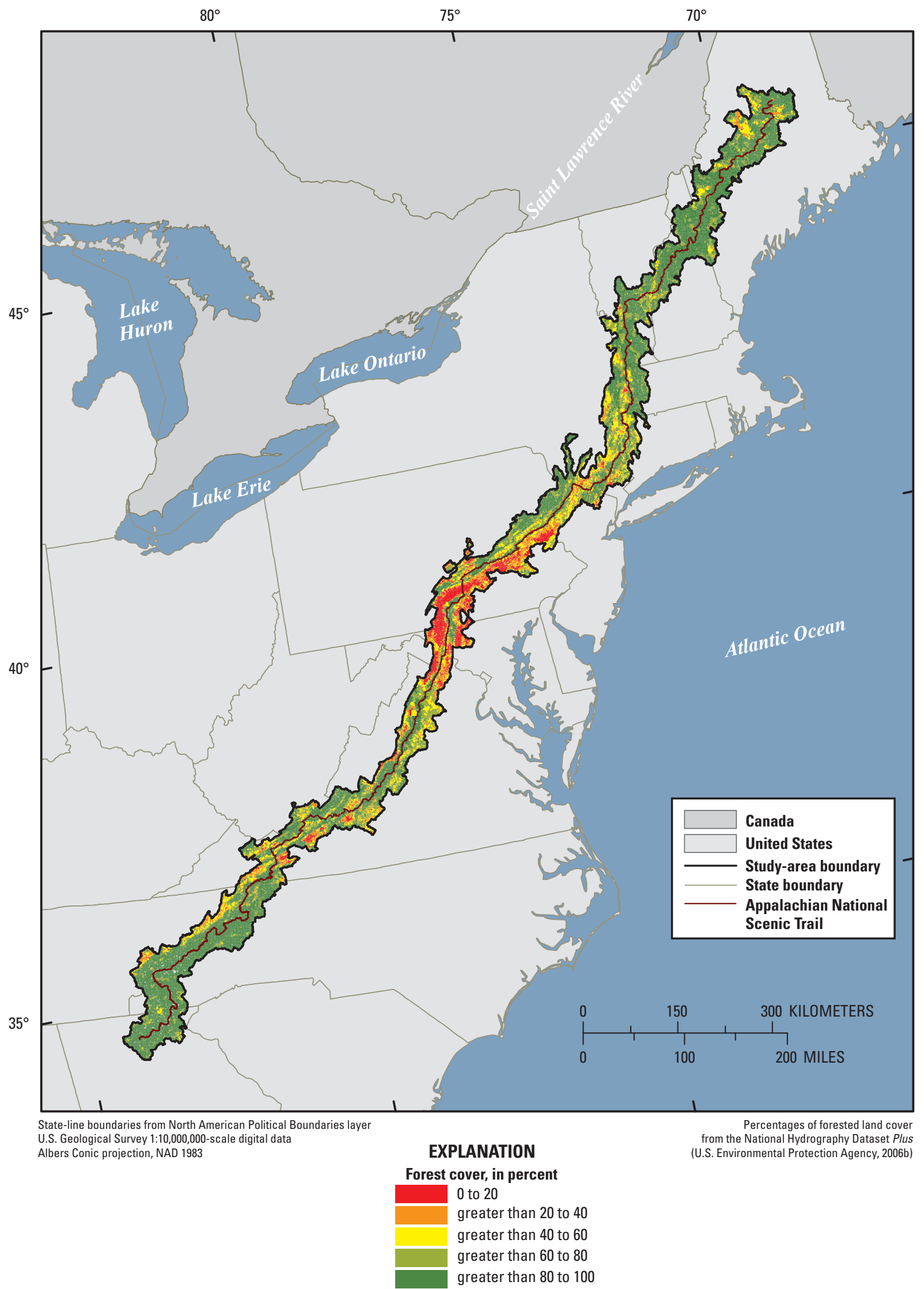

Figure 3. The percentage of forested land cover in the study area. 


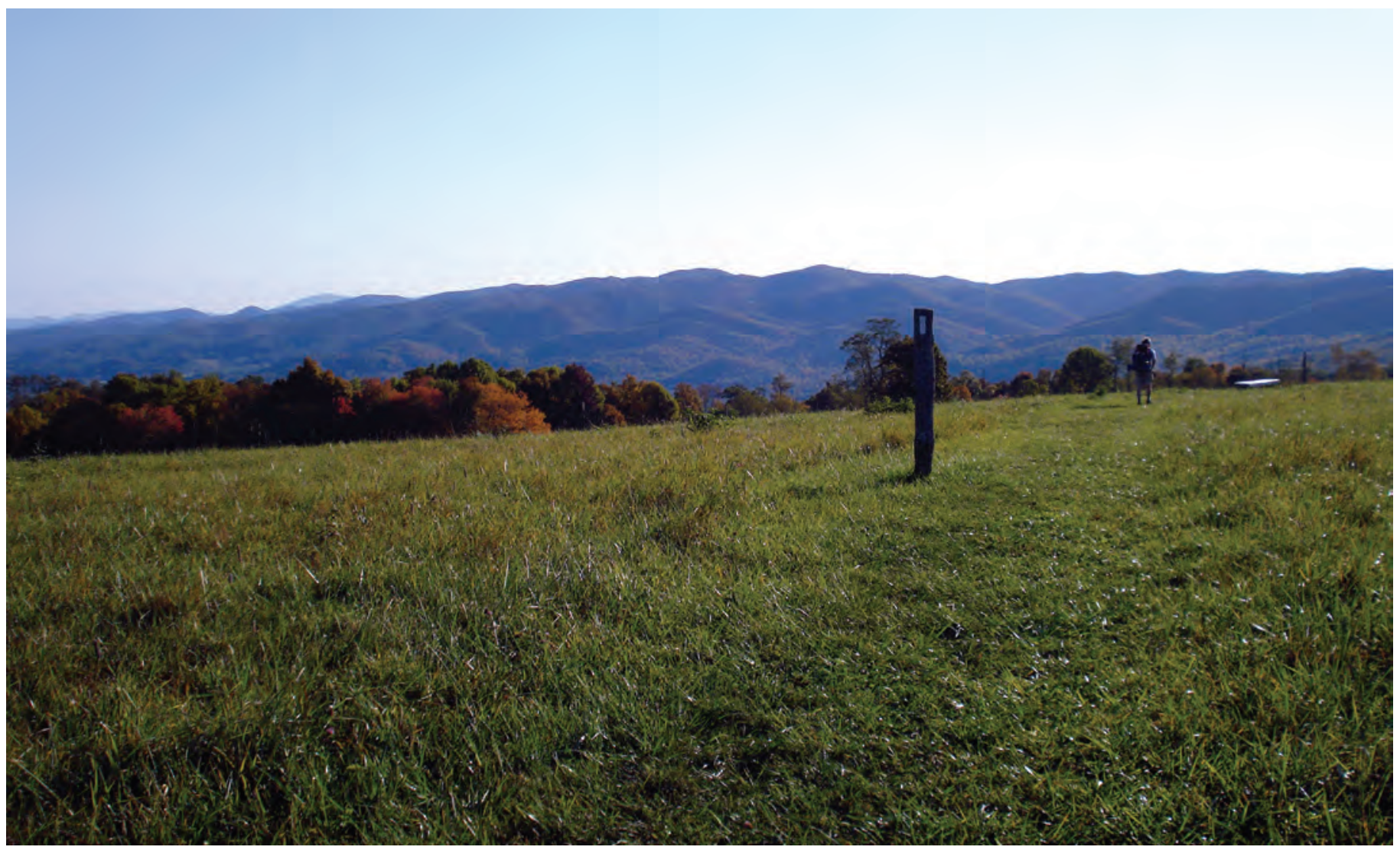

Figure 4. The Appalachian National Scenic Trail passing through an open field on Cross Mountain near Shady Valley, Tennessee. (Photograph published by permission of Nancy Gaudreau)

\section{Topography}

High elevations and steep slopes generally characterize the relief of the land in the immediate vicinity of the Appalachian Trail. Considerable variation in elevation exists along the Appalachian Trail, ranging from $124 \mathrm{ft}$ above sea level where it crosses the Hudson River at Bear Mountain, New York to 6,643 ft at Clingmans Dome in Tennessee (National Park Service, 2008). The highest elevations and steepest slopes are generally in northern New England and in the southern Appalachians, whereas the lowest elevations are in the states of New York, New Jersey, Pennsylvania, and Maryland. Along the Appalachian Trail, the high ridges of the Appalachian Mountains are occasionally dissected by major river valleys such as the valleys of the Hudson, Susquehanna, and Potomac, which are characterized by flat to rolling terrain.

\section{Precipitation and Temperature}

The climate in the vicinity of the Appalachian Trail is highly variable owing to the substantial range in latitude, elevation, and prevailing weather patterns. Cool summers and very cold winters are common in the northern areas around the Appalachian Trail, whereas hot summers and temperate winters are common in the southern areas, even at high elevations. At the northern end of the Appalachian Trail in Maine, the mean annual temperature during the period 1971 through 2000 was $3.9^{\circ} \mathrm{C}$, and the mean annual precipitation was 39.0 in. (U.S. Department of Commerce, 2003). The mean daily temperature in Maine over this period ranged from $-12.2^{\circ} \mathrm{C}$ in January to $18.3^{\circ} \mathrm{C}$ in July (PRISM Climate Group, 2006a). By comparison, the mean annual temperature at the southern end of the Appalachian Trail in north-central Georgia over the same period was approximately $15^{\circ} \mathrm{C}$, and the mean annual precipitation was 55.9 in. (U.S. Department of Commerce, 2003). In Georgia, the mean daily temperature over this period ranged from $5^{\circ} \mathrm{C}$ in January to $25^{\circ} \mathrm{C}$ in July (PRISM Climate Group, 2006a). The mean annual precipitation along the Appalachian Trail was approximately 52.0 in. during the period 1971 through 2000 (PRISM Climate Group, 2006b). 


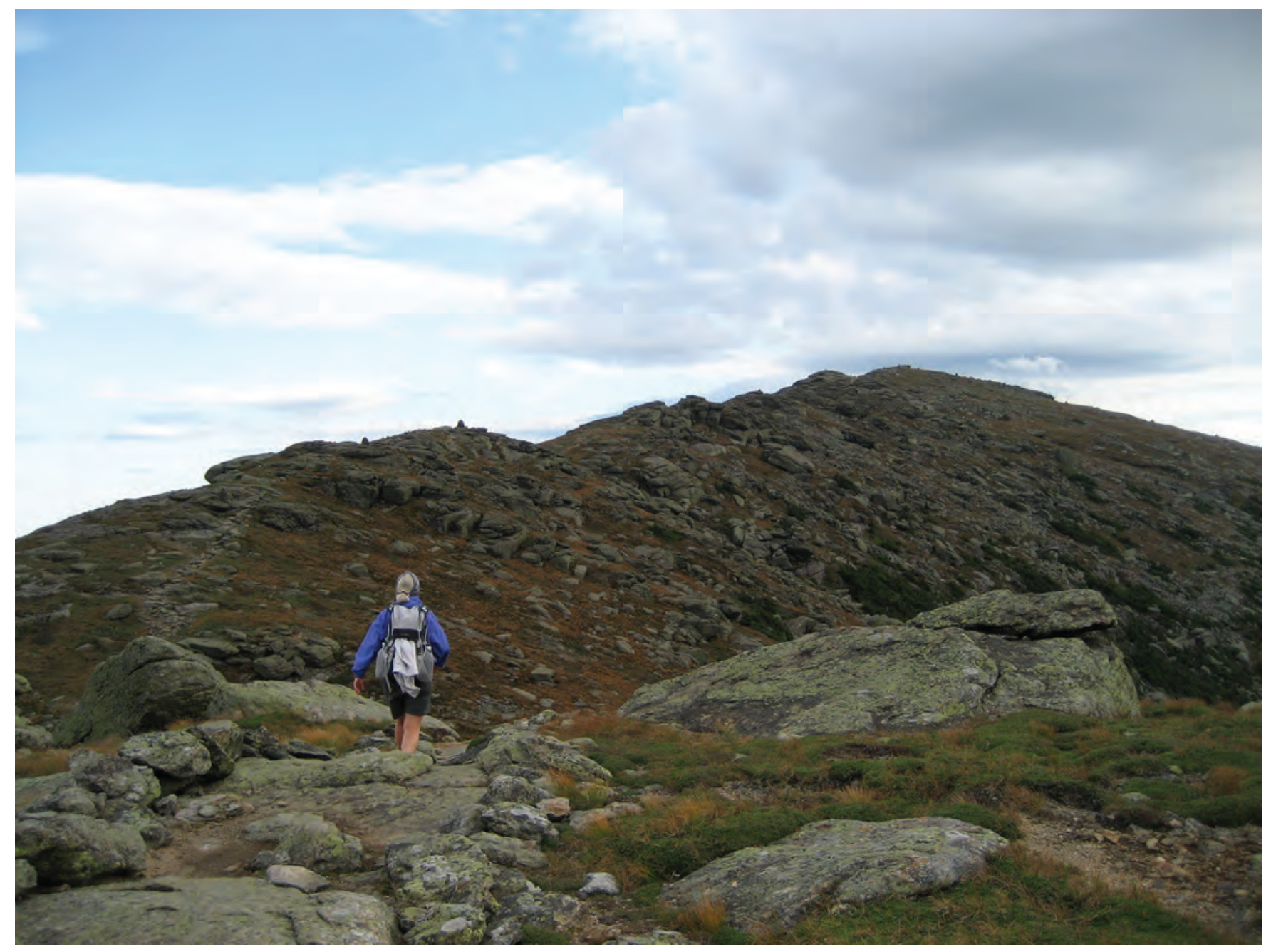

Figure 5. The Appalachian National Scenic Trail on Franconia Ridge, near Franconia, New Hampshire. (Photograph courtesy of Ann Chalmers, U.S. Geological Survey)

Snowfall was measured between 1971 and 2000 at 12 long-term weather stations in the study area (National Climate Data Center, 2005). The greatest annual snowfall during this period was observed at Mount Washington, New Hampshire, where there was a mean annual value of $26.3 \mathrm{ft}$ of measurable snowfall (National Climatic Data Center, 2005). Excluding the exceptional snowfall at Mount Washington, mean annual snowfall measured at stations in the study area ranged from $7.6 \mathrm{ft}$ in Millinocket, Maine, to $0.82 \mathrm{ft}$ in Knoxville, Tennessee (National Climatic Data Center, 2005). Variation in snowfall appears to be related primarily to latitude, although elevation and other climate factors also affect total annual snowfall.

In general, temperature and precipitation both increase from north to south along the Appalachian Trail. However, extreme climatic variations over small distances in the Appalachian Mountains result from local topographic and orographic effects. One example is Mount Washington in
New Hampshire, which has a mean annual precipitation of 102 in. at the summit (elevation 6,259 ft), while Berlin, N.H. (elevation $928 \mathrm{ft}$ ), a town only $18 \mathrm{mi}$ away, has an average annual precipitation of 40.0 in. (U.S. Department of Commerce, 2003).

\section{Hydrology}

The Appalachian Trail crosses about 1,700 streams and 100 rivers from Maine to Georgia (fig. 6). Most of these streams are 'low-order' intermittent, first-, and second-order streams (Matt Robinson, National Park Service, written commun., 2006). These low-order streams are of particular interest because they are considered to be representative of the forested, mountainous, and high-elevation terrain that characterizes most of the Appalachian Trail environment. Larger streams and rivers - such as the Connecticut, the Hudson, and 


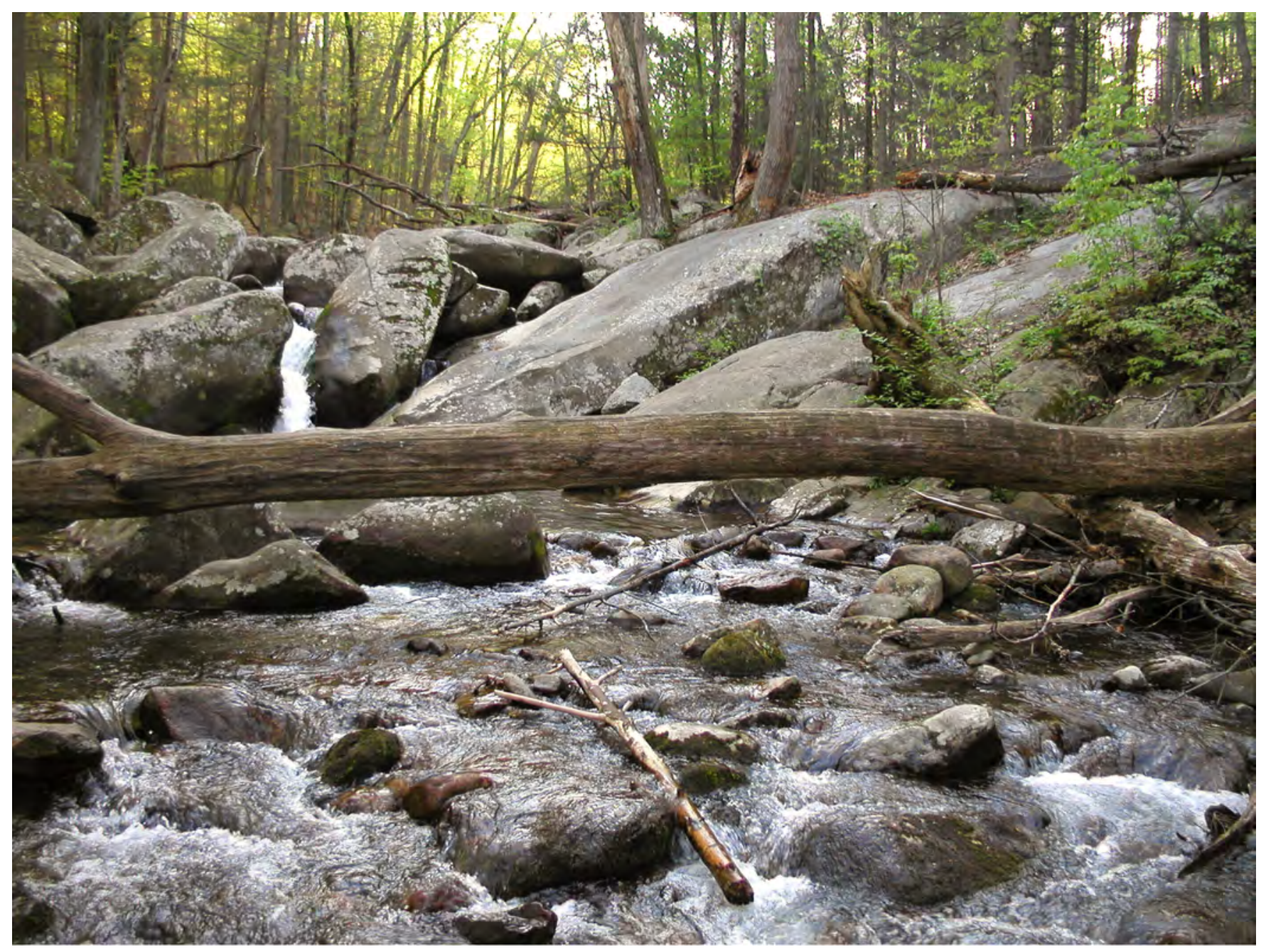

Figure 6. A first-order stream, typical of the high-elevation streams that are crossed by the Appalachian National Scenic Trail. Brokenback Run is a tributary to the Hughes River near Nethers, Virginia. (Photograph courtesy of Jason Pope, U.S. Geological Survey)

the Potomac - are typically at lower elevations, and because the water quality is reflective of larger drainage basins and multiple contributing land uses that originate outside of the Appalachian Trail environment, they are not necessarily characteristic of the Appalachian Trail water resources. Consequently, these large stream and rivers, while important are beyond the scope of this report.

\section{Physiographic and Ecological Divisions}

Physiographic provinces are large-scale divisions that represent the topographic expression of the land surface and the geology and geologic history of a region (Fenneman and Johnson, 1946). Each province exhibits specific characteristics resulting from distinct combinations of geology, hydrology, precipitation, and temperature. Consequently, these provinces provide general geographic areas that help to describe variations in the environment within the study area. The Appalachian Highlands Physiographic Division encompasses the entire study area, and within this division are six physiographic provinces (from north to south along the Appalachian Trail): New England, St. Lawrence Valley, Valley and Ridge, Appalachian Plateaus, Blue Ridge, and Piedmont. The St. Lawrence Valley Physiographic Province only intersects a very small area of the study area in west-central Vermont. This province does not represent any significant spatial region of the Appalachian Trail study area and was therefore not included in the following discussion. The five physiographic provinces that do represent the Appalachian Trail study area are listed in table 1.

A similar but more detailed classification scheme provided by the USFS uses the concept of ecological subregions to incorporate the distinctive biological and ecological aspects of the landscape with the physical features at several levels 


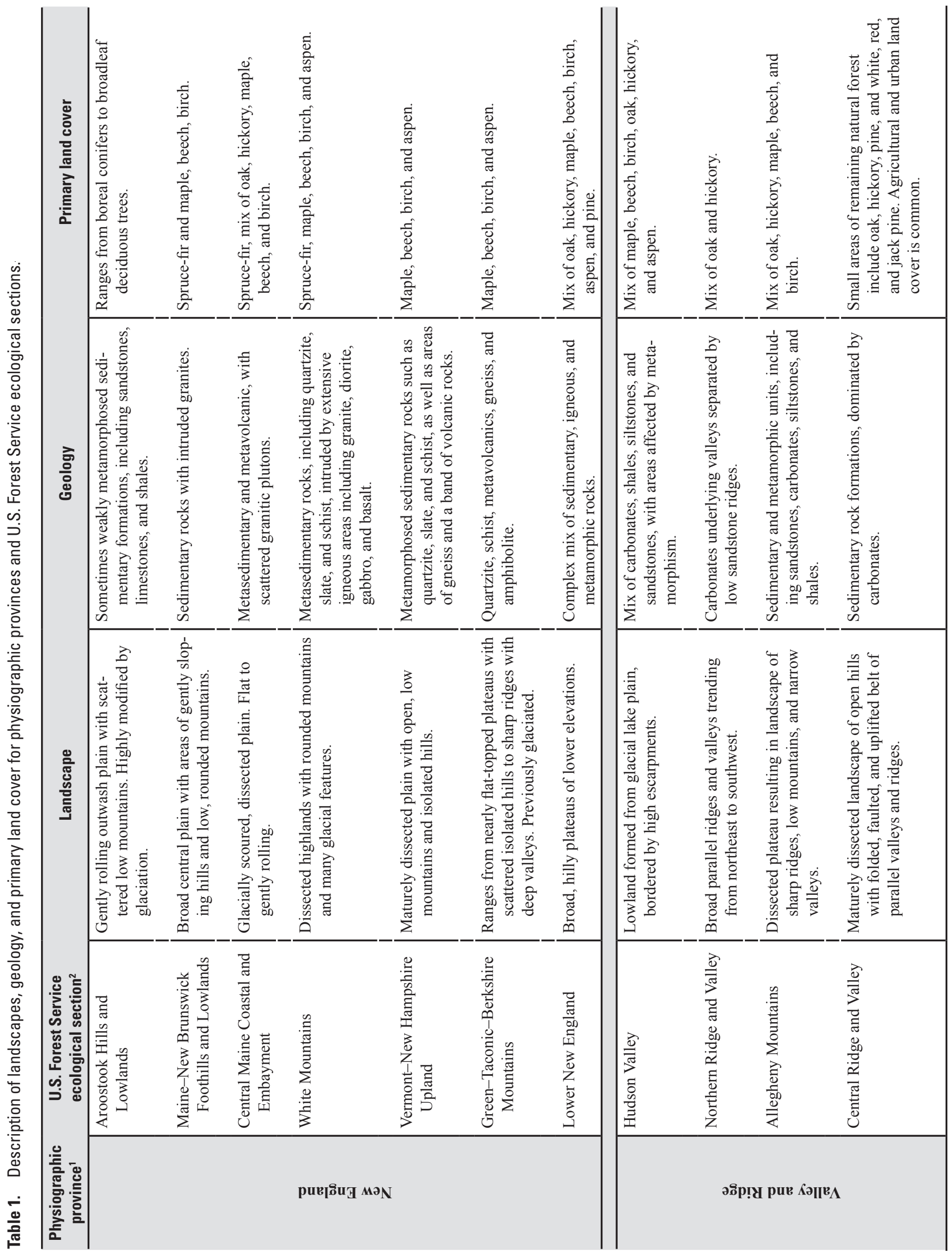




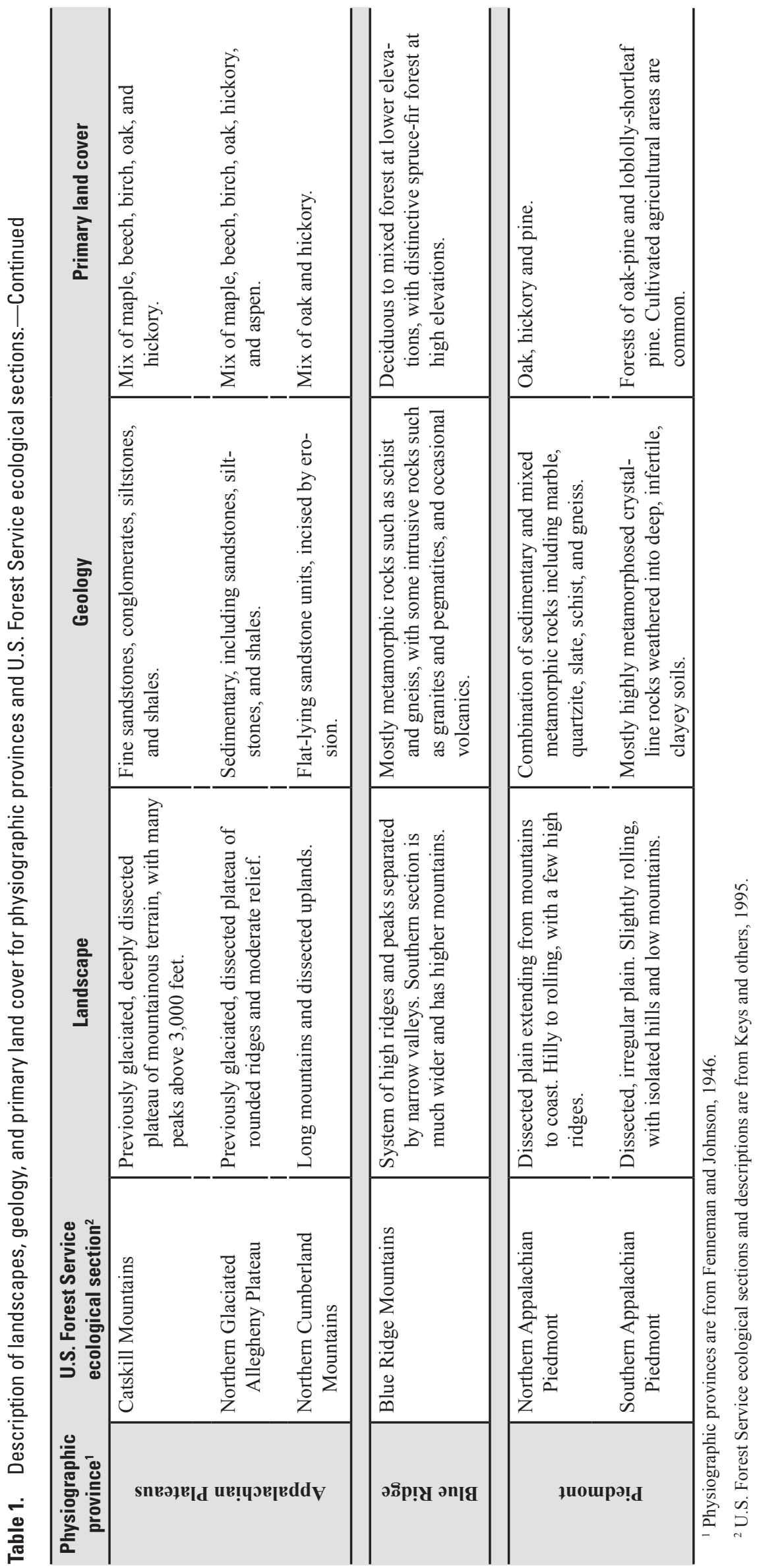


of geographic resolution (Keys and others, 1995). Of most interest to the current project were the ecological sections, which are described by Keys and others (1995) as "large land areas of relatively homogeneous physical and biological components that interact to form environments of similar productive capabilities, response to disturbances, and potential for resource management"; ecological sections defined by the USFS (Keys and others, 1995) are referred to in this report as ecosections. These ecosections are useful for describing the Appalachian Trail environment in more detail than that provided by the more general physiographic provinces. The study area intersects 17 ecosections mapped by Keys and others (1995). These ecosections are described in table 1, where they are presented in groups corresponding to physiographic province. The ecosections are shown in figure 7.

The New England Physiographic Province encompasses the Appalachian Trail study area from Maine to southern New York. Much of this province is characterized by a relatively cool climate because of both northern latitudes and high elevations. Winters are long with continual snow cover. This province includes several broad river valleys as well as peaks that are moderate in elevation (over 4,920 ft) with many peaks above treeline (Keys and others, 1995). The White Mountains of New Hampshire include the highest elevations on the Appalachian Trail north of Virginia, with Mt. Washington reaching over 6,200 ft (Keys and others, 1995). The underlying geology in the New England Physiographic Province is quite complex, resulting from multiple episodes of sedimentation, metamorphism, and intrusion, followed by extensive shaping of the landscape by glaciation. Ecosections within the New England Physiographic Province describe local ecological landscapes, with primary distinctions resulting from differences in geology, elevation, and the influence of coastal climatic conditions. Within the study area, the New England Physiographic Province includes seven ecosections: Aroostook Hills and Lowlands, Maine-New Brunswick Foothills and Lowlands, Central Maine Coastal and Embayment, White Mountains, Vermont-New Hampshire Upland, Green-Taconic-Berkshire Mountains, and Lower New England.

The Valley and Ridge Physiographic Province encompasses much of the western highlands of the Appalachian Mountains from New York to Georgia. Geologically, this province is characterized by folded and faulted sedimentary rocks. In general, the landscape is one of moderately high and narrow ridges approximately 1,500 to $3,500 \mathrm{ft}$ in elevation and separated by long, wide valleys, with both trending northeast to southwest, approximately parallel to the Appalachian Trail (Keys and others, 1995). The ridges are formed by relatively resistant sandstone, and the valleys are underlain by shale and carbonate rocks (Keys and others, 1995). The pattern of ridges and valleys results in a trellis-style drainage pattern for streams and rivers of this province. Within the study area, the Valley and Ridge Physiographic Province includes four ecosections: Hudson Valley, Northern Ridge and Valley, Allegheny Mountains, and Central Ridge and Valley.
The Appalachian Plateaus Physiographic Province is in southern New York and Pennsylvania and also along the southern part of the Virginia-West Virginia border. The Appalachian Trail never passes through the Appalachian Plateaus, but the province intersects the study area on the western edge. The Appalachian Plateaus are structural plateaus formed from relatively flat-lying sedimentary rocks that have been dissected by streams into an area of high relief. The northern section has been glaciated. Within the study area, the Appalachian Plateaus Physiographic Province encompasses three ecosections: Catskill Mountains, Northern Glaciated Allegheny Plateau, and Northern Cumberland Mountains.

The Blue Ridge Physiographic Province extends from central Pennsylvania to Georgia and is traversed by the Appalachian Trail over most of that distance, except for a large section in southwestern Virginia where the Appalachian Trail passes into the Valley and Ridge. On its eastern boundary, the Blue Ridge is distinguished by a steep escarpment separating it from the Piedmont province to the east, with relief of 1,000 to $1,600 \mathrm{ft}$ in many places along this boundary (Keys and others, 1995). The Blue Ridge province is a narrow band (less than $12 \mathrm{mi}$ wide) in its northern section and is characterized by a chain of relatively high mountain peaks ranging in elevation from approximately 3,000 to 4,000 ft and underlain primarily by metamorphic rocks, along with some plutonic and volcanic rocks, all highly resistant to weathering (Keys and others, 1995). The Blue Ridge province is much wider (approximately $75 \mathrm{mi}$ ) in the southern section, including areas in North Carolina, Tennessee, and Georgia, and is characterized by a system of high ridges forming several distinct mountain ranges separated by relatively narrow valleys. Most of this portion of the Blue Ridge province is underlain by metamorphic rocks such as gneiss and schist, with some intrusive rocks such as granites and pegmatites, and occasional volcanics (Keys and others, 1995). In this southern section, the Blue Ridge province includes numerous peaks and ridges with elevations exceeding 4,900 ft. The highest mountains of the Appalachian Trail are in this part of the province, including Clingmans Dome in Tennessee (Keys and others, 1995). This province includes some distinctive ecological environments, known as mountain balds (fig. 8). Within the study area, the Blue Ridge Physiographic Province includes only the Blue Ridge Mountains ecosection, which consists of deciduous to mixed forests at lower elevations and distinctive sprucefir forests at elevations above 4,900 ft (Keys and others, 1995). Many lower slopes of the Blue Ridge Mountains were cleared for agriculture in the $1800 \mathrm{~s}$, and most areas were selectively logged by the early 1900s (Keys and others, 1995), though some isolated areas of old-growth forest remain. The high elevations and steep slopes of this ecosection result in considerable orographic variations in temperature and precipitation.

The Piedmont Physiographic Province comprises the eastern foothills and lowlands adjacent to the high mountains of the Blue Ridge province immediately to the west. The Piedmont province is not crossed by the Appalachian Trail 


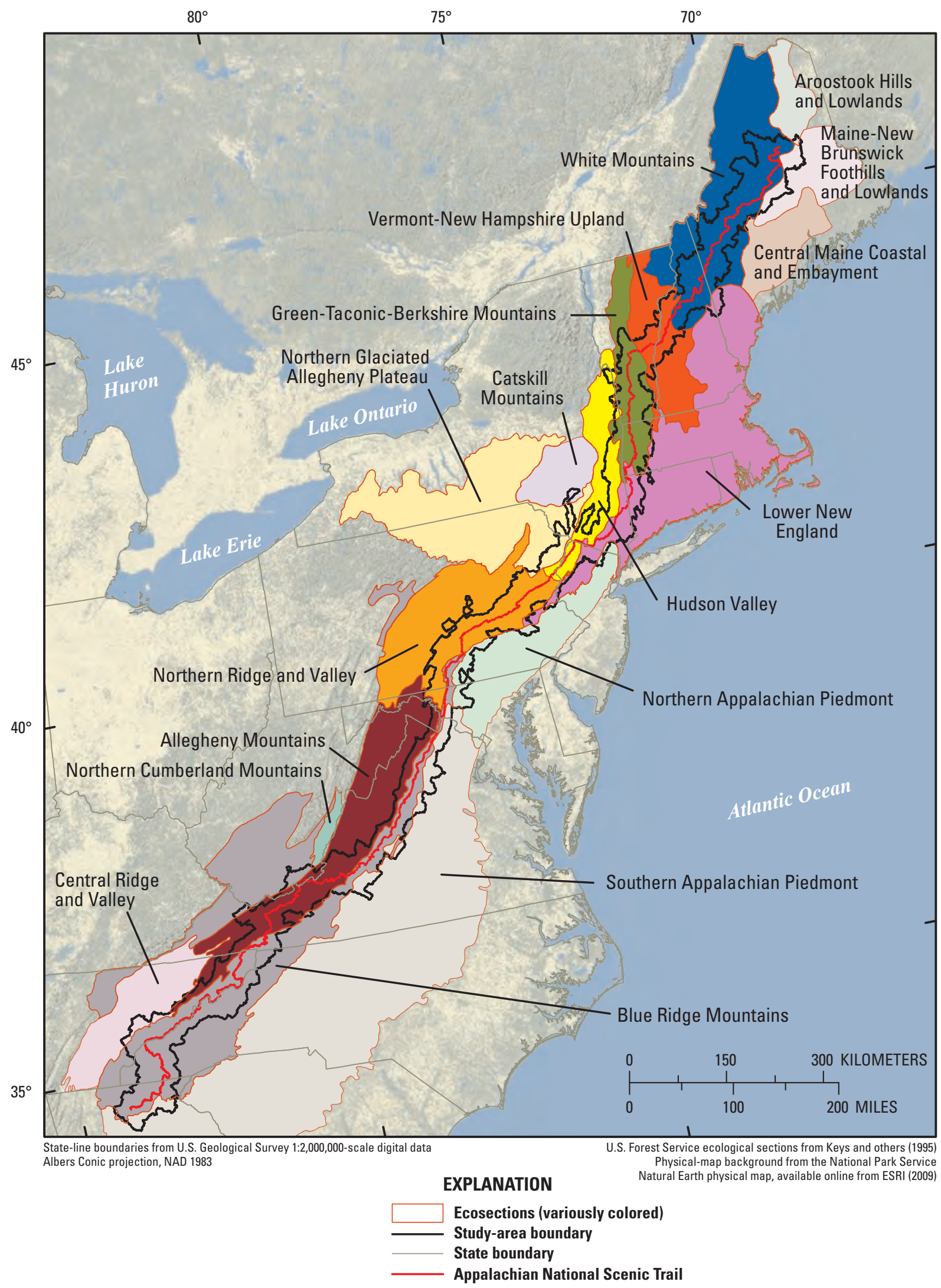

Figure 7. U.S. Forest Service ecological sections (ecosections) that intersect the study area. 


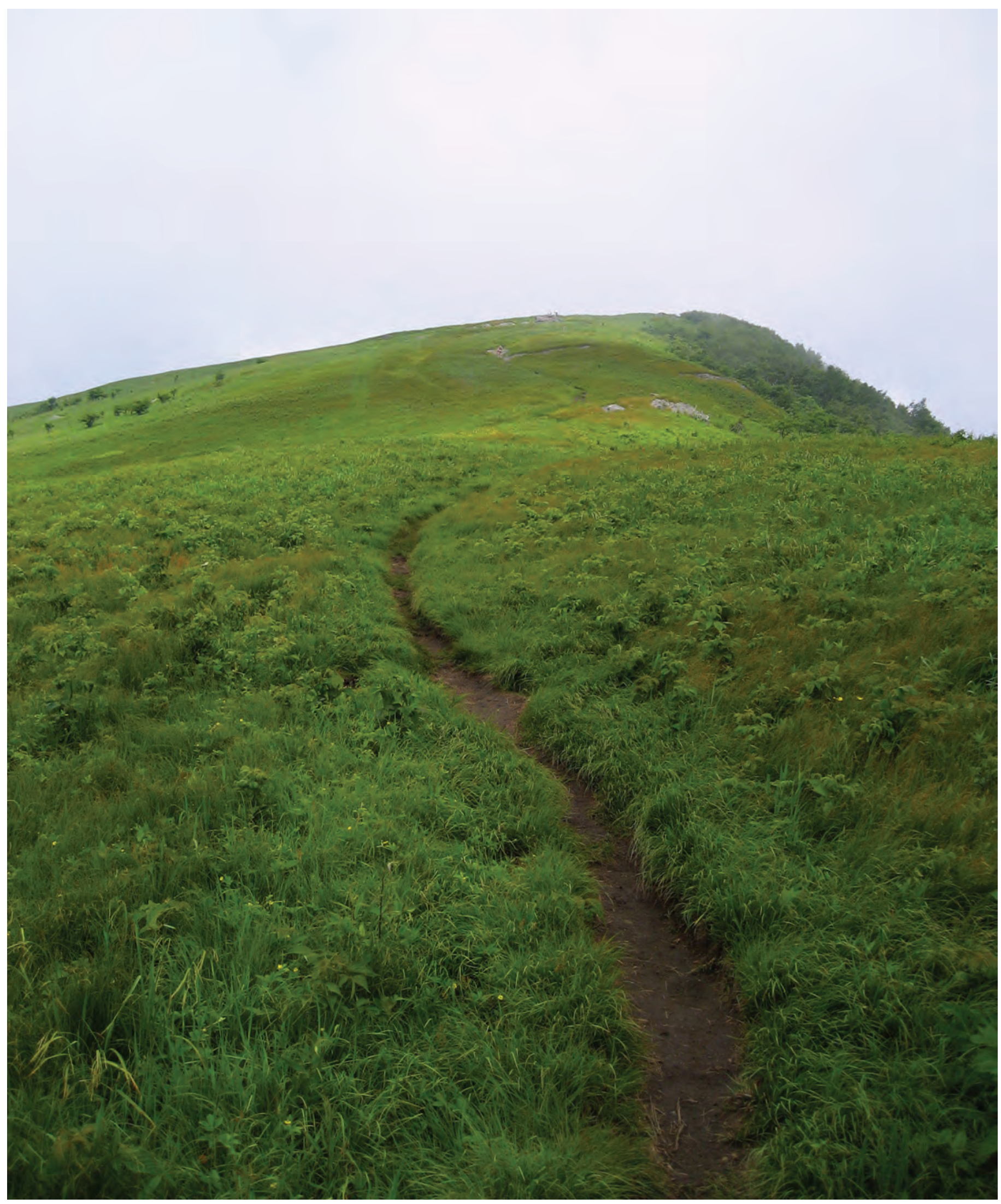

Figure 8. The Appalachian National Scenic Trail passing over Little Hump in North Carolina through the region known as the "balds." (Photograph courtesy of Ann Chalmers, U.S. Geological Survey) 
but is on the eastern edge of the study area from southern New York to Georgia. The terrain of the Piedmont province ranges in elevation from approximately 330 to $1,640 \mathrm{ft}$ and is underlain by metamorphic and igneous rocks that are the remnants of the tectonic events that formed the Appalachian Mountains (Keys and others, 1995). Hydrologically, this region is traversed by a number of wide river valleys that drain the eastern side of the Appalachians. Within the study area, the Piedmont province includes the Northern Appalachian Piedmont and Southern Appalachian Piedmont ecosections.

\section{Previous Investigations}

Although no assessment of the water quality along the entire Appalachian Trail has been completed, water quality has been the focus of numerous investigations within or near portions of the Appalachian Trail. While too many studies have been done to allow a review of each in this report, results from some of the more comprehensive and (or) ongoing investigations can be summarized. Many of these studies have focused on the affects of acid deposition as it relates to the acidification of surface-water bodies and the subsequent degradation of aquatic ecosystems. Generally, studies have found that the combination of regionally high inputs of acidic deposition, coupled with the generally low ionic strength of the surface waters and base-poor soils, makes the water resources of the Appalachian Mountains and nearby areas vulnerable to the detrimental effects of acidic deposition. Assessment of water quality conducted near regions of the Appalachian Trail have also correlated variations in land use, such as higher percentages of agricultural land or developed land, with variations in water quality.

The acidification of surface waters by acid deposition in many areas near the Appalachian Trail has been well documented. Driscoll and others (2001) reported that 41 percent of the lakes in the Adirondack Mountains and 15 percent of the lakes in New England have exhibited chronic or episodic acidification. Furthermore, they reported that 83 percent of affected lakes are acidic because of acidic deposition. Kahl and Scott (1988) documented the significant role of atmospheric deposition in the acid-base chemistry of high-elevation lakes in Maine. In addition, it was concluded that lakes in Maine at elevations higher than approximately 2,000 ft were more dilute, less buffered, and probably more vulnerable to acidic deposition than low-elevation lakes in Maine.

Acid-base chemistry in small streams in the Appalachian Mountains of Virginia (including Shenandoah National Park (Sullivan and others, 2004; Webb and others, 2004; Cosby and others, 2006; Rice and others, 2007) and the Blue Ridge Mountains of North Carolina and Tennessee including Great Smoky Mountains National Park and Coweeta Long-Term Ecological Research area (Cook and others, 1994; Robinson and others, 2008; John Schwartz, University of Tennessee, Department of Civil and Environmental Engineering, written commun., 2008; Cai and others, 2009) has been studied for years, and the effects of acidic deposition have been well documented. Approximately 93 percent of streams in the western mountains of Virginia were classified as sensitive to the effects of acidic deposition, 49 percent were classified as extremely sensitive, and 10 percent were classified as acidic (Charles and Christie, 1991). Of 54 low-order streams and 67 lakes sampled in the southern Blue Ridge Mountains, no surface-water bodies were classified as acidic, although the waters of this region also have low ionic strength and are sensitive to acidic inputs (Charles and Christie, 1991).

Surface waters that are classified as acidic or sensitive to acidic deposition are of interest because of the negative effects that acidic water can have on terrestrial and aquatic ecosystems. Seasonal and (or) event-driven increases in discharge that temporarily depress ANC in a water body are collectively referred to as episodic acidification. The occurrence and effects of episodic acidification have been well documented in surface waters in the Northeast (Driscoll, 1985; Wigington and others, 1996; Baker and others, 1996; Baldigo and Murdoch, 1997; Driscoll and others, 2001; Lawrence and others, 2004), in the Blue Ridge Mountains (Hyer and others, 1995; Rice and Bricker, 1995; Rice and others, 2005; Cosby and others, 2006), and in the Great Smoky Mountains National Park (Deyton and others, 2009; Neff and others, 2008). One way that repeated exposure to episodic acidification affects terrestrial ecosystems in the Appalachian Mountains is that the increased concentration of anions in acidic deposition leaches and depletes base cations from soils (Lawrence, 2002; Bailey and others, 2005; Cosby and others, 2006; Elias and others, 2009) and researchers have shown that depletion of base cations from soil has negatively affected forest health (Driscoll and others, 2001; Bailey and others, 2005; Elias and others, 2009). One effect of episodic acidification on aquatic life is the decrease in the ANC or $\mathrm{pH}$ can facilitate the release of aluminum from the soil, specifically monomeric aluminum, which can be toxic to fish (Driscoll, 1985; Baldigo and Murdoch, 1997). Studies conducted in the Northeastern United States to investigate the harmful effects of inorganic monomeric aluminum on brook trout (Salvelinus fontinalis) reported both temporary and long-term harmful effects on fish populations (Baker and others, 1996; Baldigo and Murdoch, 1997). Neff and others (2008) demonstrated the detrimental effects of episodic acidification on the health of brook trout (Salvelinus fontinalis) in the Great Smoky Mountains National Park.

Rice and others (2005) developed a model to predict the vulnerability of streams in Shenandoah National Park to episodic acidification. The model indicated that large areas of the park are vulnerable to sustained intervals of episodic acidification that could be harmful to fish populations, and that the geology, elevation, and size of the drainage area are effective predictors of susceptibility to episodic acidification. Sullivan and others (2007) used ANC to evaluate variations in the spatial distribution of acid-sensitive and acid-affected streams in relation to watershed features in the southern Appalachian Mountains. Findings from this study suggest that elevation, lithology, size of the drainage area, and forest type can be useful predictors of acid-sensitive and acid-affected watersheds. 
Since the passage of the Clean Air Act Amendments of 1990 (CAAA), the responses of surface-water-chemistry in acid-sensitive regions along the Appalachian Trail to reductions in sulfur dioxide and nitrogen oxides imposed by the CAAA have been studied. The USEPA's Acid Rain Program has reported substantial reductions of sulfur dioxide and nitrogen oxides in atmospheric deposition (U.S. Environmental Protection Agency, 2010a). Researchers' have examined the reactions of surface waters to these reductions in acidic deposition, and reported that concentrations of sulfate and, to a lesser extent, nitrate in surface water decreased after sulfate and nitrate in deposition had decreased (Driscoll and others, 1998; Driscoll and others, 2003; Stoddard and others, 2003; Kahl and others, 2004; Webb and others, 2004; Monteith and others, 2007; U.S. Environmental Protection Agency, 2010a). Many of these studies assessed the recovery of surface waters to changes in atmospheric deposition as reflected by increases in ANC and (or) $\mathrm{pH}$ coupled with decreases in concentrations of sulfate. Stoddard and others (2003) and Kahl and others (2004) reported that the response rates of surface waters varied and lagged behind decreases in deposition, but that surface waters with the lowest ANC and $\mathrm{pH}$ gave the largest and most rapid response.

These studies, which measured the responses of surface-water-chemistry to reductions in acidic deposition from the CAAA, also demonstrated that these measures of change (increases in ANC and (or) $\mathrm{pH}$ and decreases in concentrations of sulfate) could be attributed to or be impeded by other environmental alterations. Stoddard and others (2003) and Rosfjord and others (2007) both reported that in the glaciated regions of the Northeast, concentrations of calcium and magnesium in soil have continued to decline despite the reduced input of anions from acidic deposition. Rosfjord and others (2007) noted that increasing surface-water concentrations of chloride caused by road-salting practices have altered the acid-base chemistry in affected watersheds, and that this interaction is complicating the assessment of the response of surface waters to changes in acidic deposition. Stoddard and others (2003) noted that increases in the natural organic acidity of surface waters also is complicating the assessment of recovery since passage of the CAAA. Monteith and others (2007) determined that increases in concentrations of dissolved organic carbon were proportional to decreases in the deposition of sulfate and sea salt. Webb and others (2004) reported that in the mountains of western Virginia, sulfate deposition in precipitation decreased by approximately 40 percent from 1995 to 2000, although concentrations of sulfate in streamwater did not decline to a similar extent. Their findings corroborate and refine the conclusion from Kahl and others (2004) that the retention of sulfur in watershed soils in some regions of western Virginia affected the apparent disconnect between changes in sulfate deposition and concentrations of sulfate in streamwater. Furthermore, defoliation caused by the gypsy-moth infestation in the mid-1980s to mid-1990s may confound the interpretation of trends in ANC over time (Webb and other, 2004). The defoliation and subsequent recovery from the infestation produced a temporary increase and then a decrease in nitrate concentrations that likely caused a corresponding decrease and increase in the ANC. They concluded that it would be difficult to discern what respective proportions of the recent increases in ANC in this region could be attributed to the recovery from the gypsy-moth infestation and the reductions in sulfate deposition.

Hickman and Fischer (2007) and Siemion and Murdoch (2010) summarized streamwater quality in the Delaware Water Gap National Recreation area in Pennsylvania and New Jersey. Both studies reported positive correlations between water-quality constituents and the percentage of agricultural land cover in the drainage area. Specifically, Siemion and Murdoch (2010) showed that ANC and the concentrations of calcium, potassium, nitrate, total dissolved nitrogen, and dissolved phosphorus were correlated with the percentage of agricultural land cover. Hickman and Fischer (2007) also noted that wetlands in the Delaware River drainage area appeared to influence water quality in the Delaware Water Gap National Recreation area. Hickman and Fischer (2007) used linear regression to predict the differences in water quality between current (2002-2004) and future conditions.

Headwater stream chemistry is also important because of its subsequent effects on the water quality of downstream resources and aquatic communities. The effect of headwater streams on downstream water quality has been well documented (Alexander and others, 2007; Freeman and others, 2007; Nadeau and Rains, 2007). Alexander and others (2007) used a mass-balance watershed model based on stream networks in the northeastern United States to demonstrate the substantial contribution that first-order, headwater streams have on higher order streams with respect to mean annual flows and solute transport. Findings from this work showed that hydrologic and biogeochemical processes in headwater streams were physically and biochemically connected to the water quality downstream. Furthermore, the high proportional total length of headwater streams in the total stream length of a typical river drainage system (commonly over two-thirds) underscores the profound influence of the water quality of headwaters streams on the ecological integrity of streams and rivers at local and regional scales (Freeman and others, 2007).

\section{Sources of Water-Quality Data}

Many different projects with unique objectives have collected water-quality data from sampling sites along the Appalachian Trail. One of the primary objectives in compiling this level 1 water-quality inventory was to assess water-quality data from sites along or near the Appalachian Trail for use in determining water-quality conditions representative of the Appalachian Trail environment. Focus was given to data that had been collected at first- and second-order streams near the Appalachian Trail. Data were retained for consideration if the record included spatial information (latitude and longitude) 
and at least one water-quality constituent of interest, and if the data could be reasonably aggregated and compared with other datasets.

The data compiled for this project were collected by Federal, State, and university water-quality research programs. Data sources include the USGS; the U.S. Environmental Protection Agency (USEPA); the NPS; the USFS; the National Science Foundation (NSF), including the Long-Term Ecological Research (LTER) Program; the Water Resources Research Center at the University of Massachusetts, Amherst; and the Department of Environmental Sciences at the University of Virginia. Water-quality data from all of these sources were obtained in a variety of electronic formats.

Initially, data were obtained from the USGS's National Water Information System (NWIS) and USEPA's STOrage and RETrieval (STORET) databases (including Legacy STORET) (Dean Tucker, National Park Service, written commun., 2008). NWIS and STORET are national data warehouses for chemical, physical, and biological data from water, sediment, and tissue samples. More than 10 million records of water-quality data from about 16,800 sampling sites within $20 \mathrm{mi}$ of the Appalachian Trail were obtained for this project (table 2). The data obtained from NWIS and STORET constituted about 95 percent of all data initially compiled and included chemical, physical, and biological data. Data were from numerous projects with different objectives, methods of collection and analysis, and scales of focus. The remaining (approximately 5 percent) data were obtained from ten specific water-quality programs focused on areas near the Appalachian Trail. Many of these programs were designed to evaluate the effects of acidic deposition on surface-water resources.

\section{Acid Rain Monitoring Program}

The Acid Rain Monitoring (ARM) project is a program of the Water Resources Institute of the Massachusetts Water Resources Research Center at the University of Massachusetts, Amherst. The ARM project began in 1983 for the purpose of determining the sensitivity of Massachusetts lakes and streams to acidic deposition and evaluating trends in acidification (Acid Rain Monitoring, 2008). The data obtained from this program consist of more than 3,100 water-quality records from approximately 70 sampling sites (table 2). Samples typically were analyzed for $\mathrm{pH}$, major ions, $\mathrm{ANC}$, and some trace elements. Findings from this program are summarized in Godfrey (1998).

\section{Coweeta LTER Program}

The Coweeta experimental forest is part of the NSF's LTER Program, which supports long-term ecological research across a wide range of geographic scales. The LTER network includes 26 study areas primarily in the United States. Two of these study areas, Coweeta in North Carolina and Hubbard Brook in New Hampshire, are near the Appalachian Trail.
The Coweeta LTER study area focuses on the effects of disturbance and environmental gradients on biogeochemical cycling, and on the underlying watershed ecosystem processes that regulate and respond to the ecological cycles. The USFS also conducts research at the Coweeta LTER site independently and in collaboration with the NSF's LTER program. The USFS investigations primarily focus on the interaction between forest health and the water quality of streams. Coweeta furnished more than 13,000 water-quality records from 74 sampling sites (table 2). Samples typically were analyzed for $\mathrm{pH}$, specific conductance, ANC, major ions, nutrients, and organic carbon. However, specific studies at Coweeta address many different facets of ecosystem interaction (Coweeta Long Term Ecological Research, 2010).

\section{Hubbard Brook LTER Program}

The Hubbard Brook experimental forest is in the White Mountain National Forest, New Hampshire. It is part of the NSF's LTER program and is managed by the USFS Northern Research Station. Onsite research is broad based and includes studies relating to hydrology, biology, geology, and chemistry of the forest and its associated aquatic ecosystems (Likens, 1985; Likens and Bormann, 1995). The data obtained from this program consist of 16,900 water-quality records from 5 sampling sites (table 2). Samples typically were analyzed for $\mathrm{pH}$, major ions, and nutrients. However, specific studies at Hubbard Brook also address many different facets of ecosystem interaction (Hubbard Brook Long Term Ecological Research, 2010).

\section{Delaware Water Gap National Recreation Area}

Water-quality data were collected from 13 small streams in the Delaware Water Gap National Recreation Area (New York, New Jersey, and Pennsylvania) from July 2002 to September 2003 (table 2). These streamwater samples were analyzed for ANC, major ions, nutrients, carbon, and aluminum at the USGS New York Water Science Center laboratory (Jason Siemion, U.S. Geological Survey, written commun., 2009).

\section{Great Smoky Mountains National Park}

There are two components to the Great Smoky Mountains National Park water-quality program: Noland Divide water-quality monitoring and a park-wide waterquality survey. The Noland Divide is in the middle of Great Smoky Mountains National Park near the border of North Carolina and Tennessee. It is a small (17.4 ha), forested, high elevation $(5,500$ to $6,300 \mathrm{ft})$ watershed. This watershed was selected for long-term monitoring because its geographic location, high elevation, and underlying geology tend to make the watershed vulnerable to the effects of acidic deposition 
Table 2. Appalachian National Scenic Trail level 1 inventory of data sources used, project acronym, number of sampling sites, number of records, and the period of record for the water-quality data initially compiled.

[NPS, National Park Service; USEPA, U.S. Environmental Protection Agency; USFS, U.S. Forest Service; STORET, STOrage and RETrieval; USGS, U.S. Geological Survey]

\begin{tabular}{|c|c|c|c|c|}
\hline Data source & $\begin{array}{l}\text { Appalachian Trail project } \\
\text { data source acronym }\end{array}$ & $\begin{array}{c}\text { Number of } \\
\text { sampling sites }\end{array}$ & $\begin{array}{l}\text { Number of } \\
\text { records }\end{array}$ & Period of record \\
\hline $\begin{array}{l}\text { Acid Rain Monitoring Program; Water Resources Institute of } \\
\text { Massachusetts, Amherst }\end{array}$ & ARM & 73 & 3,148 & $1983-2008$ \\
\hline $\begin{array}{l}\text { National Science Foundation's Long-Term Ecological } \\
\text { Research Program, North Carolina }\end{array}$ & Coweeta LTER & 74 & 13,640 & 1998-2009 \\
\hline $\begin{array}{l}\text { National Science Foundation's Long-Term Ecological } \\
\text { Research Program, New Hampshire }\end{array}$ & Hubbard Brook LTER & 5 & 16,900 & $1963-2005$ \\
\hline Delaware Water Gap National Recreation Area ${ }^{1}$ & DEWA & 13 & 10,815 & $2002-2003$ \\
\hline $\begin{array}{l}\text { Virginia Trout Stream Sensitivity Study; University of } \\
\text { Virginia, NPS, USEPA, USFS, Virginia Department of } \\
\text { Game and Inland Fisheries, and Trout Unlimited }\end{array}$ & VTSSS & 353 & 5,148 & $2002-2003$ \\
\hline $\begin{array}{l}\text { White Mountain National Forest, New Hampshire } \\
\text { (Hornbeck and others, 2001) }\end{array}$ & WMNF & 210 & 78,781 & 1967-1999 \\
\hline Environmental Monitoring and Assessment Program; USEPA & EMAP & 225 & 20,273 & $1993-1998$ \\
\hline STORET Legacy Data Center; USEPA & Legacy STORET & 7,385 & $6,296,007$ & 1939-1998 \\
\hline STORET Data Warehouse; USEPA & STORET & 3,491 & $1,083,586$ & $1968-2007$ \\
\hline National Water Information System; USGS & NWIS & 3,698 & $2,643,058$ & 1923-2008 \\
\hline
\end{tabular}

\footnotetext{
${ }^{1}$ Water-quality data from the USGS New York Water Science Center (Jason Siemion, U.S. Geological Survey, written commun., 2009)
} 
(Cook and others, 1994; Robinson and others, 2008; John Schwartz, University of Tennessee, Department of Civil and Environmental Engineering, written commun., 2008; Cai and others, 2009). The Great Smokey Mountain park-wide water quality-monitoring project began in October 1993 and initially collected water samples from 367 sampling sites throughout the park that represented a range of elevations, geology types, and disturbance histories. Throughout the project, water-quality samples were collected at various intervals and subsets of sampling sites during base-flow conditions. The data obtained from these two programs consist of more than 55,000 water-quality records from 92 sampling sites (table 2). Samples typically were analyzed for $\mathrm{pH}$, specific conductance, ANC, major ions, nutrients, and some trace elements. Findings from both projects are summarized in annual NPS reports and various research publications including: Cook and others 1994; Neff and others, 2008; Robinson and others, 2008; Cai and others, 2009; Deyton and others, 2009.

\section{Virginia Trout Stream Sensitivity Study (VTSSS)}

The Virginia Trout Stream Sensitivity Study (VTSSS) collects data related to water chemistry in the Shenandoah National Park and the mountains of western Virginia for the general purpose of monitoring the quality of native brook trout streams. VTSSS data collected within Shenandoah National Park is coordinated with ongoing broad-based monitoring of water quality by the Shenandoah Watershed Study (University of Virginia, 2010). The data obtained from the VTSSS consist of more than 5,100 water-quality records from 353 sampling sites (table 2). Samples typically were analyzed for $\mathrm{pH}$, specific conductance, ANC, and major ions.

\section{White Mountain National Forest}

In 2001, the USFS compiled a database of water-quality data for the White Mountain National Forest, located in central New Hampshire (Hornbeck and others, 2001). The data obtained from this study consist of more than 78,700 waterquality records from 210 sampling sites (table 2). Samples typically were analyzed for $\mathrm{pH}$, specific conductance, ANC, major ions, nutrients, and trace elements.

\section{Environmental Monitoring and Assessment Program (EMAP)}

The USEPA initiated the Environmental Monitoring and Assessment Program (EMAP) in the late 1990s to monitor and assess the status and trends in ecological resources of the United States. The program evolved into a research program aimed at the development of tools for translating environmental-monitoring data from multiple spatial and temporal scales into assessments of current ecological conditions and forecasts of risks to natural resources. EMAP data used in this project were from small streams (first- through third-order streams) located within the study area. The data obtained from this program consist of more than 20, 200 water-quality records from 225 sampling sites (table 2). Samples typically were analyzed for $\mathrm{pH}$, specific conductance, ANC, major ions, nutrients, and organic carbon.

\section{Temporally Integrated Monitoring of Ecosystems and Long Term Monitoring Program (TIME/LTM)}

The USEPA's Temporally Integrated Monitoring of Ecosystems (TIME) project was developed as a special study within EMAP. The focus of the TIME program is to track the trends in the acid/base chemistry of acid-sensitive lakes in the northeast and streams in the central Appalachians (Stoddard and others, 1996). The primary objective of the Long Term Monitoring (LTM) program is to detect long-term trends in the acid/base status of lakes and streams across a gradient of acidic deposition nationally. The LTM network consists of a subset of lakes and streams that are particularly sensitive to acidity with most sampling-site records extending back to the early 1980s. The TIME and LTM are currently (2011) ongoing studies, and their data are commonly used together (U.S. Environmental Protection Agency, 2010b). The data obtained from these two programs consist of more than 280,000 waterquality records from 618 sampling sites (table 2). Samples were typically analyzed for $\mathrm{pH}$, specific conductance, $\mathrm{ANC}$, major ions, nutrients, organic carbon and inorganic carbon.

\section{National Stream Survey Program}

The USEPA's National Stream Survey program was designed to classify and characterize streams that are presently acidic or that have low ANC. In addition, the National Stream Survey program sought to identify streams appropriate for intensive long-term monitoring. The data obtained from this program consist of more than 46,500 water-quality records from 274 sampling sites (table 2) (U.S. Environmental Protection Agency, 2010c). Samples typically were analyzed for $\mathrm{pH}$, specific conductance, $\mathrm{ANC}$, major ions, nutrients, organic carbon, and inorganic carbon.

\section{Wadeable Stream Assessment Program}

The USEPA's Wadeable Stream Assessment program collected data for water-quality, biological, and physical-attribute assessments from wadeable streams and rivers across the United States (U.S. Environmental Protection Agency, 2006c). For this program, wadeable streams were defined as firstthrough fifth-order streams. The goal of the Wadeable Stream Assessment was to report on the condition of small streams in the United States and to establish a baseline with which to compare results from future studies. The data obtained from this program consist of more than 6,200 water-quality records from 293 sampling sites (table 2). 


\section{Methods of Analysis}

Water-quality data and ancillary spatial data were compiled from numerous sources to develop a comprehensive inventory appropriate for describing the water quality of headwater streams along the Appalachian Trail. An inventory and assessment of the water quality of headwater streams of the Appalachian Trail requires an explicit definition of what is meant by the phrase "water quality of the Appalachian Trail." A careful consideration of project objectives and an initial evaluation of data suggested that the specific area of interest should be larger than the immediate environment of the approximately 1000-ft-wide Appalachian Trail corridor to include relevant water-quality data. However, it also was apparent that inclusion of all water-quality data from first- and second-order streams within the study area would be too broad to be useful. Spatial data that delineates hydrologic boundaries and spatial data that characterizes environmental landscape attributes were used together to develop a method of site selection that resulted in an inventory of water-quality data representative of headwater streams along the Appalachian Trail. Environmental attributes also were used to describe possible anthropogenic and natural factors that may be influencing water quality. Water-quality data selected for inclusion in the resource characterization were aggregated to minimize the influence of intensively monitored sites and areas. The water quality of headwater streams along the Appalachian Trail was described through the use of computed summary statistics, comparisons of variations in summary statistics along the Appalachian Trail, and associations between water quality and environmental attributes.

\section{Quality Assurance and Compilation of Water- Quality Data}

Prior to analyzing the water-quality datasets described above, several quality-assurance measures were applied to identify potential errors in the reported water-quality values and to minimize issues that originated from combining data from multiple sources. Quality assurance steps taken to review the water-quality data included: removal of water-quality records determined to be inappropriate for use in analyses; assignment of an Appalachian Trail project site name to unify all records from the same sampling site; censorship of some nutrient values; and conversion of reported concentrations to standardized units.

\section{Quality Assurance}

Water-quality data were evaluated to determine if reported values were reasonable and appropriate for use in analyses. Three measures were used to determine if data were appropriate for use: comparison to USEPA criteria; comments or remark codes; and cation-anion balance. The USEPA has established typical ranges for many constituents and properties. These typical ranges, at one time, were used to screen data entered in STORET (National Park Service, 1998); all data were checked to ensure that they were within typical ranges. Water-quality values identified as suspect were then evaluated individually by comparing the values to other data from that site or similar nearby sites. Comments and remarks codes were evaluated to determine the quality of the reported value. Approximately, 16 percent of the samples selected had enough major ion data reported to calculate an ion balance. Ion balances were calculated on equivalent concentrations using procedures described by Hem (1992). Cation and anion concentrations were within 10 percent of each other for 93 percent of the sampling sites with sufficient data. The quality-assurance actions included:

- 255 records removed for exceeding the USEPA typical ranges,

- 43 records removed because the remarks code indicated that the value was compromised,

- 172 records of major ion data removed because the value was reported as zero, and

- 23 records removed because the cation/anion balance exceeded 10 percent.

These 493 water-quality records composed less than 0.003 percent of the data initially obtained.

\section{Data Compilation}

The uniqueness of each sampling site was evaluated relative to other nearby sampling sites through comparison of site-identification data, site names, and proximity. This step determined that approximately 10 percent of the sampling sites appeared in more than one of the datasets. A project-site name was created to unify all water-quality records from a sampling site. For the purposes of this quality-assurance step, sampling sites were considered identical if they had the same site name and were less than $330 \mathrm{ft}$ apart. Sampling sites that had the same identifier and were more than $330 \mathrm{ft}$ apart were retained as separate sampling sites. This method might have eliminated many duplications of sampling sites but also may have merged a small number of sampling sites that were actually unique. Considering the large number of sampling sites with data and the size of the study area, combining sampling sites in this manner probably affected the overall data-compilation effort to a minimal extent.

Data compiled for this study were from both unfiltered and filtered samples. Major ions, nitrate, and ammonia are generally in the dissolved form in these natural waters that are mainly in undisturbed landscapes. For this reason, data values from unfiltered (commonly referred to as total) and filtered (commonly referred to as dissolved) samples were combined for most constituents. More than 75 percent of major-ion samples used in this study were from filtered 
samples. Approximately 68 percent of ammonia samples were from unfiltered samples, and more than 87 percent of nitrate samples were from filtered samples. All total nitrogen and total phosphorus values used in analysis were from unfiltered water samples.

The issue of multiple detection limits for each constituent is inherent in a compiled dataset from a variety of sources that includes analyses from 1923 through 2009 (median year $=1995$ ). The minimum detectable concentration for a constituent is dependent on at least the following factors: the water matrix, sample-collection protocols, method of analysis, quality-control measures implemented by the analyzing laboratory, and objectives of the water-quality investigation. Concentrations below the minimum detectable concentration for a water-quality constituent are often censored and identified with a remark character indicating that the concentration is less than the minimum detectable concentration. Fewer than 0.3 percent of major-ion concentrations and approximately 28 percent of nutrient concentrations were reported as less than the respective minimum detectable concentrations. To the extent possible, reported values were retained and used as received. However, some nitrate and ammonia concentrations were reported as exceptionally low (less than $0.008 \mathrm{mg} / \mathrm{L}$ for nitrate and less than $0.01 \mathrm{mg} / \mathrm{L}$ for ammonia). These exceptionally low values were censored to improve the comparability of datasets by use of the following criteria:

- Concentrations of nitrate reported below $0.008 \mathrm{mg} / \mathrm{L}$ as $\mathrm{N}$ were set to less than $0.008 \mathrm{mg} / \mathrm{L}$, the USGS National Water Quality Laboratory's Long-Term Method Detection Level for nitrate (Childress, 1999). As a result, 3,835 concentrations of nitrate reported below $0.008 \mathrm{mg} / \mathrm{L}$ were censored to less than $0.008 \mathrm{mg} / \mathrm{L}$ as $\mathrm{N}$.

- Concentrations of ammonia reported below $0.01 \mathrm{mg} / \mathrm{L}$ as $\mathrm{N}$ were set to less than $0.01 \mathrm{mg} / \mathrm{L}$ as $\mathrm{N}$, the USGS National Water Quality Laboratory's Long-Term Method Detection Level for ammonia (Childress, 1999). As a result, 3,700 concentrations of ammonia reported below $0.01 \mathrm{mg} / \mathrm{L}$ as $\mathrm{N}$ were censored to less than $0.01 \mathrm{mg} / \mathrm{L}$ as $\mathrm{N}$.

The titration procedure used to measure ANC depends on whether the water is expected to be buffered primarily by carbonate solutes, most commonly carbonate and bicarbonate. In this case, the titration proceeds to theoretical $\mathrm{pH}$ endpoints for carbonate species ( $\mathrm{pH}$ values near 8.3 for carbonate and 4.5 for bicarbonate). The ANC of low-ionic-strength waters, like those in some regions along the Appalachian Trail, is generally presumed not to be controlled by the carbonate system; in this case, the Gran titration is used. The Gran titration measures the presence of species other than carbonate that contribute to ANC; the method requires detailed acidimetric data over the entire titration, is carried out to $\mathrm{pH}$ values of 3.5 or lower, and can result in a negative ANC value (Gran, 1952).

Reported values of ANC were determined by a variety of titration procedures. For the purposes of this inventory, if the sample was unfiltered and a titration was performed, it was considered to represent ANC. Approximately 50 percent of the values of ANC were determined by using Gran titration, of which 85 percent were from the section of the Appalachian Trail south of Maryland. To use as much available data as possible and to provide information regarding $\mathrm{ANC}$ in the northern section of the Appalachian Trail, all ANC data were combined regardless of the titration procedure. More frequent occurrence of low or negative ANC values in the southern section compared to the central and northern sections of the Appalachian Trail may be an artifact of the higher percentage of ANC determined through the use of the Gran titration method in the southern section of the Appalachian Trail.

Reported water-quality values were converted to ensure that units of concentrations were standardized and to ensure that the same species was analyzed for each constituent. Water analyses were initially reported primarily with four different units for concentration: micrograms per liter $(\mu \mathrm{g} / \mathrm{L})$, $\mathrm{mg} / \mathrm{L}, \mu \mathrm{eq} / \mathrm{L}$, and $\mu \mathrm{mol} / \mathrm{L}$. Water-quality constituents were converted as needed and are primarily summarized in $\mathrm{mg} / \mathrm{L}$. All ANC values are reported in $\mu \mathrm{eq} / \mathrm{L}$. Bicarbonate is reported as $\mathrm{mg} / \mathrm{L}$ as bicarbonate. Ammonia, nitrate, and total nitrogen are reported as $\mathrm{mg} / \mathrm{L}$ as nitrogen. Total phosphorus is reported as $\mathrm{mg} / \mathrm{L}$ as phosphorus. Nitrogen and phosphorus species conversions were based on procedures from Mueller and others (2005).

\section{Ancillary Data Sources}

Two primary types of ancillary spatial information were used: spatial data delineating hydrologic boundaries, and descriptive spatial data that characterized attributes of the environment, such as land cover. Descriptive spatial data were particularly useful in determining that the environmental setting of nonadjacent sampling sites were very similar to the Appalachian Trail environment. Therefore, it is likely that the water quality also would be representative of the Appalachian Trail environment. Ancillary spatial datasets also were used to help determine differences in the environmental settings of sampling sites where water quality varied along the Appalachian Trail. The spatial datasets used include information pertaining to physiography, land cover, and atmospheric deposition. A list of spatial data sources used for hydrologic and environmental attributes is shown in table 3.

\section{Hydrologic Attributes}

The extent of the study area and divisions within the study area were delineated by using the boundaries of hydrologic units (U.S. Department of Agriculture, 2005). Hydrologic-unit boundaries delineate successively smaller surface-water drainage areas of major rivers or the combined drainage areas of a series of rivers (Seaber and others, 1987). Hydrologic units used for this project include watersheds (also known as 10-digit hydrologic units) that were used to define 
Table 3. Types and sources of ancillary data used in this study.

\begin{tabular}{ll}
\hline \multicolumn{1}{c}{ Data type } & \multicolumn{1}{c}{ Source } \\
\hline NHDPlus & Hydrologic attribute data \\
Boundaries of hydrologic units & U.S. Environmental Protection Agency, 2006 \\
\hline & U.S. Department of Agriculture, 2005 \\
\hline Ecological subdivision & Environmental attribute data \\
Stream elevation & Keys and others, 1995 \\
Land-cover data & U.S. Environmental Protection Agency, 2006 \\
Slope & U.S. Environmental Protection Agency, 2006 \\
Elevation & U.S. Environmental Protection Agency, 2006 \\
Air temperature & Gesch, 2007 \\
Precipitation & PRISM Climate Group, 2006a \\
Soils data (STATSGO2) & PRISM Climate Group, 2006b \\
Geologic data & U.S. Department of Agriculture, Natural Resource Conservation Service, 2006 \\
Annual precipitation-weighted mean sulfate concentration & King and Beikman, 1974; Reed and Bush, 2005 \\
Annual precipitation-weighted mean nitrate concentration & National Atmospheric Deposition Program, 1994a \\
Nutrient ecoregions & National Atmospheric Deposition Program, 1994b \\
\hline
\end{tabular}

the extent of the study area, and subregions (also known as 4-digit hydrologic units) that were used to create subdivisions within the study area (fig. 9).

Delineation and characterization of the Appalachian Trail environment within the study area and characterization of the environmental setting of sampling sites was completed through the use of data from National Hydrography Dataset Plus (NHDPlus). NHDPlus is a suite of geospatial data products that have been developed to work in concert (U.S. Environmental Protection Agency, 2006a). The building blocks of NHDPlus were the medium-resolution National Hydrography Dataset (NHD), the National Elevation Dataset (30-meter), and the National Watershed Boundary Dataset. The fundamental feature of the NHDPlus dataset is the delineation of a catchment. A catchment is defined as the incremental drainage area for a single NHD hydrologic feature such as a stream segment (fig. 10). Stream segments and associated catchments are linked and nested so that the drainage area for a specific hydrologic feature includes its incremental drainage (catchment) area as well as the full cumulative drainage area upstream from that feature, including the headwaters (Johnston and others, 2009) (fig. 10). The NHDPlus geospatial database also contains derived physical attributes for each catchment, including slope, elevation of stream segments (hereafter referred to as stream elevation), and size of drainage area, as well as data integrated from other geospatial datasets, such as the National Land Cover Dataset (1992) (U.S. Geological Survey, 2000). Comparisons in differences in the size of drainage areas along the Appalachian Trail could not be assessed because of the varying resolution of the underlying hydrography data used in NHDPlus and the influence that this resolution disparity may have had in the delineation of catchment boundaries.

Catchments were used as the fundamental geographic units for this project because of the wealth of landscape data provided by NHDPlus for these small hydrologic units. Catchment boundaries were used to delineate and describe the Appalachian Trail environment, and water-quality data were aggregated and summarized by catchments. Two physical attributes of catchments (stream elevation and landcover information) were used to screen sites for inclusion in the water-quality summary and were tested as possible explanatory variables for observed variations in water-quality data. In addition, data for slope of the catchment, mean annual precipitation, and mean annual temperature were evaluated for correlations with environmental and water-quality variables. Strahler stream-order values available for every catchment through an NHDPlus extension were important in the siteselection process for defining first- and second-order streams. (Datasets that have been developed to provide additional information integrated with NHDPlus are referred to as data extensions.) 


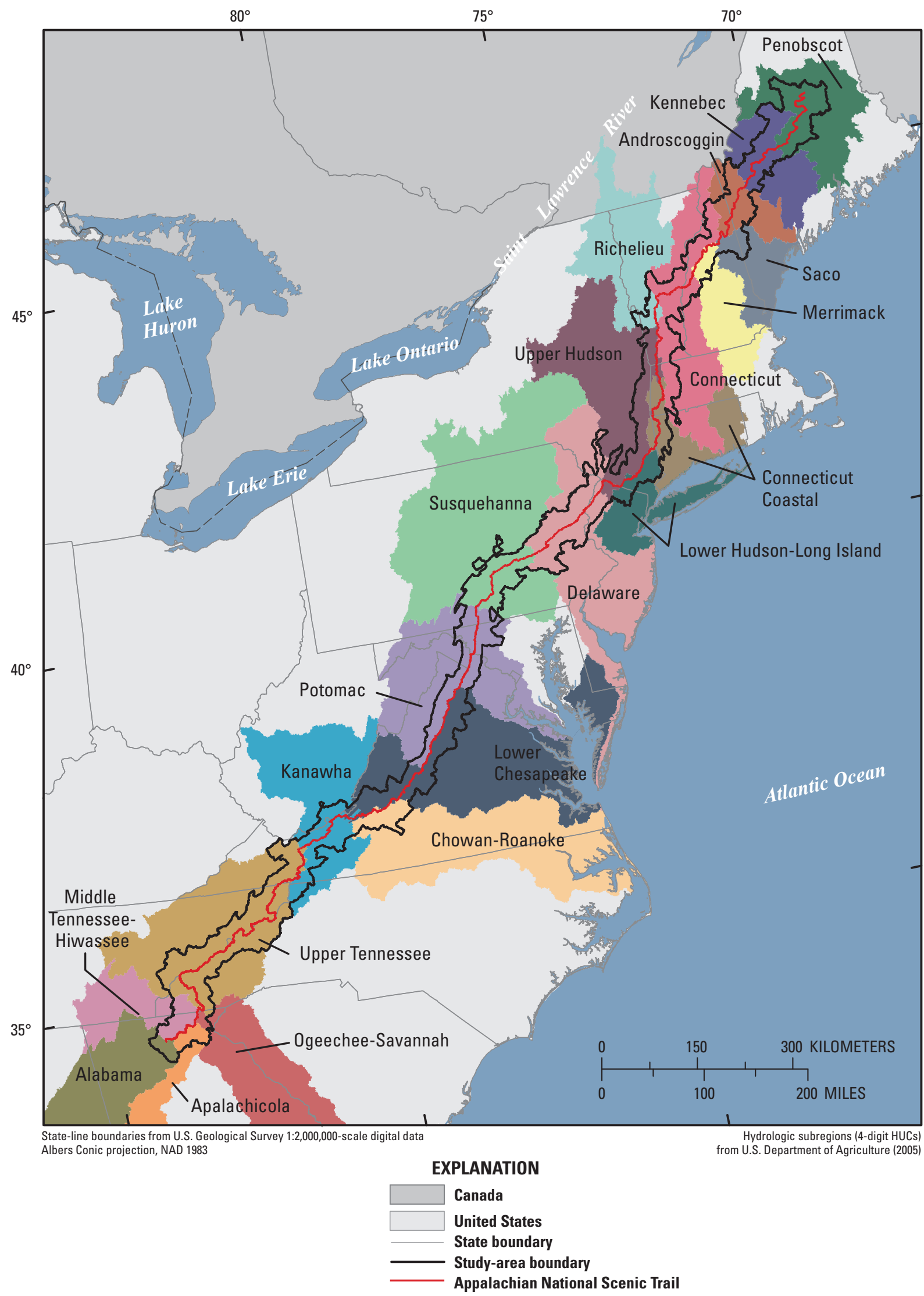

Figure 9. Hydrologic subregions (variously colored) that intersected and were used as geographic subdivisions of the study area. 


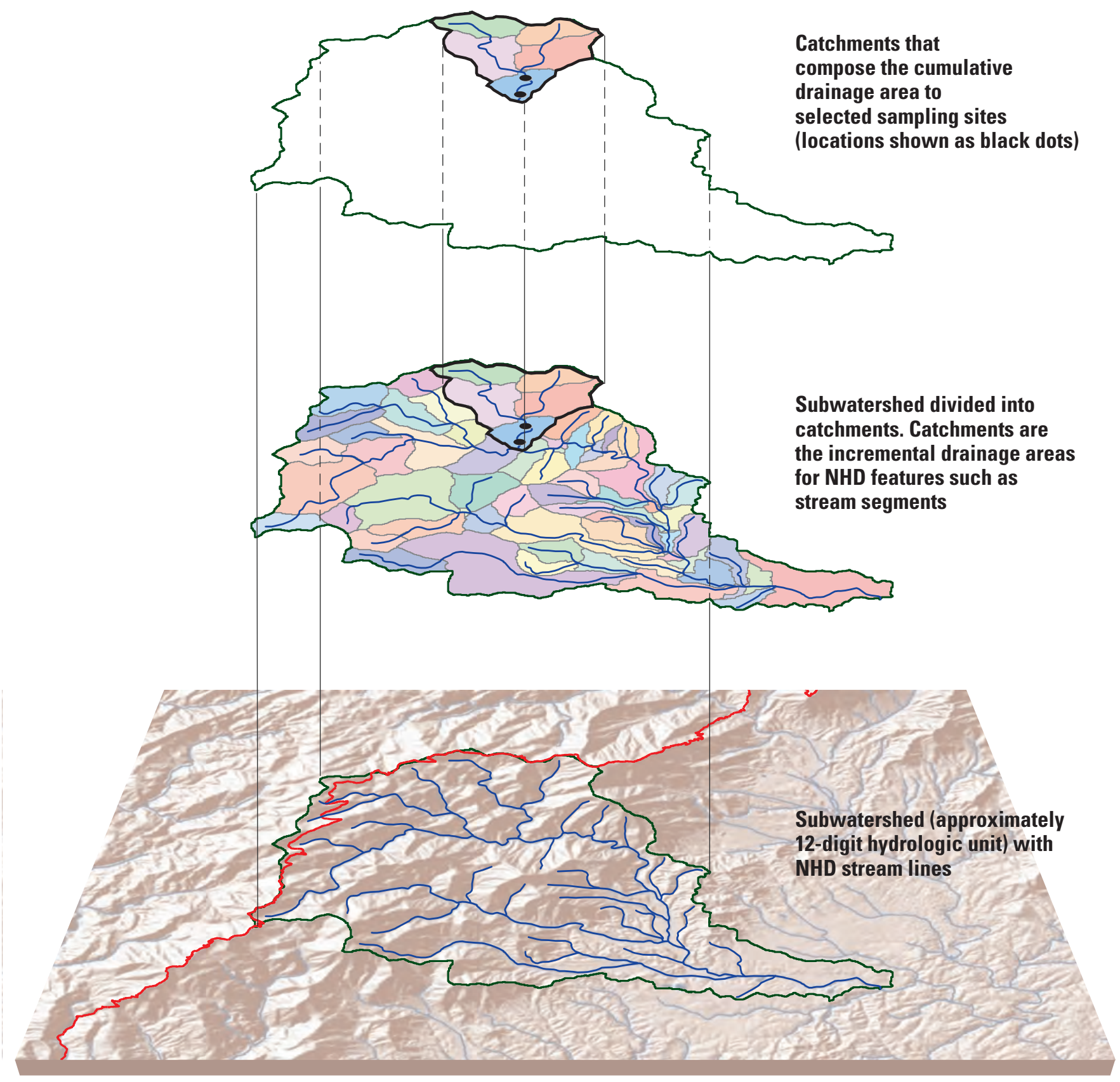

EXPLANATION

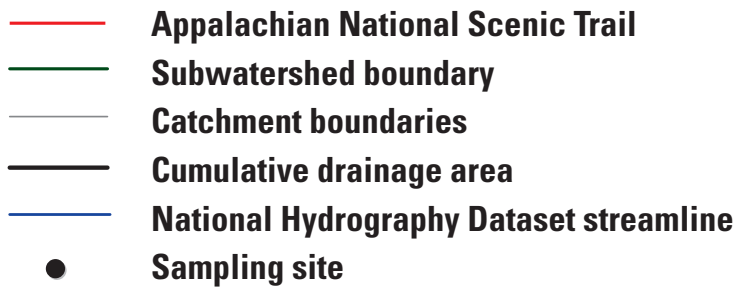

Figure 10. Schematic diagram showing examples of the nested relation of National Hydrography Dataset Plus (NHD Plus) catchments with larger delineated hydrographic units such as subwatersheds, and drainage areas defined for a set of nested catchments. 


\section{Environmental Attributes}

Ecosections defined by the USFS were used to group water-quality data and to relate spatial attributes to variations in water-quality data. Geologic data from Reed and Bush (2005) and King and Beikman (1974) were used to group catchments by major lithology type and evaluate variations in water quality. Concentrations of total nitrogen and total phosphorus were compared to USEPA nutrient criteria by nutrient ecoregions (U.S. Environmental Protection Agency, $2000 ; 2002 b)$. Concentrations of ammonia, nitrate, total nitrogen, and total phosphorus were compared to estimated background concentrations developed by the USGS (Dubrovsky and others, 2010).

Environmental attributes from most of the following spatial datasets were assigned based on the attribute values at the geographic center of each catchment. Topographic elevation data used to evaluate water-quality variations associated with elevation were assigned from digital elevation maps (Gesch, 2007). Land-cover data were obtained from NHDPlus, which contains information integrated from the National Land Cover Dataset from 1992. Mean annual precipitation and temperature data were obtained from the PRISM Climate Group (PRISM Climate Group, 2006a; b). Soils data were obtained from the Natural Resources Conservation Service's State Soil Geographic database (U.S. Department of Agriculture, 2006). Soils data used in the analysis included average range in permeability, average range in bulk density, average range in organic matter content, average percentage of clay content, average percentage of silt content, and average percentage of sand content. Precipitation-weighted annual concentrations of sulfate and nitrate in precipitation were obtained from the National Atmospheric Deposition Program (NADP) as continuous rasters interpolated from measurements at NADP sites (National Atmospheric Deposition Program, 1994a, b). Continuous rasters of yearly estimated sulfate and nitrate deposition (in mass per unit area) were computed from NADP concentration rasters and PRISM estimated annual mean precipitation rasters (PRISM Climate Group, 2006b) by using a method developed by Latysh and Wetherbee (in press).

\section{Site Selection}

The evaluation and selection of available sampling sites for this study were based on the stream-order, the proximities of the sites to the Appalachian Trail, and the environmental settings of the sampling sites. Sampling sites were assigned to an NHDPlus catchment through GIS analysis, and the environmental setting of each sampling site was characterized by the physical attributes compiled from available spatial data for the catchment. All selected sampling sites were on first- and second-order streams as determined by available data from NHDPlus.

All catchments that contained first- and second-order streams and directly adjacent to the Appalachian Trail were identified. Catchments defined as adjacent to the Appalachian
Trail included those for which the catchment polygon geographically intersected the Appalachian Trail corridor in a GIS analysis. These catchments, hereafter called adjacent catchments, encompass the headwaters that drain the Appalachian Mountains along the Appalachian Trail and were considered to represent the hydrologic environment of the Appalachian Trail. There are 2,565 first- and second-order adjacent catchments in the Appalachian Trail study area. NHDPlus data were used to evaluate and describe physical landscape characteristics associated with the adjacent catchments and thereby characterize the hydrologic environment of the Appalachian Trail headwater streams (figs. 11 and 12A-D).

The collective environment for all adjacent catchments was over 88 percent forested land, approximately 8 percent agricultural land, 2 percent open water or wetlands, and 1 percent developed land. However the Appalachian Trail environment differed widely along the trail. Adjacent catchments in the state of Maine were approximately 90 percent forested land, 7 percent water, and 3 percent bare rock. In contrast, the adjacent catchments in Pennsylvania and Maryland were approximately 65 percent forested land, more than 30 percent agriculture land, and more than 2 percent developed land. Approximately 25 percent of the length of the Appalachian Trail is in Virginia. The adjacent catchments in Virginia were 89 percent forested land, 10 percent agricultural land, and less than 1 percent developed land. The adjacent catchments in the state of Georgia were more than 99 percent forested land. For this investigation, data collected from all sampling sites within adjacent catchments were retained for analysis because these sampling sites were considered to be representative of the hydrologic environment of the Appalachian Trail. A total of 309 adjacent catchments contained at least one sampling site selected for water-quality analysis in this study.

\section{Criteria for Selection of Nonadjacent Sampling Sites}

Sampling sites within the study area but not adjacent to the Appalachian Trail were evaluated for inclusion in this inventory to increase the amount of water-quality data used to describe the water resources of the Appalachian Trail. Physical attributes of adjacent catchments were compared with all other first- and second-order catchments in the study area. Through this analysis, it was determined that stream elevation, the percentage of the drainage area classified as developed land, and the percentage of the drainage area classified as agricultural land were the most important criteria to determine if nonadjacent sampling sites were similar to the Appalachian Trail environment.

The maximum stream elevation was used as the elevation variable for site selection rather than the maximum topographic elevation of the catchment because it more closely relates to the elevation at which a headwater streams forms. Developed land was defined to include low- and highintensity residential, as well as commercial, industrial, and 
transportation land cover. Land cover characterized as agricultural included pasture and row crops.

Stream-elevation and land-cover data from the adjacent catchments were aggregated by hydrologic subregion. The number of adjacent catchments varies by subregion and is related to topography and to the proportion of the Appalachian Trail within the subregion. Summary statistics of elevation and land-cover information from adjacent catchments within each subregion were used to develop criteria for the selection of nonadjacent sampling sites by subregion. Hydrologic subregions were selected for the aggregation of adjacent catchment attributes because they provided reasonable and informative geographic divisions of major landscapes within the study area. The 21 subregions that intersect the Appalachian Trail are shown in figure 9.

Nonadjacent sampling sites within the study area were selected for inclusion in the water-quality analysis if the following subregion criteria were met: (1) the stream elevation was equal to or greater than the lowest stream elevation of an adjacent catchment within the same subregion; (2) the percentage of agricultural land in the drainage area of the catchment did not exceed the 75th percentile for adjacent catchments within the same subregion; and (3) the percentage of developed land in the drainage area of the catchment did not exceed the 75 th percentile for adjacent catchments within the same subregion (table 4).

The thresholds for each of the criteria differ among the subregions and reflect the geographic variations in topography and land cover along the Appalachian Trail. The highest stream elevations were in the northern and southern subregions of the Appalachian Trail (table 4), while the lowest stream elevations were in subregions that coincide with the Hudson River Basin: the Upper Hudson, and the Lower Hudson-Long Island subregions (table 4). The thresholds for the percentage of developed land in the drainage area for all subregions were all less than 3 percent (table 4 ). In other words, nonadjacent sampling sites were never selected with developed land cover of 3 percent or greater in the drainage area. The threshold for the percentage of developed land in the drainage area was 0 for the 6 most southern subregions. Therefore, nonadjacent catchments could be selected in these subregions only if they contained no developed land cover. The subregions with the highest thresholds for the percentage of agricultural land cover were the Delaware (17.2 percent), the Susquehanna (26.8 percent), and the Potomac (27.7 percent) (table 4). Consequently in these subregions, nonadjacent sampling sites which had modest amounts of agricultural land cover in the drainage area were included in this inventory. The minimum stream-elevation thresholds in these subregions were useful in limiting the number of sampling sites retained with modest amounts of agricultural land cover.

\section{Selected Sites and Data Aggregation}

The final dataset for use in this project consisted of 1,817 stream-sampling sites in 831 different catchments that represent approximately 450 different first- and second-order streams. Some catchments contained multiple sampling sites and some streams were represented by multiple catchments. There were 946 adjacent sampling sites and 871 nonadjacent sampling sites in the final dataset. Specific areas that contain numerous selected sites include the White Mountain National Forest in New Hampshire (fig. 13A), the Delaware Water Gap National Recreation Area in Pennsylvania and New Jersey (fig. 13B), the Shenandoah National Park in Virginia (fig. 13C), and the Great Smoky Mountains National Park in Tennessee and North Carolina (fig. 13D). Some areas had relatively few selected sampling sites with available water-quality data, with the most notable data gaps in Maine (fig. 12A). Only seven sampling sites in the State of Maine met the project criteria and were retained for analysis. Central Vermont, western Massachusetts, and Georgia also had few sampling sites retained for water-quality analysis (figs. 13A-B, D).

In addition to spatial disparities in the number of sites, the number of times each site was sampled and the constituents analyzed for each sample also were highly variable. The number of times a selected site was sampled ranged from one to more than a thousand. The most frequently sampled sites were primarily in the Shenandoah National Park. Approximately 58 percent of the sites used in this study were sampled at least five times. Thirty-eight percent of the sampling sites used in this study were sampled only once.

To mitigate a potential bias resulting from disparities in the spatial locations of sampling sites and in the frequencies of sampling, the data were aggregated in four steps: (1) data were aggregated by sampling site and date to determine a daily median value for each constituent; (2) daily median values were aggregated by sampling site and year to determine an annual median value for each constituent (for example, if 300 daily median values of $\mathrm{pH}$ were recorded at a sampling site in one year, the median of these $300 \mathrm{pH}$ values was determined as the annual median value for that year); (3) annual median data were aggregated by site, thus reducing the data to one median annual value for each constituent at that site for the entire sampling period in years; and (4) data were aggregated by National Hydrography Dataset Plus (NHDPlus) catchments to a single median value for each constituent in each catchment. Sampling sites in the same catchment are on the same stream segment (fig. 10). The number of sampling sites within a catchment ranged from 1 to 55 ; however, 542 of the 831 catchments contained only one sampling site. The resulting values (hereafter referred to as catchment values or concentrations) for each constituent were used to assess water quality along the Appalachian Trail and are available in addition to ancillary data in the catchment-data worksheet of appendix 1. 


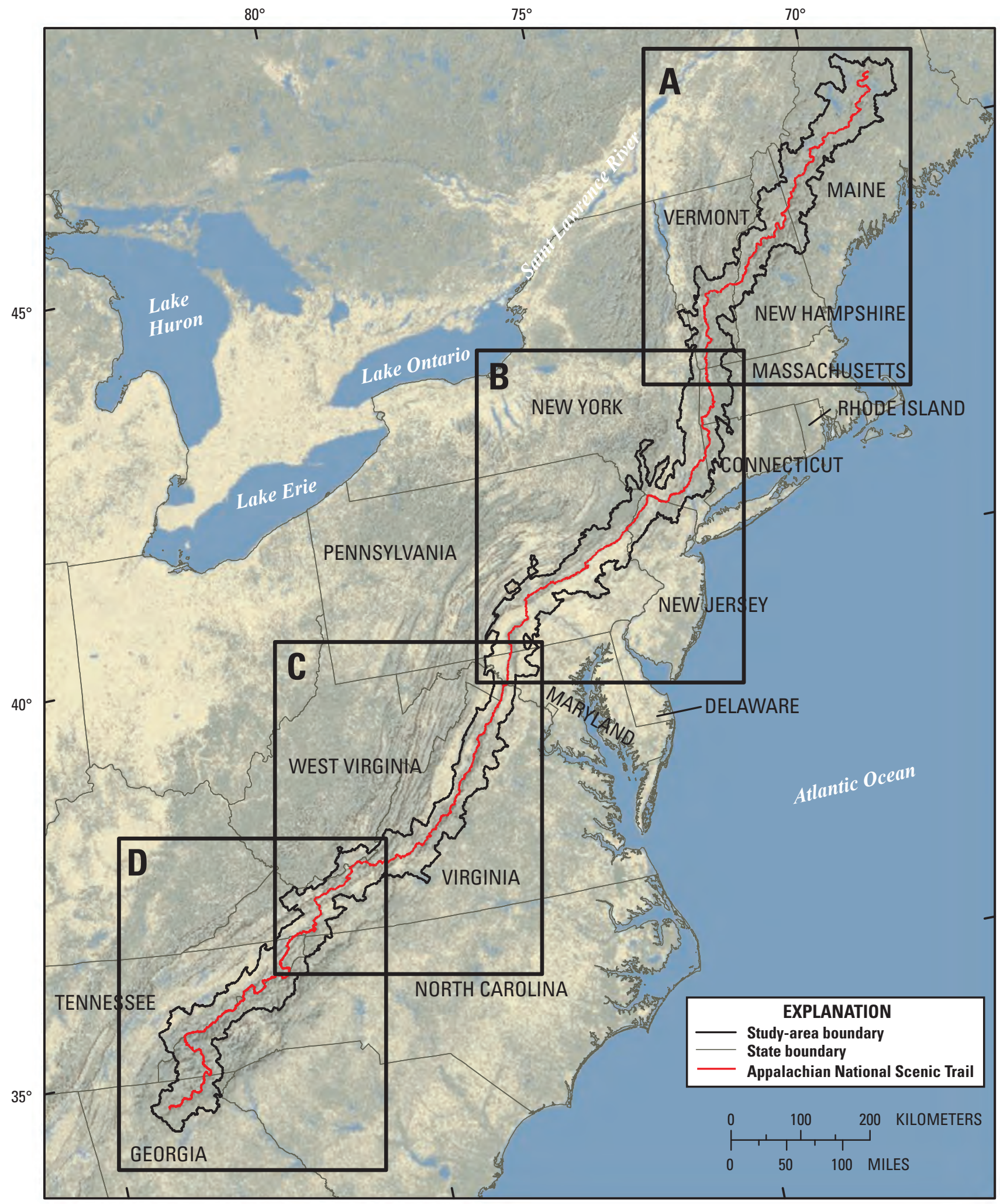

State-line boundaries from U.S. Geological Survey 1:2,000,000-scale digital data

Base physical-map background is from U.S. National Park Servic Albers Equal-Area Conic projection, NAD 1983 Natural Earth physical map, available online from ESRI (2009)

Figure 11. Index map showing areas covered by figures 12 and 13 . 


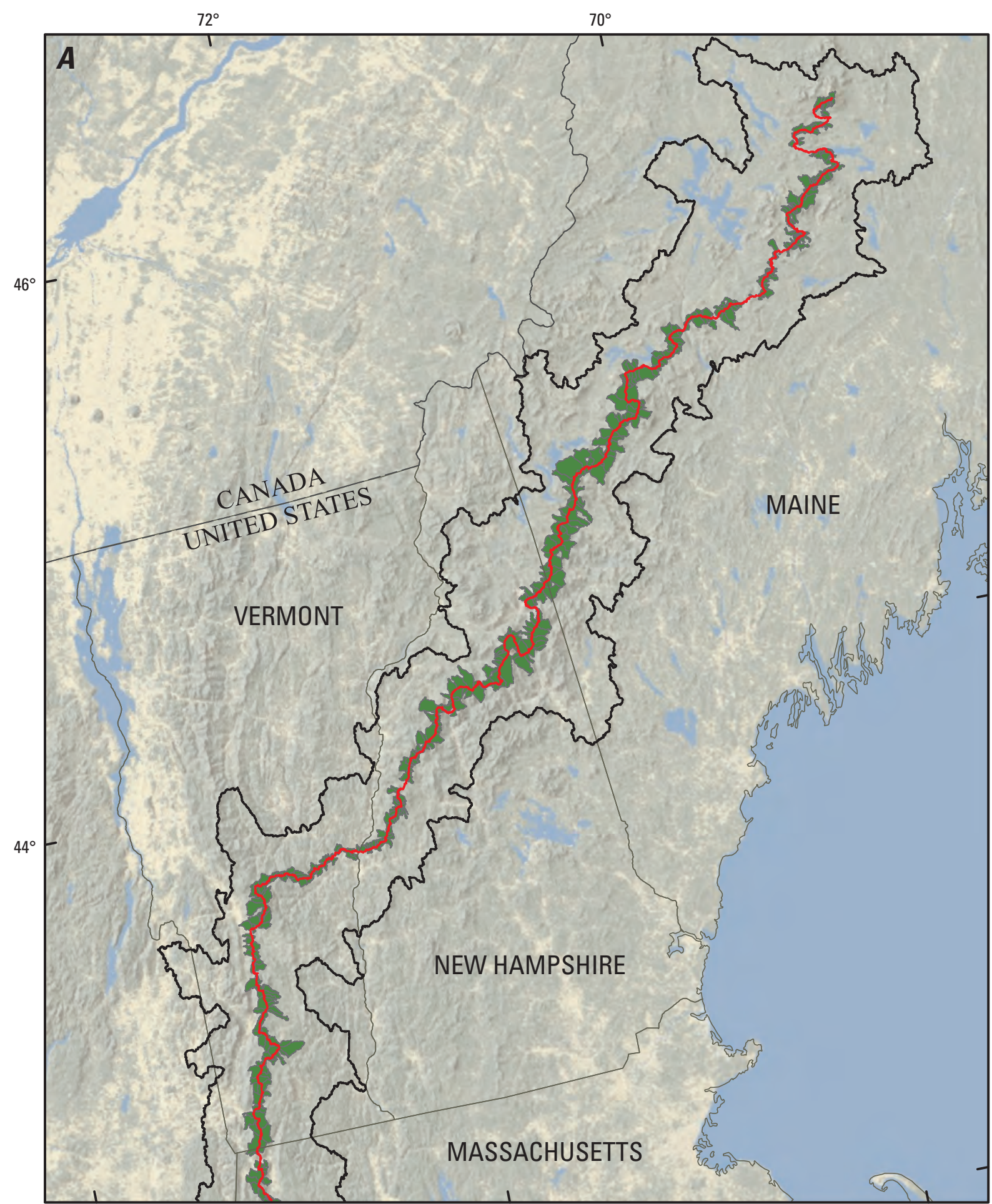

State-line boundaries from U.S. Geological Survey 1:2,000,000-scale digital data Albers Conic projection, NAD 1983

Catchment boundaries from National Hydrography Dataset Plus (U.S. Environmental Protection Agency, 2006a) Physical-map background from the National Park Service EXPLANATION Natural Earth physical map, available online from ESRI (2009)

\section{Adjacent catchments \\ Study-area boundary State boundary Appalachian National Scenic Trail}

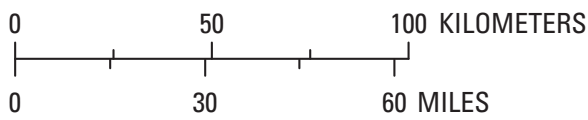

Figure 12. First- and second-order catchments from the National Hydrography Dataset Plus (NHD Plus) that are adjacent to the Appalachian National Scenic Trail and were used to characterize physical attributes of the trail environment from $A$, Maine to Vermont, $B$, Massachusetts to Maryland, $C$, Maryland to Virginia, and $D$, Virginia to Georgia. 


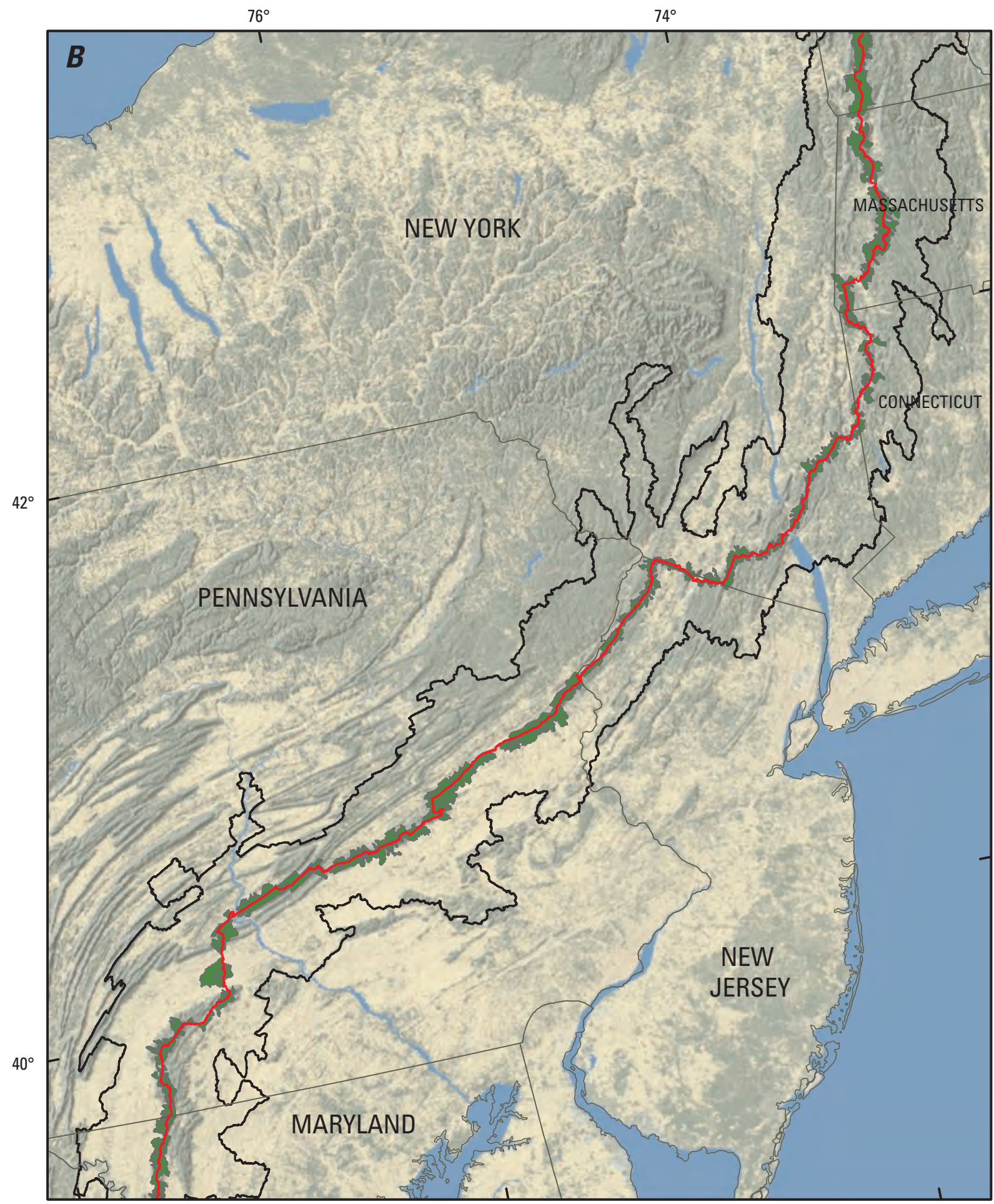

State-line boundaries from U.S. Geological Survey 1:2,000,000-scale digital data Albers Conic projection, NAD 1983

Catchment boundaries from National Hydrography Dataset Plus (U.S. Environmental Protection Agency, 2006a Physical-map background from the National Park Servic

EXPLANATION Natural Earth physical map, available online from ESRI (2009)
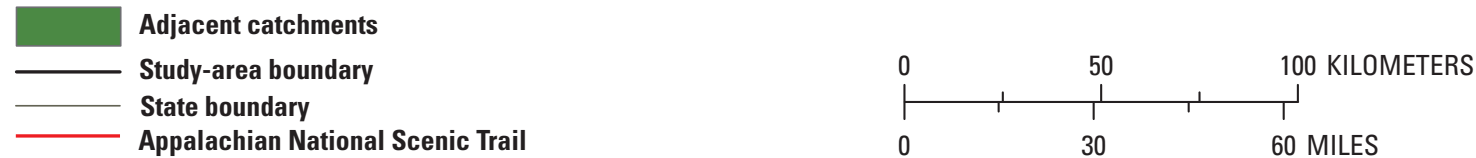

Figure 12. - Continued 


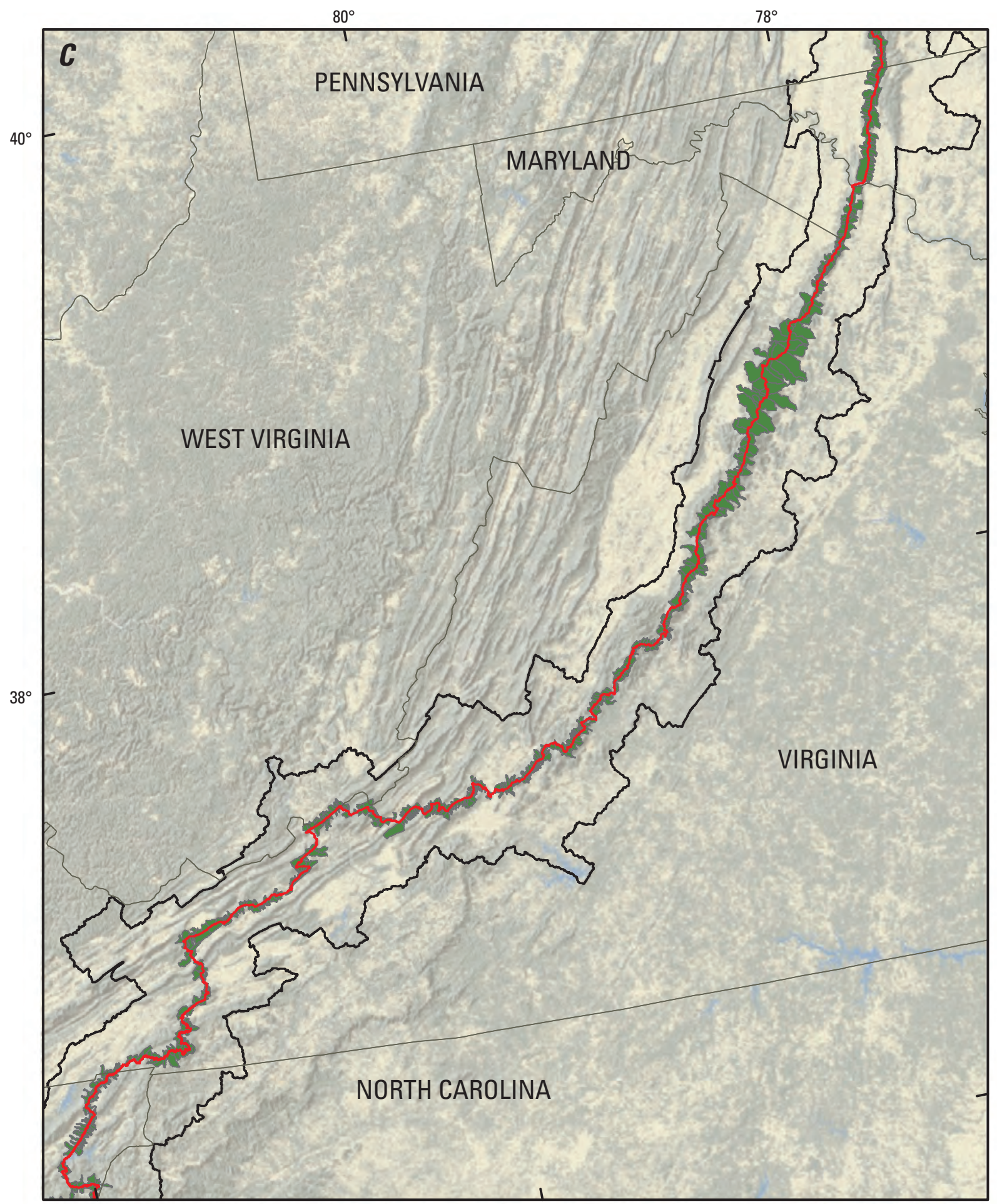

State-line boundaries from U.S. Geological Survey 1:2,000,000-scale digital data Albers Conic projection, NAD 1983

\section{EXPLANATION}

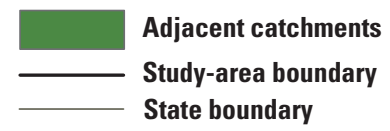

Appalachian National Scenic Trail
Catchment boundaries from National Hydrography Dataset Plus (U.S. Environmental Protection Agency, 2006a) Physical-map background from the National Park Service Natural Earth physical map, available online from ESRI (2009)

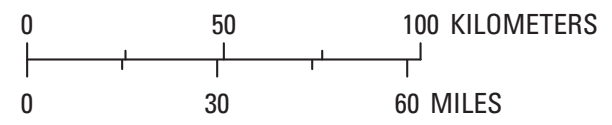

Figure 12. - Continued 


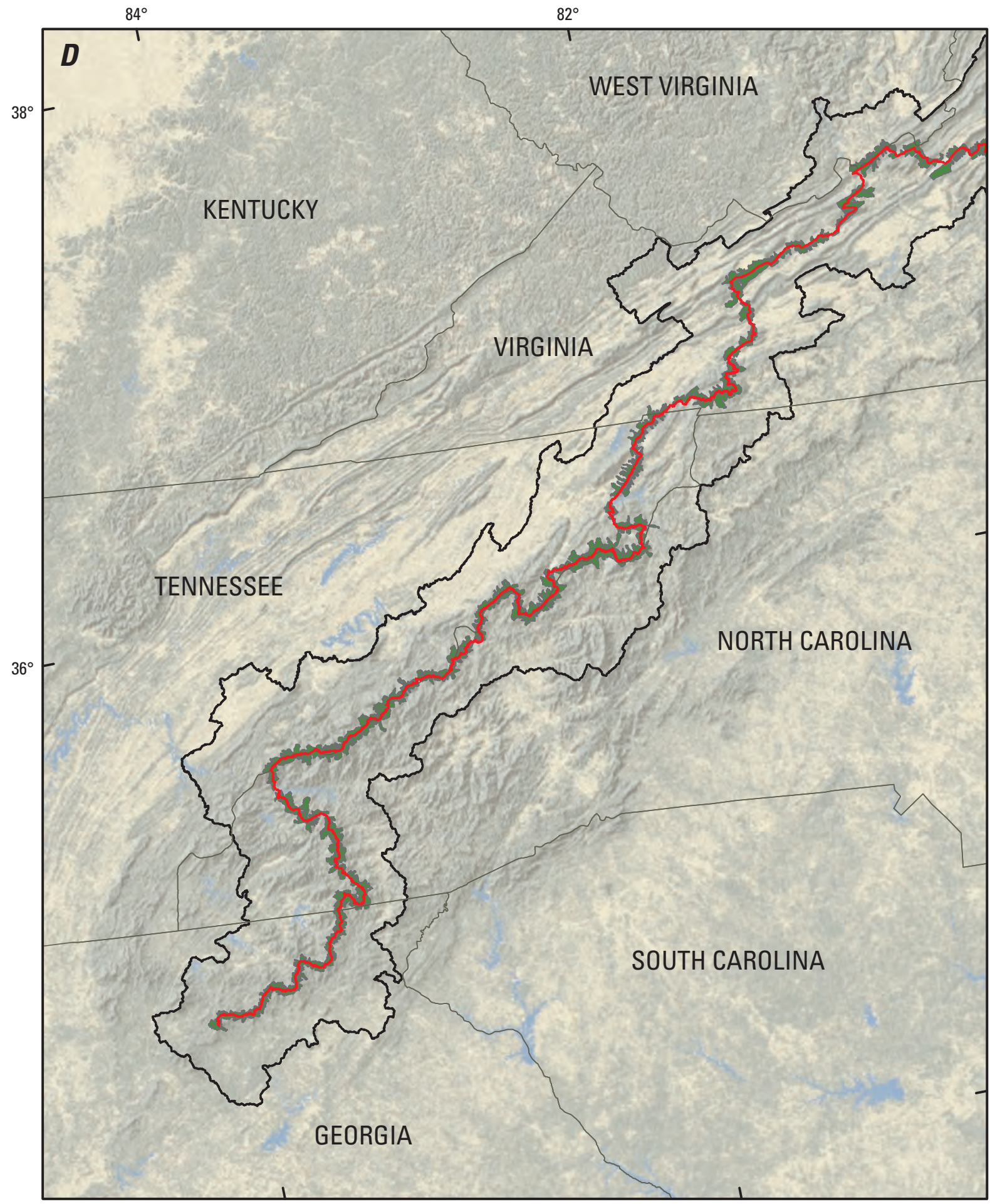

State-line boundaries from U.S. Geological Survey 1:2,000,000-scale digital data Albers Conic projection, NAD 1983

\section{EXPLANATION}

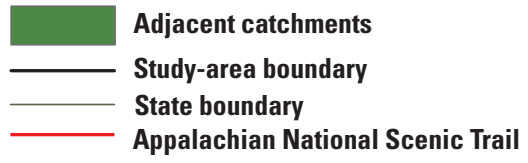

Catchment boundaries from National Hydrography Dataset Plus (U.S. Environmental Protection Agency, 2006a) Physical-map background from the National Park Service Natural Earth physical map, available online from ESRI (2009)

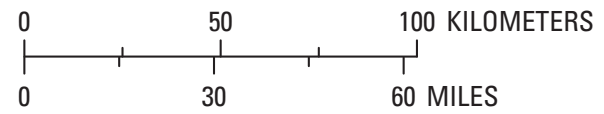

Figure 12. - Continued 


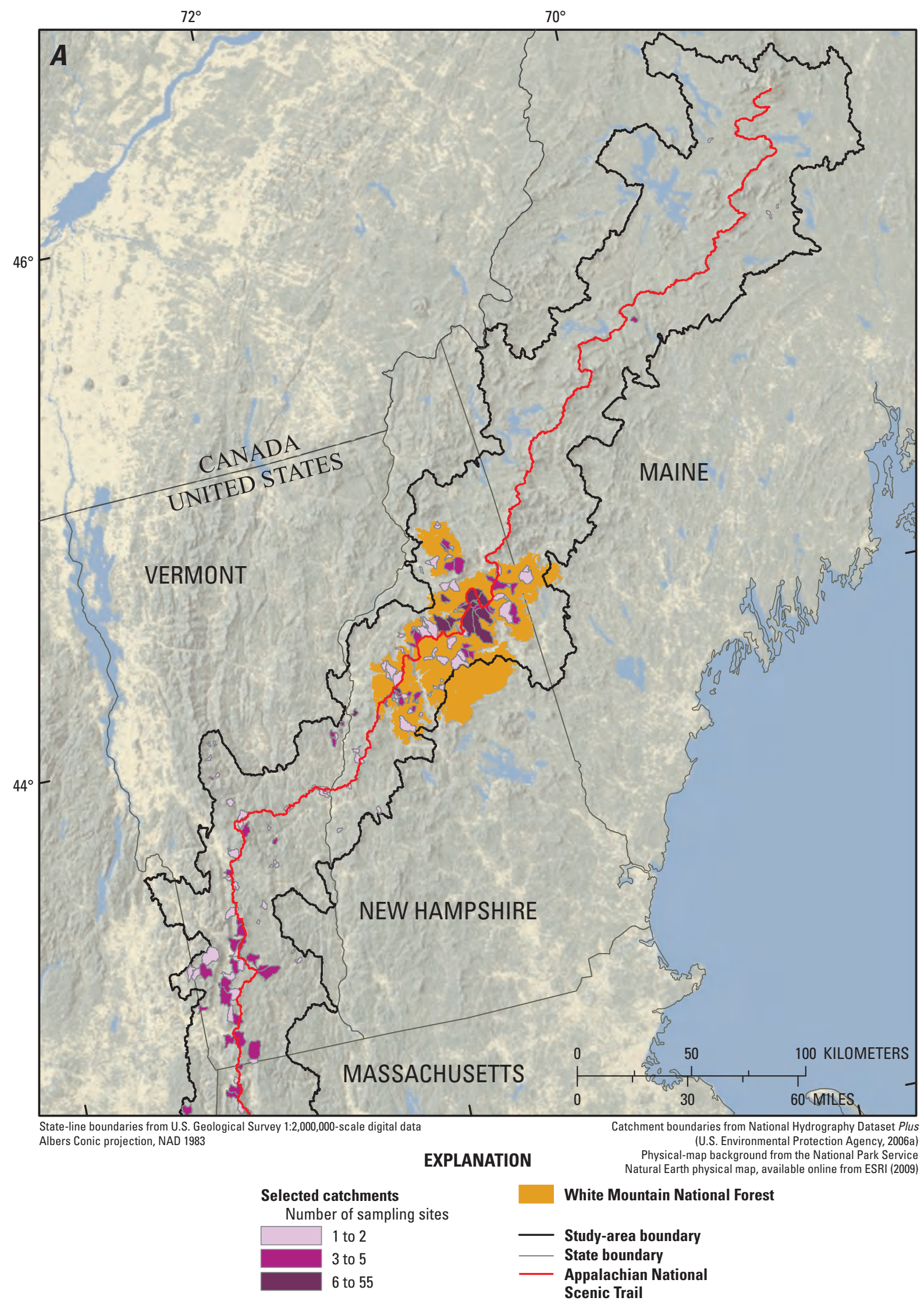

Figure 13. The spatial distribution of and the number of sampling sites in National Hydrography Dataset Plus (NHD Plus) catchments used in the level 1 inventory of first- and second-order streams along the Appalachian National Scenic Trail, $A$, Maine to Vermont, $B$, Massachusetts to Maryland, C, Maryland to Virginia, and D, Virginia to Georgia. 


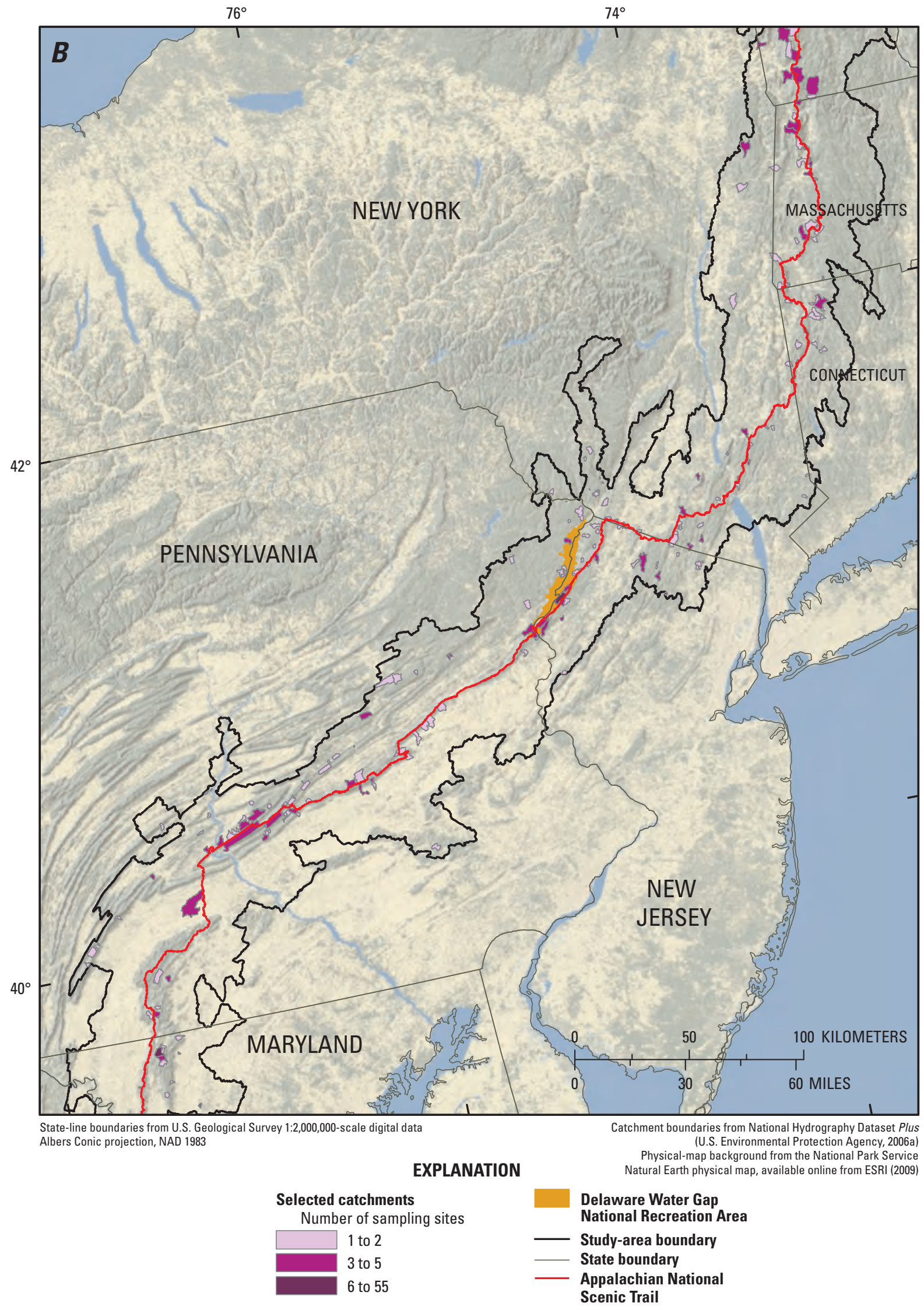

Figure 13. - Continued 


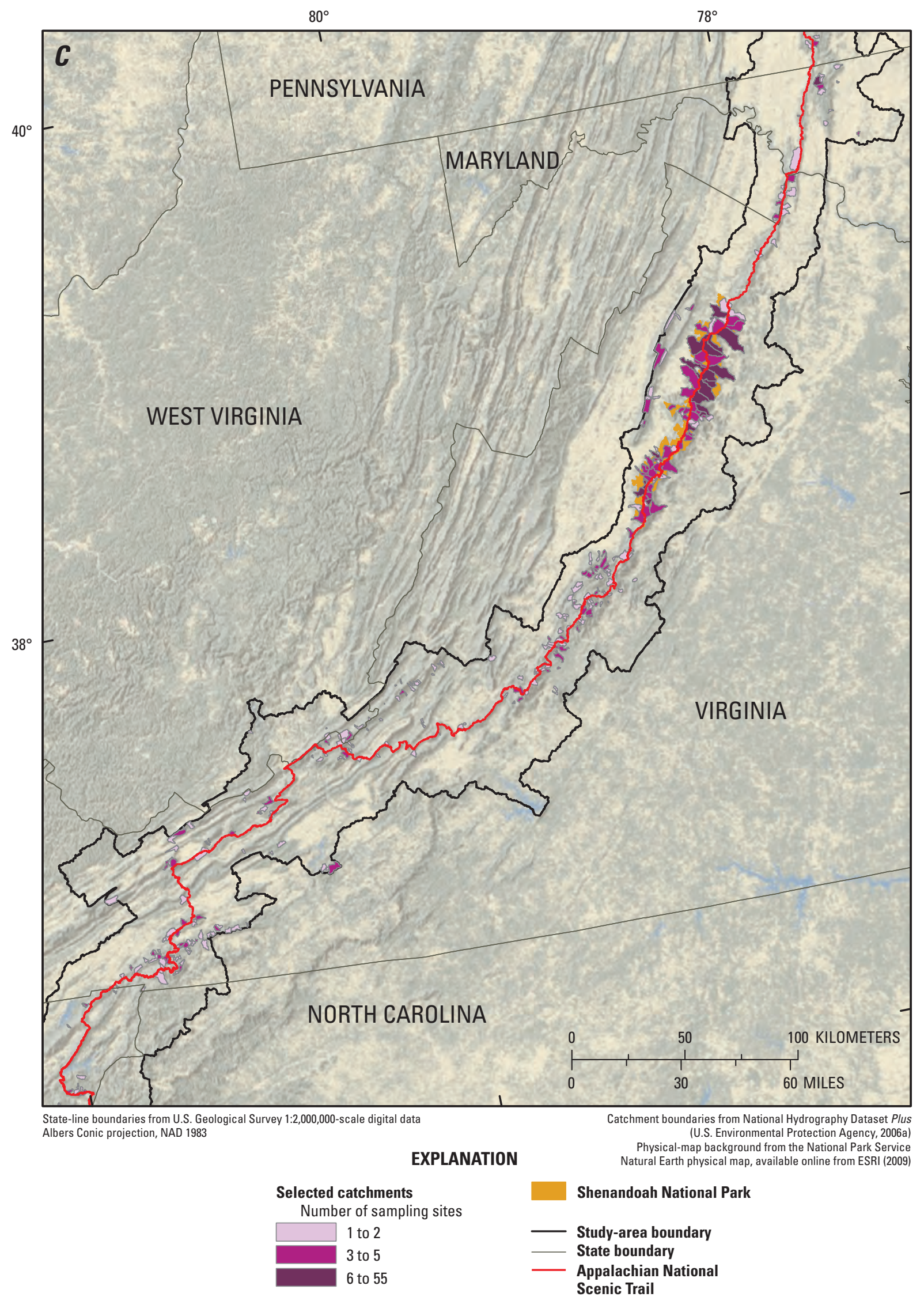

Figure 13. - Continued 


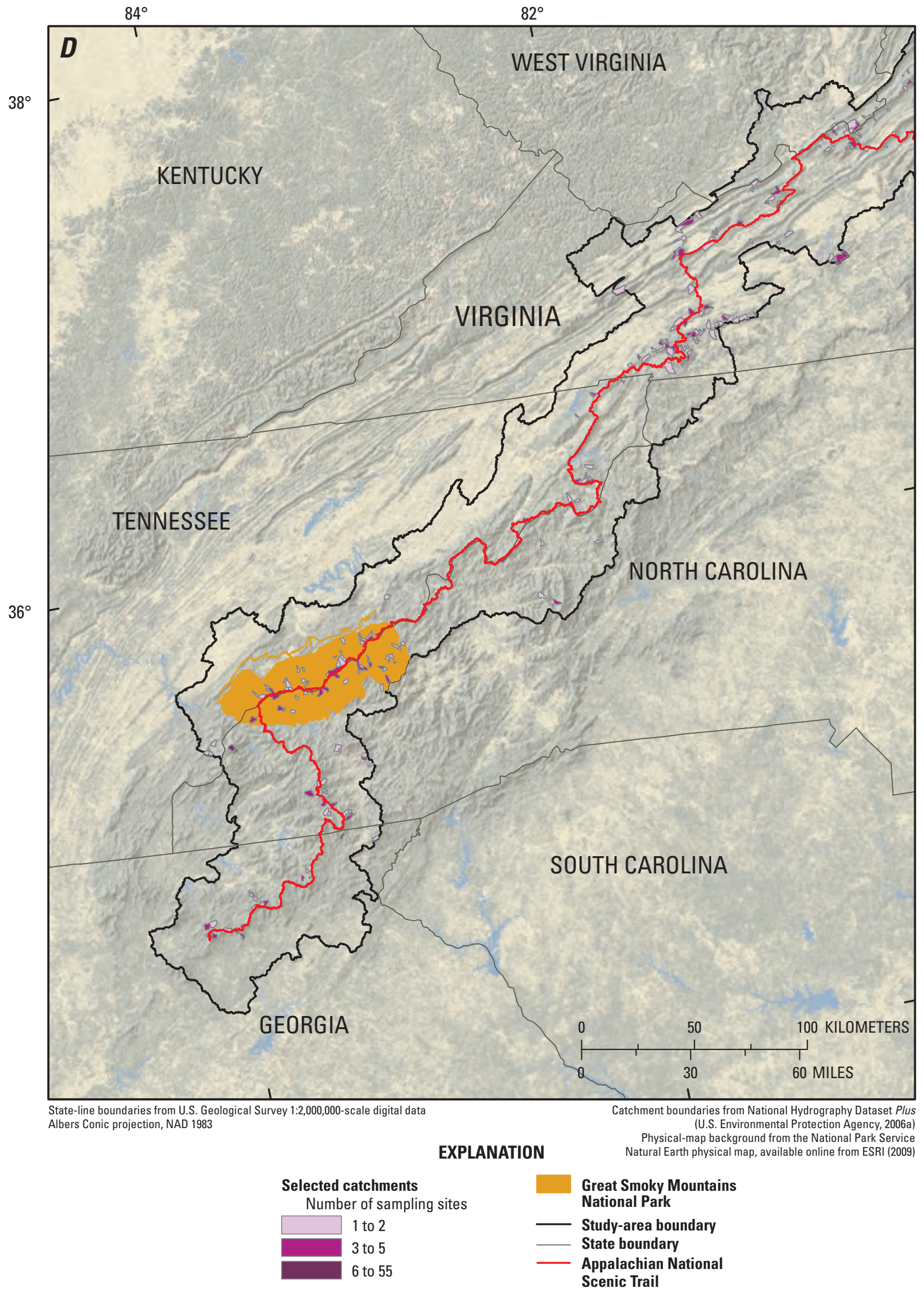

Figure 13. - - Continued 
Table 4. Threshold values, by subregion, of selected physical attributes used to screen nonadjacent sampling sites for inclusion in the water-quality summary of selected sampling sites along the Appalachian National Scenic Trail.

[Subregions are listed in approximate order from north to south; ft, feet]

\begin{tabular}{lccccc}
\hline $\begin{array}{c}\text { Subregion } \\
\text { (hydrologic unit name) }\end{array}$ & $\begin{array}{c}\text { Hydrologic } \\
\text { unit code }\end{array}$ & $\begin{array}{c}\text { Number of } \\
\text { adjacent } \\
\text { catchments }\end{array}$ & $\begin{array}{c}\text { Minimum stream } \\
\text { elevation } \\
\text { (ft) }\end{array}$ & $\begin{array}{c}\text { 75th percentile of } \\
\text { developed land cover } \\
\text { (percent) }\end{array}$ & $\begin{array}{c}\text { 75th percentile of } \\
\text { agricultural land cover } \\
\text { (percent) }\end{array}$ \\
\hline Penobscot & 0102 & 182 & 492 & 0 & 0.04 \\
Kennebec & 0103 & 73 & 487 & 0.03 & 0.10 \\
Androscoggin & 0104 & 74 & 1,015 & 0.01 & 0.05 \\
Saco & 0106 & 10 & 1,243 & 0.18 & 0.06 \\
Merrimack & 0107 & 36 & 1,012 & 0.04 & 0.37 \\
Connecticut & 0108 & 152 & 374 & 0.39 & 5.68 \\
Richelieu & 0201 & 41 & 658 & 0.71 & 5.92 \\
Upper Hudson & 0202 & 142 & 227 & 2.98 & 13.3 \\
Connecticut Coastal & 0110 & 136 & 347 & 1.25 & 10.8 \\
Lower Hudson-Long Island & 0203 & 52 & 0 & 1.47 & 0.83 \\
Delaware & 0204 & 141 & 291 & 0.71 & 17.2 \\
Susquehanna & 0205 & 129 & 332 & 0.12 & 26.8 \\
Potomac & 0207 & 199 & 220 & 0.65 & 27.7 \\
Lower Chesapeake & 0208 & 247 & 652 & 0.01 & 3.63 \\
Chowan-Roanoke & 0301 & 69 & 1,199 & 0.23 & 5.25 \\
Kanawha & 0505 & 147 & 1,895 & 0 & 15.8 \\
Upper Tennessee & 0601 & 597 & 1,318 & 0 & 1.06 \\
Middle Tennessee-Hiwassee & 0602 & 66 & 2,279 & 0 & 0.10 \\
Ogeechee-Savannah & 0306 & 26 & 2,728 & 0 & 0 \\
Apalachicola & 0313 & 37 & 2,323 & 0 & 0.12 \\
Alabama & 0315 & 9 & 1,904 & 0 & 0 \\
\hline
\end{tabular}

\section{Statistical Methods}

Selected data compiled for this study were statistically analyzed to characterize the water quality along the length of the Appalachian Trail using Version 9.3 of SAS (SAS Institute, 2008). Summary statistics were computed by robust Regression on Order Statistics which uses a probability plot of the logarithms of the data to account for datasets that include multiple detection limits (Helsel and Cohn, 1988; Helsel, 2005). In the robust Regression on Order Statistics method of analysis, detected values were used when available, while estimations were used for the censored portions of the distribution. In the combined dataset, each constituent had two to eight different detection limits, likely due to differences in laboratory analysis methods. Results less than the maximum detection limit for each constituent were considered estimated (Helsel, 2005). Dashed lines represent estimated values in box plots while estimated values in tables were reported by using italicized text.

Water-quality data were grouped by ecosections and by major geologic units, and the Kruskal-Wallis statistical test was used to determine if there were statistical differences in water-quality data within these groupings. If a significant difference was found, Tukey's multiple-comparison test was used to determine which group differed significantly (Helsel and Hirsch, 1992). Results from the Tukey's multiple-comparison tests are shown by use of letters on the figures in this report; groups having the same letter underneath them are not significantly different. Groups that contained fewer than five values are shown as boxplots but were not compared statistically. A Spearman rank correlation (rho) test was used to determine the strength of association between two variables and to identify environmental attributes that might have influenced water quality along and near the Appalachian Trail. Physical attributes (elevation, slope, and size of the drainage area) and land-cover, soils, temperature, and precipitation data were tested to determine the extent to which each variable is correlated with water-quality data. The level of significance for all tests was set at 0.05 . Significant rho values less than 0.4 are generally not discussed in this report because the correlations were considered weak. 


\section{Characterization of Selected Field Properties, Major-Ion Chemistry, Acid Neutralizing Capacity, and Nutrients}

Water-quality data from the selected sampling sites were aggregated, summarized, and used to describe the basic character of and variations in the water quality along the Appalachian Trail. Concentrations and relative proportions of solutes in surface waters are primarily determined by the types of sediments and bedrock underlying the surface waters, residence time, atmospheric deposition, and climate. These environmental attributes vary over the length of the Appalachian Trail, and water chemistry also varies as a reflection of these changes. Nine of the 17 USFS ecosections had sufficient sampling sites with relevant water-quality data and were used for describing variations in water quality along the Appalachian Trail. The nine ecosections were the White Mountains, Vermont-New Hampshire Upland, GreenTaconic-Berkshire Mountains, Lower New England, Hudson Valley, Northern Glaciated Allegheny Plateau, Northern Ridge and Valley, Blue Ridge Mountains, and Allegheny Mountains ecosections (fig. 7). Water-quality data from the White Mountains, Blue Ridge Mountains, and Allegheny Mountains ecosections typically demonstrated similar chemical concentrations that were markedly lower than concentrations measured in samples collected from the other ecosections.

Differences in selected physical attributes among ecosections may help to indicate factors that influence variations in water quality along the Appalachian Trail. Physical attributes of the catchments that contained selected sampling sites are summarized by ecosection in table 5 . The highest median elevations were in the southern (Allegheny Mountains and Blue Ridge Mountains, 2,495 and 2,474 ft respectively) and the northern (White Mountains and Green-TaconicBerkshire Mountains, 2,064 and 1,394 ft respectively) ecosections (table 5). Median slope values were greatest (steepest slopes) in the ecosections with the highest elevations, including the Allegheny Mountains, White Mountains, and Blue Ridge Mountains ecosections (table 5). The median percentage of developed land in drainage areas of catchments in the Lower New England ecosection was the highest ( 0.53 percent) (table 5). The Northern Ridge and Valley, Hudson Valley, Vermont-New Hampshire Upland, and Green-TaconicBerkshire Mountains ecosections contained the highest median percentages of agricultural land in the drainage areas of catchments (7.47, 4.09, 3.92, and 2.98, respectively) (table 5).

\section{Field Properties}

Temperature affects the life cycles and activity of aquatic organisms and the rates and equilibriums of biogeochemical reactions (Allen, 1995). Aggregated surface-water catchment temperature data for the 69 year period between March 1939 and November 2008 ranged from 2.6 to $25.2^{\circ} \mathrm{C}$ (table 6). Most temperature values $\left(56.7\right.$ percent) were less than $12^{\circ} \mathrm{C}$, which may be indicative of cool headwater streams. Water temperatures greater than $20^{\circ} \mathrm{C}$, which is generally considered an in stream upper limit for the protection of aquatic health, were recorded in 170 catchments (U.S. Environmental Protection Agency, 2006b). These warm temperatures were primarily observed between the months of July and September and were measured in all regions along the Appalachian Trail (including catchments with elevations greater than 2,500 ft). Water temperatures were related to season, elevation, and latitude. Catchments in the northern section of the Appalachian Trail generally had the coolest water temperatures in all seasons, whereas catchments in the central and southern sections of the Appalachian Trail generally had the warmest water temperatures in all seasons (table 7).

Dissolved oxygen is important in maintaining healthy stream biota because oxygen is necessary for the survival of many aquatic organisms, and is affected by many factors including ambient temperatures, atmospheric pressures, and ionic or biological activity. Catchment concentrations of dissolved oxygen ranged from 3.8 to $12.9 \mathrm{mg} / \mathrm{L}$, with a median value of $9.5 \mathrm{mg} / \mathrm{L}$ (table 6). Five catchments had concentrations of dissolved oxygen less than $6 \mathrm{mg} / \mathrm{L}$, which is generally considered the lower limit for the protection of aquatic health (U.S. Environmental Protection Agency, 2006b). Concentrations of dissolved oxygen appeared to be related to temporal variations, such as seasonal differences (table 7).

The $\mathrm{pH}$ of a water body is a measure of the Hydrogen ion $\left(\mathrm{H}^{+}\right)$concentration. $\mathrm{pH}$ helps to characterize the acid-base status of the water and has relevance to many water chemistry measures. Natural waters generally have $\mathrm{pH}$ values in the range of 6.5 to 8.5 (Hem, 1992). Catchment $\mathrm{pH}$ values ranged from 4.0 to 8.9 with a median value of 6.7 (table 6), with approximately 38 percent of the catchments (302) having $\mathrm{pH}$ values less than $6, \mathrm{pH}$ values of 6 , are generally considered an instream lower limit for the protection of aquatic health (U.S. Environmental Protection Agency, 2006b).

Statistical similarities and differences in median catchment $\mathrm{pH}$ values among the nine ecosections are shown in figure 14A. Median $\mathrm{pH}$ values from the White Mountain ecosection are the lowest and statistically unique among the other eight ecosections (median $\mathrm{pH}=6.1$ ) (fig. 14A, table 8). The Vermont-New Hampshire Upland, Green-Taconic-Berkshire Mountains, Lower New England, and Hudson Valley ecosections have the highest median catchment $\mathrm{pH}$ values of 7.1 to 7.4 (fig. 14A, table 8).

Specific conductance is a measure of the ability of water to conduct an electric current and is related to the concentration of dissolved solids (Hem, 1992) and is reported as microsiemens per centimeter $(\mu \mathrm{S} / \mathrm{cm})$. Median catchment specific conductance values ranged from 4.0 to $761 \mu \mathrm{S} / \mathrm{cm}$ with a median value of $23.8 \mu \mathrm{S} / \mathrm{cm}$ (table 6 ). Approximately 75 percent of the catchments had specific conductance values less than $50.0 \mu \mathrm{S} / \mathrm{cm}$ (table 6).

The White Mountains, Green-Taconic-Berkshire Mountains, Blue Ridge Mountains, and Allegheny Mountains 
Table 5. Summary statistics of selected physical attributes, by U.S. Forest Service ecological sections (ecosections), from catchments that contain selected sampling sites along the Appalachian National Scenic Trail.

[ft, feet]

\begin{tabular}{|c|c|c|c|c|}
\hline Ecological section & $\begin{array}{l}\text { Number of } \\
\text { catchments }\end{array}$ & Minimum & Median & Maximum \\
\hline & & \multicolumn{3}{|c|}{ Elevation (ft) } \\
\hline White Mountains & 82 & 712 & 2,064 & 3,950 \\
\hline Vermont-New Hampshire Upland & 25 & 430 & 971 & 1,985 \\
\hline Green-Taconic-Berkshire Mountains & 71 & 689 & 1,394 & 2,818 \\
\hline Lower New England & 36 & 381 & 833 & 1,490 \\
\hline Hudson Valley & 30 & 302 & 722 & 1,332 \\
\hline Northern Glaciated Allegheny Plateau & 13 & 548 & 873 & 1,158 \\
\hline Northern Ridge and Valley & 57 & 417 & 804 & 1,703 \\
\hline Blue Ridge Mountains & 369 & 522 & 2,474 & 5,351 \\
\hline \multirow[t]{2}{*}{ Allegheny Mountains } & 88 & 955 & 2,495 & 4,091 \\
\hline & & \multicolumn{3}{|c|}{ Slope } \\
\hline White Mountains & 82 & 0.00 & 0.06 & 0.20 \\
\hline Vermont-New Hampshire Upland & 22 & 0.00 & 0.03 & 0.13 \\
\hline Green-Taconic-Berkshire Mountains & 81 & 0.00 & 0.03 & 0.11 \\
\hline Lower New England & 37 & 0.00 & 0.02 & 0.08 \\
\hline Hudson Valley & 20 & 0.00 & 0.02 & 0.09 \\
\hline Northern Glaciated Allegheny Plateau & 14 & 0.01 & 0.03 & 0.12 \\
\hline Northern Ridge and Valley & 45 & 0.00 & 0.01 & 0.08 \\
\hline Blue Ridge Mountains & 330 & 0.01 & 0.07 & 0.35 \\
\hline \multirow[t]{2}{*}{ Allegheny Mountains } & 88 & 0.01 & 0.05 & 0.19 \\
\hline & & \multicolumn{3}{|c|}{ Percentage of developed land cover } \\
\hline White Mountains & 82 & 0.00 & 0.00 & 1.08 \\
\hline Vermont-New Hampshire Upland & 22 & 0.00 & 0.13 & 6.45 \\
\hline Green-Taconic-Berkshire Mountains & 81 & 0.00 & 0.38 & 20.0 \\
\hline Lower New England & 37 & 0.00 & 0.53 & 15.1 \\
\hline Hudson Valley & 20 & 0.00 & 0.41 & 27.2 \\
\hline Northern Glaciated Allegheny Plateau & 14 & 0.00 & 0.03 & 0.41 \\
\hline Northern Ridge and Valley & 45 & 0.00 & 0.05 & 23.6 \\
\hline Blue Ridge Mountains & 330 & 0.00 & 0.00 & 10.0 \\
\hline \multirow[t]{2}{*}{ Allegheny Mountains } & 88 & 0.00 & 0.00 & 3.08 \\
\hline & & \multicolumn{3}{|c|}{ Percentage of agricultural land cover } \\
\hline White Mountains & 82 & 0.00 & 0.01 & 5.40 \\
\hline Vermont-New Hampshire Upland & 22 & 0.08 & 3.92 & 35.5 \\
\hline Green-Taconic-Berkshire Mountains & 81 & 0.00 & 2.98 & 24.0 \\
\hline Lower New England & 37 & 0.00 & 0.64 & 17.0 \\
\hline Hudson Valley & 20 & 0.16 & 4.09 & 25.3 \\
\hline Northern Glaciated Allegheny Plateau & 14 & 0.05 & 0.17 & 3.98 \\
\hline Northern Ridge and Valley & 45 & 0.00 & 7.47 & 67.0 \\
\hline Blue Ridge Mountains & 330 & 0.00 & 0.19 & 41.1 \\
\hline Allegheny Mountains & 88 & 0.00 & 0.24 & 17.1 \\
\hline
\end{tabular}


Table 6. Summary statistics of concentrations of selected water-quality constituents from catchments that contain selected sampling sites along the Appalachian National Scenic Trail.

$\left[{ }^{\circ} \mathrm{C}\right.$, degrees Celsius; $\mathrm{mg} / \mathrm{L}$, milligrams per liter; $\mu \mathrm{S} / \mathrm{cm}$, microsiemens per centimeter at 25 degrees Celsius; $\mu \mathrm{eq} / \mathrm{L}$, microequivalents per liter; $<$, less than, italic text indicates estimated values]

\begin{tabular}{|c|c|c|c|c|c|c|c|}
\hline $\begin{array}{l}\text { Property or constituent } \\
\text { (reporting units) }\end{array}$ & $\begin{array}{l}\text { Number of } \\
\text { catchments }\end{array}$ & $\begin{array}{l}\text { Minimum } \\
\text { value }\end{array}$ & $\begin{array}{c}\text { 25th } \\
\text { percentile }\end{array}$ & $\begin{array}{l}\text { Median } \\
\text { value }\end{array}$ & Mean value & $\begin{array}{c}\text { 75th } \\
\text { percentile }\end{array}$ & $\begin{array}{l}\text { Maximum } \\
\text { value }\end{array}$ \\
\hline \multicolumn{8}{|c|}{ Field properties } \\
\hline Dissolved oxygen $(\mathrm{mg} / \mathrm{L})$ & 336 & 3.8 & 8.8 & 9.5 & 9.5 & 10.2 & 12.9 \\
\hline pH (standard units) & 790 & 4.0 & 6.2 & 6.7 & 6.6 & 7.1 & 8.9 \\
\hline \multicolumn{8}{|c|}{ Major ions } \\
\hline Bicarbonate (mg/L) & 163 & 0.26 & 3.55 & 9.64 & 22.9 & 24.9 & 262.0 \\
\hline Calcium (mg/L) & 585 & 0.19 & 0.83 & 1.46 & 3.36 & 2.92 & 81.2 \\
\hline Chloride (mg/L) & 656 & 0.20 & 0.53 & 0.78 & 2.76 & 1.85 & 150.0 \\
\hline Silica $\left(\mathrm{mg} / \mathrm{L}\right.$ as $\left.\mathrm{SiO}_{2}\right)$ & 399 & 0.25 & 0.60 & 1.18 & 9.76 & 4.99 & 207.7 \\
\hline Sodium $(\mathrm{mg} / \mathrm{L})$ & 573 & 0.21 & 0.65 & 1.01 & 1.94 & 1.70 & 84.0 \\
\hline Sulfate (mg/L) & 573 & 0.29 & 2.07 & 3.41 & 5.08 & 5.50 & 138.5 \\
\hline \multicolumn{8}{|c|}{ Nutrients } \\
\hline Ammonia (mg/L as N) & 283 & $<0.01$ & $<0.01$ & 0.016 & 0.050 & 0.038 & 4.00 \\
\hline Nitrate (mg/L as N) & 365 & $<0.008$ & 0.045 & 0.143 & 0.301 & 0.356 & 4.52 \\
\hline Total nitrogen (mg/L as $\mathrm{N})$ & 153 & $<0.05$ & 0.193 & 0.350 & 0.485 & 0.567 & 7.10 \\
\hline Total phosphorus (mg/L as $\mathrm{P}$ ) & 215 & $<0.004$ & 0.009 & 0.018 & 0.052 & 0.034 & 4.20 \\
\hline
\end{tabular}

ecosections had the lowest median specific conductance values, which ranged from 17.7 to $25.8 \mu \mathrm{S} / \mathrm{cm}$. The median specific conductance value from the Blue Ridge Mountains ecosection was the lowest when compared to the other ecosections. In contrast, the Vermont-New Hampshire Upland, Lower New England, Hudson Valley, Northern Glaciated Allegheny Plateau, and the Northern Ridge and Valley ecosections had higher median specific conductance values, which ranged from 41.0 to $108.1 \mu \mathrm{S} / \mathrm{cm}$ (fig. $14 \mathrm{~B}$, table 8).

\section{Major lons}

Major ions summarized in this report are common constituents dissolved in most natural waters and include bicarbonate, calcium, chloride, fluoride, magnesium, nitrate, potassium, silica, sodium, and sulfate (table 6). Median catchment concentrations of cations (calcium, magnesium, sodium, and potassium) were less than $1.5 \mathrm{mg} / \mathrm{L}$ and ranged from 0.47 to $1.46 \mathrm{mg} / \mathrm{L}$ (table 6). Median catchment concentrations of anions (bicarbonate, chloride, fluoride, nitrate, and sulfate) ranged more widely than those of cations; all medians were less than $10 \mathrm{mg} / \mathrm{L}$ and ranged from less than 0.08 to $9.64 \mathrm{mg} / \mathrm{L}$ (table 6 ).

Major-ion concentrations were compiled to develop water types. Water types can be an efficient way to describe variations in bulk water chemistry and also can be useful in identifying waters that have been contaminated from road salt or deposition. Water types were calculated based on the percentage of milliequivalents of the major ions present within each sample. In most samples compiled for this study, no one cation composed more than 50 percent of the total cations. Sulfate was the most frequently detected predominant anion. Consequently, calcium-magnesium mixed, sulfate was the most frequently determined water type. In the Lower New England and Hudson Valley ecosections however, calcium-bicarbonate was the most frequently calculated water type. 
Table 7. Water temperature and dissolved oxygen concentrations by U.S. Forest Service ecological sections (ecosections) and by season from selected sampling sites along the Appalachian National Scenic Trail.

$\left[{ }^{\circ} \mathrm{C}\right.$, degrees Celsius; --, insufficient data (fewer than 5 reported values); mg/L, milligrams per liter]

\begin{tabular}{lcccc}
\hline \multicolumn{1}{c}{ Ecological section } & January to March & April to June & July to September & October to December \\
\hline & \multicolumn{4}{c}{ Water temperature $\left({ }^{\circ} \mathrm{C}\right)$} \\
White Mountains & 0.5 & 7.8 & 13.3 & 3.9 \\
Vermont-New Hampshire Upland & 0.0 & 10.0 & 15.6 & 4.0 \\
Green-Taconic-Berkshire Mountains & 1.0 & 12.0 & 16.0 & 5.6 \\
Lower New England & 1.0 & 13.0 & 18.0 & 7.0 \\
Hudson Valley & 4.1 & 14.0 & 17.9 & 9.5 \\
Northern Glaciated Allegheny Plateau & -- & 14.3 & 19.2 & -- \\
Northern Ridge and Valley & 4.6 & 12.0 & 17.0 & 8.8 \\
Blue Ridge Mountains & 5.0 & 12.1 & 18.0 & 9.5 \\
Allegheny Mountains & 4.0 & 10.3 & 17.0 & 9.0 \\
& & Dissolved oxygen (mg/L) & \\
White Mountains & -- & 10.4 & 9.4 & 12.2 \\
Vermont-New Hampshire Upland & 13.6 & 10.7 & 8.9 & 12.3 \\
Green-Taconic-Berkshire Mountains & 14.0 & 10.0 & 9.2 & 11.5 \\
Lower New England & 11.1 & 9.2 & 8.0 & 9.8 \\
Hudson Valley & 13.4 & 10.0 & 8.7 & 11.4 \\
Northern Glaciated Allegheny Plateau & -- & -- & -- & - \\
Northern Ridge and Valley & 12.4 & 10.4 & 8.8 & 11.0 \\
Blue Ridge Mountains & 11.9 & 9.9 & 8.0 & 8.4 \\
Allegheny Mountains & 11.3 & 10.0 & 10.0 & 10.1 \\
\hline
\end{tabular}

Median concentrations of calcium, magnesium, and sodium (cations) from the Hudson Valley and Lower New England ecosections are among the highest compared to the other ecosections (figs. 14D-G) (table 8). One notable exception is catchment concentrations of magnesium in the Vermont-New Hampshire Upland and Green-TaconicBerkshire Mountains ecosections of 8.30 and $5.75 \mathrm{mg} / \mathrm{L}$, respectively. Median catchment concentrations of calcium, magnesium, and sodium in the White Mountains, Blue Ridge Mountains, and Allegheny Mountains are among the lowest compared to the other ecosections (figs. 14D-F) (table 8). The White Mountains ecosection also had the lowest median catchment concentration of potassium and was statistically similar only to the Northern Glaciated Allegheny Plateau ecosection (fig. 14G).

Catchment concentrations of common anions were similar to those of cations - generally lowest in the White Mountains, Blue Ridge Mountains, and Allegheny Mountains (figs. 14H-J, table 8). Catchment concentrations of sulfate in these three ecosections were lower than in the other six ecosections and statistically unique in the Blue Ridge Mountain ecosection (fig. 14H). Catchment concentrations of chloride in these three ecosections also were lower than in the other six ecosections and statistically unique in the White Mountains ecosection (fig. 14I). Catchment concentrations of chloride and sulfate in the Hudson Valley and Lower New England ecosections are generally higher than in the other ecosections (figs. 14H-I, table 8). Catchment concentrations of nitrate were generally lower than concentrations of sulfate and chloride, and the medians for five of the nine ecosections were estimated (fig. 14J, table 8). Catchment concentrations of nitrate were highest in the Northern Ridge and Valley, Green-Taconic-Berkshire Mountains, and Vermont-New Hampshire Upland ecosections: $0.416,0.330$ and $0.261 \mathrm{mg} / \mathrm{L}$, respectively (fig. 14J, table 8).

Overall, major ion concentrations are lower in the White Mountains, Blue Ridge Mountains, and Allegheny Mountains ecosections and higher concentrations in the Lower New England and Hudson Valley ecosections. The VermontNew Hampshire Upland, Green-Taconic-Berkshire Mountains, Northern Glaciated Allegheny Plateau, and Northern Ridge and Valley ecosections represent the transition zones along the Appalachian Trail between the regions of highest and lowest elevation (table 5). The catchment concentrations of most major ions in these four transitional ecosections are generally lower than or similar to catchment concentrations from the Hudson Valley and Lower New England ecosections and greater than catchment concentrations from the White Mountains, Blue Ridge Mountains, and Allegheny Mountains ecosections. 
Table 8. Summary statistics of selected water-quality constituents by U.S. Forest Service ecological sections (ecosections) from catchments that contain selected sampling sites in headwater streams along the Appalachian National Scenic Trail.

$[\mu \mathrm{S} / \mathrm{cm}$, microsiemens per centimeter at 25 degrees Celsius; $\mu \mathrm{eq} / \mathrm{L}$, microequivalents per liter; $\mathrm{mg} / \mathrm{L}$, milligrams per liter; $<$, less than; italic text indicates estimated values]

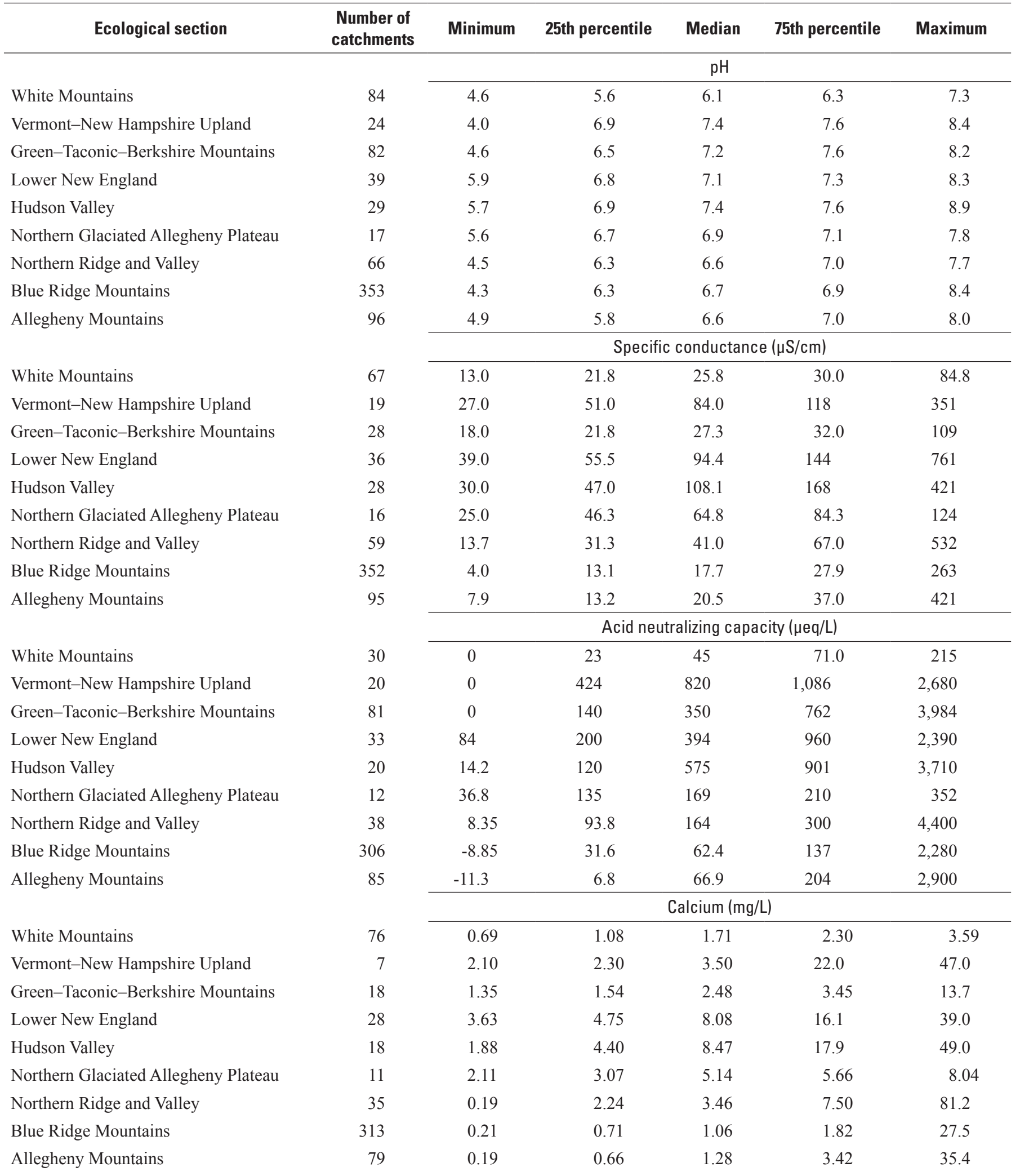


Table 8. Summary statistics of selected water-quality constituents by U.S. Forest Service ecological sections (ecosections) from catchments that contain selected sampling sites in headwater streams along the Appalachian National Scenic Trail.-Continued

$[\mu \mathrm{S} / \mathrm{cm}$, microsiemens per centimeter at 25 degrees Celsius; $\mu \mathrm{eq} / \mathrm{L}$, microequivalents per liter; $\mathrm{mg} / \mathrm{L}$, milligrams per liter; $<$, less than; italic text indicates estimated values]

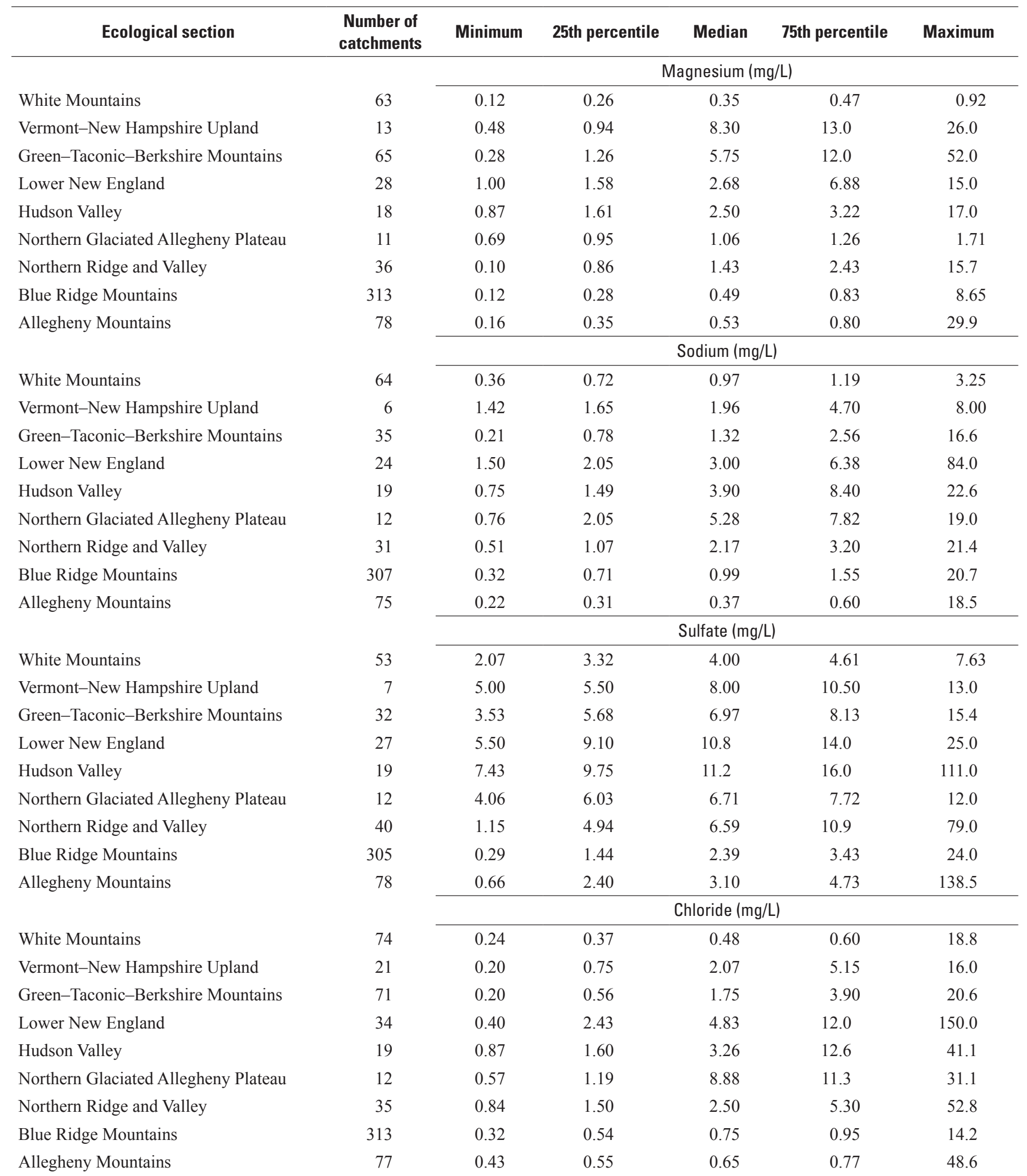


Table 8. Summary statistics of selected water-quality constituents by U.S. Forest Service ecological sections (ecosections) from catchments that contain selected sampling sites in headwater streams along the Appalachian National Scenic Trail.—Continued

$[\mu \mathrm{S} / \mathrm{cm}$, microsiemens per centimeter at 25 degrees Celsius; $\mu \mathrm{eq} / \mathrm{L}$, microequivalents per liter; $\mathrm{mg} / \mathrm{L}$, milligrams per liter; $<$, less than; italic text indicates estimated values]

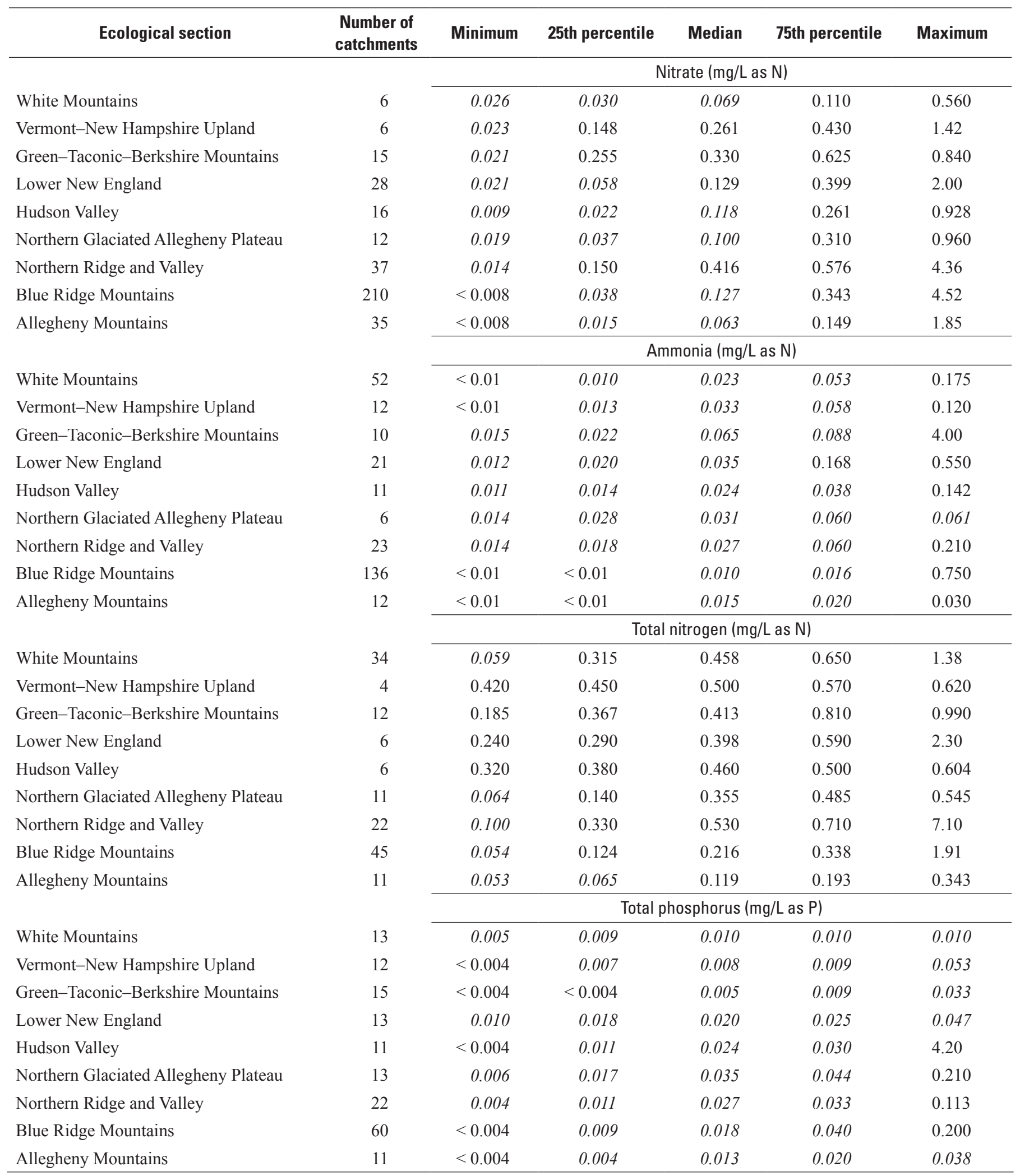



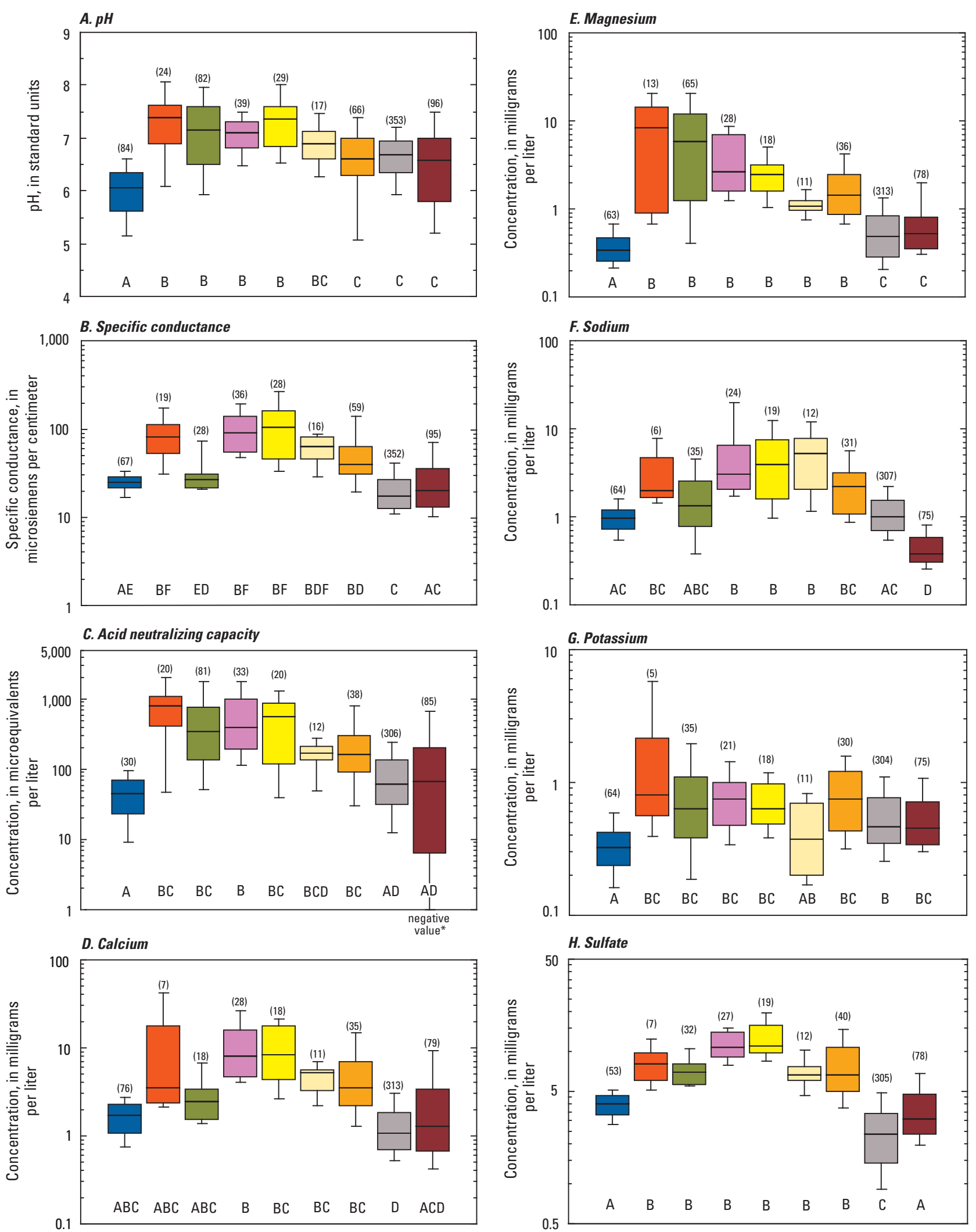

Figure 14. Comparisons of concentrations of $A, \mathrm{pH}, B$, specific conductance, $C$, acid neutralizing capacity, $D$, calcium, $E$, magnesium, $F$, sodium, $G$, potassium, $H$, sulfate, $I$, chloride, $J$, nitrate, $K$, ammonia, $L$, total nitrogen, and $M$, total phosphorus, by U.S. Forest Service ecological sections (ecosections), from catchments that contain selected first- and second-order streams along the Appalachian National Scenic Trail. Ecosections are displayed left to right in approximate north to south order. 

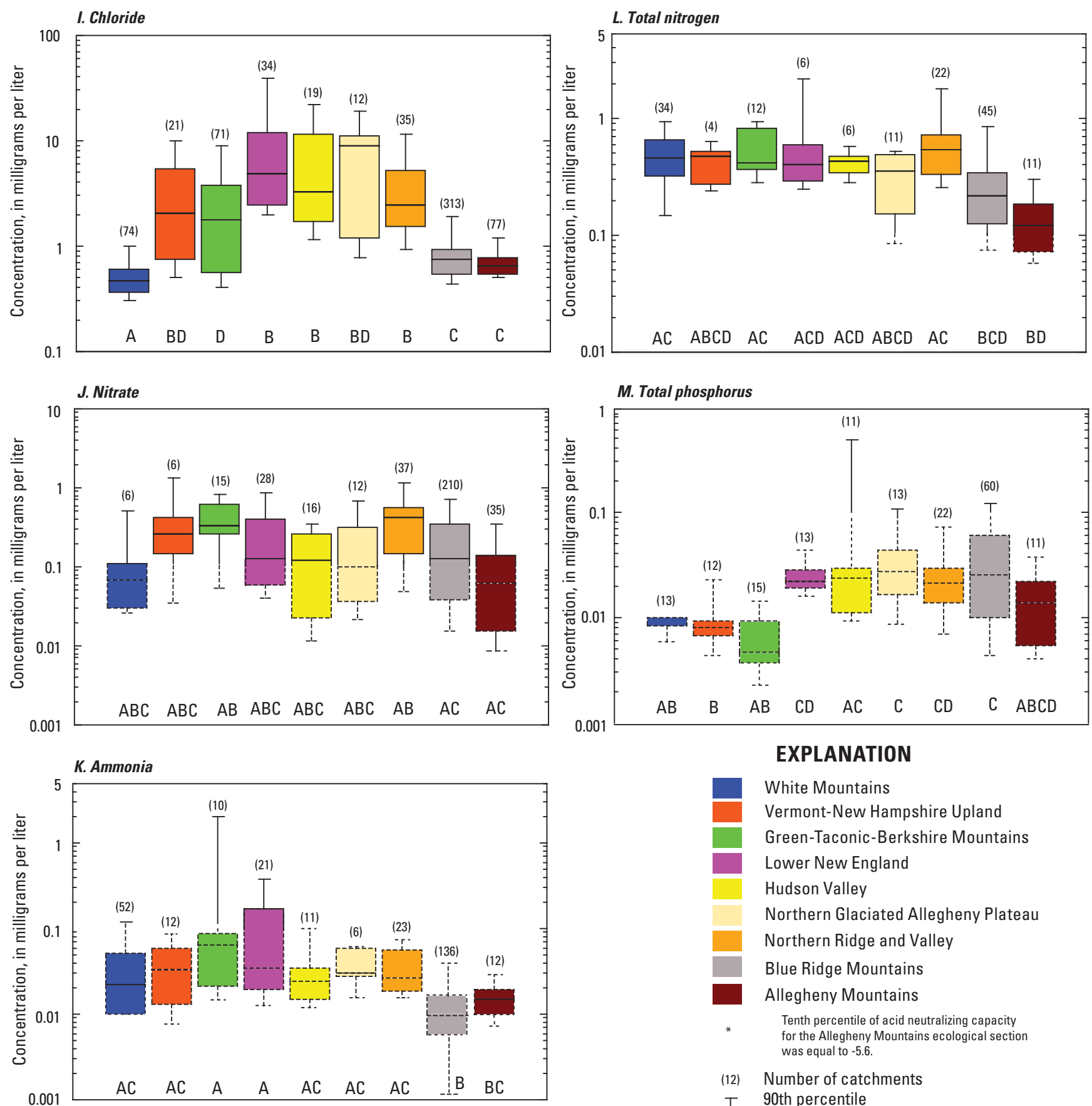

White Mountains

Vermont-New Hampshire Upland

Green-Taconic-Berkshire Mountains

Lower New England

Hudson Valley

Northern Glaciated Allegheny Plateau

Northern Ridge and Valley

Blue Ridge Mountains

Allegheny Mountains

Tenth percentile of acid neutralizing capacity for the Allegheny Mountains ecological section was equal to -5.6 .

(12) Number of catchments

T 90th percentile

75th percentile

50th percentile (median)

25th percentile

10th percentile

AC Statistical group from nonparametric Tukey's multiple-comparison test (groups with the same letter are not significantly different)

Estimated, less than maximum detection limit (multiple detection limits within data)

Figure 14. - Continued 


\section{Acid Neutralizing Capacity}

Acid neutralizing capacity (ANC) is the capacity of a solution, including solutes plus particulates in an unfiltered water sample, to react with and neutralize acid (Rounds, 2006). ANC values, measured in microequivalents per liter $(\mu \mathrm{eq} / \mathrm{L})$ help to characterize the acid-base chemistry of water and indicate a net strong base in solution if ANC is positive or a net strong acid if the ANC value is negative. Higher ANC values indicate greater ability to resist acidic inputs from sources such as acid deposition. Catchment values for ANC ranged from -11.3 to $4,400 \mu \mathrm{eq} / \mathrm{L}$, with a median $\mathrm{ANC}$ value for the entire Appalachian Trail of $98.7 \mu \mathrm{eq} / \mathrm{L}$ (table 6).

There were distinct differences in catchment ANC values among the ecosections (fig. 14C). As with $\mathrm{pH}$, the median ANC value for all catchments in the White Mountains ecosection was the lowest of all the ecosections, with a median value of $45.0 \mu \mathrm{eq} / \mathrm{L}$ (table 8). Median catchment $\mathrm{ANC}$ values from the Blue Ridge Mountains and the Allegheny Mountains were statistically similar and among the lowest: 62.4 and $66.9 \mu \mathrm{eq} / \mathrm{L}$, respectively (fig. $14 \mathrm{C}$, table 8 ). Catchments in the Vermont-New Hampshire Upland ecosection had the highest median ANC value $(820 \mu \mathrm{eq} / \mathrm{L})($ table 8$)$. The catchments from the Green-Taconic-Berkshire Mountains, Lower New England, and Hudson Valley ecosections also had relatively high median ANC values $(350,394$, and $575 \mu \mathrm{eq} / \mathrm{L}$, respectively) (table 8). The three ecosections (White Mountains, Blue Ridge Mountains, and Allegheny Mountains) that had the lowest catchment ANC values also had the lowest catchment concentrations of most major ions (figs. 14D-J) (table 8).

For comparison purposes, catchment ANC values were divided into three categories: ANC values less than zero were defined as acidic, ANC values between 0 and $50 \mu$ eq/L were classified as sensitive, and ANC values greater than $50 \mu \mathrm{eq} / \mathrm{L}$ were classified as insensitive (Kahl and Scott, 1988; Driscoll and others, 2001; Sullivan and others, 2007). Classification as sensitive and insensitive generally refers to the extent that the stream is susceptible to becoming acidic either seasonally or through event-driven episodic acidification. The percentages of catchments that had ANC values classified as acidic, sensitive, or insensitive are shown in table 9.

The ecosections with the most dilute watersWhite Mountains, Blue Ridge Mountains, and Allegheny Mountains - had the highest percentages of catchments classified as acidic or sensitive compared to all other ecosections (table 9). The Allegheny Mountains had the highest percentage of catchments classified as acidic (17.6 percent) while 1.6 of the catchments in the Blue Ridge Mountains ecosection were classified as acidic (table 9). The White Mountains ecosection had the highest percentage of catchments classified as sensitive (56.7) (table 9). The White Mountains ecosection contained no catchments that were classified as acidic; however, this may be the result of the titration methods most commonly used to determine ANC values in this ecosection. Most of the ANC data from the Blue Ridge and Allegheny Mountains ecosections were
Table 9. Comparison among U.S. Forest Service ecological sections (ecosections) of the percentages of catchments with acid neutralizing capacity classified as acidic (ANC less than or equal to $0 \mu \mathrm{eq} / \mathrm{L}$ ), sensitive (ANC greater than 0 and less than $50 \mu \mathrm{eq} / \mathrm{L}$ ), or insensitive (ANC equal to or greater than $50 \mu \mathrm{eq} / \mathrm{L}$ ).

[ $\mu$ eq/L, microequivalents per liter]

\begin{tabular}{|c|c|c|c|c|}
\hline \multirow[b]{2}{*}{ Ecological section } & \multirow{2}{*}{$\begin{array}{c}\text { Number } \\
\text { of catch- } \\
\text { ments }\end{array}$} & \multicolumn{3}{|c|}{ Percentage of catchments } \\
\hline & & Acidic & $\begin{array}{l}\text { Sen- } \\
\text { sitive }\end{array}$ & $\begin{array}{l}\text { Insen- } \\
\text { sitive }\end{array}$ \\
\hline White Mountains & 30 & 0 & 56.7 & 43.3 \\
\hline $\begin{array}{l}\text { Vermont-New Hampshire } \\
\text { Upland }\end{array}$ & 20 & 0 & 10 & 90 \\
\hline $\begin{array}{l}\text { Green-Taconic-Berkshire } \\
\text { Mountains }\end{array}$ & 81 & 0 & 9.9 & 90.1 \\
\hline Lower New England & 33 & 0 & 0 & 100 \\
\hline Hudson Valley & 20 & 0 & 15 & 85 \\
\hline $\begin{array}{l}\text { Northern Glaciated } \\
\text { Allegheny Plateau }\end{array}$ & 12 & 0 & 8.3 & 91.6 \\
\hline Northern Ridge and Valley & 38 & 0 & 13.2 & 86.8 \\
\hline Blue Ridge Mountains & 306 & 1.6 & 38.2 & 60.1 \\
\hline Allegheny Mountains & 85 & 17.6 & 29.4 & 52.9 \\
\hline
\end{tabular}

determined by use of Gran's method and therefore are useful in fully characterizing the ANC of these dilute waters. Few of the ANC data from the White Mountains ecosection were determined by use of Gran's method, and therefore low ANC values may be truncated or otherwise not fully determined. Previous investigations in the northeastern United States have shown that a substantial number of lakes are chronically acidic (Kahl and Scott, 1988; Charles and Christy, 2001). This information indicates that surface waters in the White Mountains ecosection are likely to be classified as acidic. The ANC data compiled for this inventory may under represent the extent of regions near or along the Appalachian Trail where noncarbonate alkalinity is a substantial contributor to ANC and where the ANC of streamwaters could be classified as acidic.

Surface waters that have ANC low enough to be classified as acidic or sensitive are prone to seasonal and (or) event driven periods where the water quality is detrimental to the health of aquatic and terrestrial ecosystems. For most forested headwater streams, ANC is generally lower during higher streamflow (Rice and Bricker, 1995; Driscoll and others, 2001; Lawrence and others, 2004). Changes in streamflow can initiate significant changes in the water chemistry through dilution and (or) inputs of ions from deposition. Research on lakes and streams near the Appalachian Trail has helped scientists determine the processes that govern seasonal or event driven episodic acidification. Literature on investigations conducted 
in the Northeast, which includes the White Mountains ecosection, conclude that base-cation dilution is commonly the most important contributor to loss in ANC, coupled with increases of nitrate and dissolved organic carbon (Charles and Christie, 1991; Wigington and others, 1996). In contrast, literature from studies conducted in the southern Appalachian Mountains, which includes the Blue Ridge Mountains and Allegheny Mountains ecosections, demonstrates that increases in sulfate, dissolved organic carbon, nitrate, and organic acids are more important than base-cation dilution in generating episodic acidification (Cook and others, 1994; Hyer and others, 1995; Deyton and others, 2009). Although streams in the White Mountains, Blue Ridge Mountains, and Allegheny Mountains ecosections are of similarly low ionic strength and are vulnerable to episodic acidification, the processes in the three ecosections that cause episodic acidification are distinctly different. Regional variations in watershed characteristics that influence the throughput and fluxes of ions - such as lithology, soil properties, and vegetation - likely play an important role in describing why the processes of episodic acidification are different between the ecosection in the north and ecosections in the south.

\section{Nutrients}

Nutrients (ammonia, nitrate, total nitrogen, and total phosphorus) in surface water are essential to aquatic life but need to be in appropriate concentrations. Excessively high concentrations of nitrogen can be toxic to fish and harmful to humans. High concentrations of phosphorus can produce an overgrowth of algae, which can degrade aquatic habitats. Source of excess nutrients are commonly associated with developed and agricultural land uses including urban runoff, pesticide use, effluent, and atmospheric deposition. In undeveloped areas, atmospheric deposition and the weathering of rocks and soils are typically the largest contributors (Dubrovsky and others, 2010). In first- and second-order streams along the Appalachian Trail, concentrations of nutrients are typically not high enough to be harmful to aquatic life. Concentrations of nutrients in streams along some regions of the Appalachian Trail may be evaluated through comparisons to estimated background concentrations and to regional nutrient criteria.

Catchment concentrations of ammonia were the lowest among the three nitrogen species with an overall median concentration of $0.016 \mathrm{mg} / \mathrm{L}$ (table 6). The highest median concentrations of ammonia were in catchments in the GreenTaconic-Berkshire Mountains ecosection $(0.065 \mathrm{mg} / \mathrm{L})$ (fig. 14K, table 8). Concentrations of total nitrogen were the highest among the three nitrogen species (table 6). Median concentrations of total nitrogen were similar along most of the Appalachian Trail and ranged from 0.355 to $0.530 \mathrm{mg} / \mathrm{L}$ for most ecosections (fig. 14L, table 8). The Blue Ridge Mountains and Allegheny Mountains ecosections were the exception; these two ecosections had lower median concentrations of total nitrogen $(0.216$ and $0.119 \mathrm{mg} / \mathrm{L}$, respectively; table 8).

Catchment concentrations of total phosphorus ranged from less than 0.004 to $4.20 \mathrm{mg} / \mathrm{L}$, with an estimated median catchment concentration of $0.018 \mathrm{mg} / \mathrm{L}$ (table 6). Median catchment concentrations of phosphorus are higher in the middle and southern ecosections than in the northern ecosections (fig. 14M, table 8). The region of the Appalachian Trail where concentrations of total phosphorus appeared to change is near the southernmost extent of the most recent glacial advance between the Green-Taconic-Berkshire Mountains and the Lower New England ecosections. Median catchment concentrations of phosphorus may be higher in the nonglaciated regions of the Appalachian Trail because more abundant deposits of weathered sediments may provide a source of suspended sediment, which typically entrains and transports phosphorus in the streams. Comparative evaluation of the average percentages listed in the State Soil Geographic database of clay and sand in the soil of each ecosection showed that the middle and southern ecosections contain more clay-rich soil, while the northern ecosections contain more sandy soil.

Catchment concentrations of nutrients from selected sampling sites in headwater streams along the Appalachian Trail were compared to estimated national background concentrations (Dubrovsky and others, 2010) (table 10). Estimated national background concentrations were based on data from streams across the Nation in areas with minimal or no development and included sites in semiarid and arid regions (Dubrovsky and others, 2010). Overall catchment concentrations of ammonia, nitrate, total nitrogen, and total phosphorus were lower at sites along the Appalachian Trail

Table 10. Comparison of median catchment concentrations of nutrients and the percentages of median concentrations greater than estimated national background concentrations from selected sampling sites along the Appalachian National Scenic Trail.

[mg/L, milligrams per liter; italic text indicates estimated values]

\begin{tabular}{lccc}
\hline Constituent & $\begin{array}{c}\text { Estimated } \\
\text { national } \\
\text { background } \\
\text { concentra- } \\
\text { tions } \\
\text { (mg/L) }\end{array}$ & $\begin{array}{c}\text { Median } \\
\text { catchment } \\
\text { concentra- } \\
\text { tions } \\
\text { (mg/L) }\end{array}$ & $\begin{array}{c}\text { Percentage } \\
\text { of catchment } \\
\text { concentrations } \\
\text { greater than } \\
\text { estimated national } \\
\text { background } \\
\text { concentrations }\end{array}$ \\
\hline Ammonia & 0.025 & 0.016 & 35.3 \\
Nitrate & 0.24 & 0.143 & 36.9 \\
Total nitrogen & 0.58 & 0.35 & 23.5 \\
Total phosphorus & 0.034 & 0.018 & 25.1 \\
\hline
\end{tabular}

${ }^{1}$ Estimates for national background concentrations are from Dubrovsky and others, 2010. 
as compared to estimated national background concentrations (table 10). However, on a smaller scale, the Vermont-New Hampshire Upland, Green-Taconic-Berkshire Mountains, Northern Glaciated Allegheny Plateau, and the Northern Ridge and Valley ecosections had median catchment concentrations of ammonia that were higher than estimated national background concentrations (tables 8 and 10). Additionally, the Vermont-New Hampshire Upland, Green-Taconic-Berkshire Mountains, and the Northern Ridge and Valley ecosections had median catchment concentrations of nitrate that were higher than estimated national background concentrations (tables 8 and 10).

The USEPA has developed recommended ecoregional criteria for total nitrogen and total phosphorus that are intended to approximate reference or background concentrations and serve as guidelines to protect against nutrient enrichment (U.S. Environmental Protection Agency, 2000; 2002b). The nutrient ecoregion criteria reflect the regional influences of natural variations in geology, land cover, and climate that affect background concentrations of nutrients. Most of the selected catchments in this study were in one of two nutrient ecoregions, the Nutrient-Poor Largely Glaciated Upper Midwest and Northeast (New York to Maine) and the Central and Eastern Forested Upland (New Jersey to Georgia). Catchment concentrations of total nitrogen and total phosphorus from headwater streams along the Appalachian Trail were compared to USEPA nutrient ecoregion criteria (table 11). Approximately 63.4 percent of catchment concentrations of total nitrogen in the Nutrient-Poor Largely Glaciated Upper Midwest and Northeast nutrient ecoregion were greater than the recommended USEPA nutrient criterion (table 11). Approximately 70.5 percent of the catchment concentrations of total phosphorus in the Central and Eastern Forested Upland nutrient ecoregion were greater than the recommended USEPA nutrient criterion (table 11).
Sections of the Appalachian Trail pass through urban areas and are adjacent to agricultural land (table 5). Intermittent influences from the regions of the Appalachian Trail where the percentages of developed or agricultural land are moderate may be increasing the number of catchments that have concentrations of total nitrogen and total phosphorus greater than the USEPA's nutrient ecoregion criteria. Dubrovsky and others (2010) compared simulated modeled estimations of background concentrations from Smith and others (2003) to the 14 USEPA nutrient ecoregion criteria. This comparison demonstrated that, for the Nutrient-Poor Largely Glaciated Upper Midwest and Northeast and the Central and Eastern Forested Upland nutrient ecoregions, the criteria would be difficult to meet even with only a small percentage of development. Overall concentration of total nitrogen and total phosphorus within the study area are lower than estimated national background concentrations but generally similar or higher than USEPA ecoregion nutrient criteria.

\section{Effects of Environmental Attributes on Water Quality}

Variations in water quality along the Appalachian Trail were evaluated with respect to selected environmental attributes to determine how natural or anthropogenic factors may be influencing the water quality of the headwater streams along and near the Appalachian Trail. Physical attributes such as elevation, slope, precipitation, and temperature were explored for correlation with water-quality constituents. Generalized major geologic units were used to group water-quality data along the Appalachian Trail to determine geologic effects

Table 11. Comparison, by nutrient ecoregion, of median catchment concentrations of total nitrogen and total phosphorus and the percentages of median catchment concentrations greater than U.S. Environmental Protection Agency's nutrient criteria from selected sampling sites along the Appalachian National Scenic Trail.

[mg/L, milligrams per liter]

\begin{tabular}{llcccc}
\hline Nutrient & \multicolumn{1}{c}{ Nutrient ecoregion } & $\begin{array}{c}\text { Nutrient } \\
\text { criterion } \\
(\mathbf{m g} / \mathbf{L})\end{array}$ & $\begin{array}{c}\text { Number of } \\
\text { catchments }\end{array}$ & $\begin{array}{c}\text { Median } \\
\text { catchment } \\
\text { concentrations } \\
\text { (mg/L) }\end{array}$ & $\begin{array}{c}\text { Percentages of median catch- } \\
\text { ment concentrations greater } \\
\text { than nutrient criterion }\end{array}$ \\
\hline Total nitrogen & $\begin{array}{c}\text { Nutrient-poor largely glaciated Upper } \\
\text { Midwest and Northeast }\end{array}$ & 0.38 & 71 & 0.42 & 63.4 \\
& Central and Eastern forested upland & 0.31 & 80 & 0.28 & 45.0 \\
\hline Total phosphorus & $\begin{array}{c}\text { Nutrient-poor largely glaciated Upper } \\
\text { Midwest and Northeast }\end{array}$ & 0.01 & 82 & 0.01 & 51.4 \\
& $\quad$ & & & \\
& Central and Eastern forested upland & 0.01 & 95 & 0.02 & 70.5 \\
\hline
\end{tabular}


on water quality. Anthropogenic factors such as developed and agricultural land use in the drainage area of headwater streams and atmospheric deposition of sulfate and nitrate in the catchments of headwater streams were evaluated with respect to possible influence on water quality.

\section{Elevation}

Catchment $\mathrm{pH}, \mathrm{ANC}$, and concentrations of major ions were significantly correlated with elevation along the length of the entire Appalachian Trail (table 12) except in the Lower New England ecosection where $\mathrm{pH}$ and most concentrations of major ions were not correlated with elevation. As elevation increases, $\mathrm{pH}, \mathrm{ANC}$, and concentrations of major ions decrease. Likewise, most concentrations of nutrients also were negatively correlated with elevation, although rho values were substantially lower than those computed for $\mathrm{pH}, \mathrm{ANC}$, and concentrations of major ions (table 12).

Elevation is not directly affecting streamwater chemistry but is more likely a proxy for the synergistic influences of environmental attributes that tend to be correlated with elevational gradients, such as geology, slope, drainage area, precipitation, temperature, and land cover (table 13). Generally, in the Eastern U.S. as elevation increases, drainage areas tend to become smaller and steeper, and geology at elevation tends to be increasingly resistant to weathering. The low residence times of small steep drainages coupled with relatively inert geology yield comparatively more dilute waters compared to surface waters at lower elevations. These types of high elevation landforms typically have little to no agricultural or developed land uses, and receive higher amounts of precipitation in cooler climates which also help to explain the inverse relation between water quality and elevation. The inverse correlation between elevation and streamwater chemistry also has been documented in local and regional investigations of areas along the Appalachian Trail (Cook and others, 1994; Shubzda and others, 1995; Hornbeck and others, 2001; Rice and others, 2005; Likens and Buso, 2006; Sullivan and others, 2007; Robinson and others, 2008). The variation of temperature with latitude along the Appalachian Trail is likely reducing the strength of the relation typically found between elevation and temperature at smaller scales (table 13). Mean annual temperature was negatively correlated with elevation at the ecosection scale.

\section{Geology}

Generalized major geologic units from Reed and Bush (2005) were used to group and evaluate differences in water quality. This geologic map was compiled to be used for national or regional assessments of geology and shows the age, distribution, and general character of the rocks (Reed and Bush, 2005). Ten major geologic units underlie the selected catchments and include rocks classified as sedimentary, gneissic, granitic, and volcanic (fig. 15). Most (over
78 percent) of the study area is underlain by sedimentary rocks. Sedimentary rocks classified by Reed and Bush include rocks that have been metamorphosed to varying extents but still retain evidence of their depositional age and origin (Reed and Bush, 2005). The regions of metamorphism are shown by a pattern in figure 15 . Approximately 13 percent of the study area is underlain by gneissic rocks, approximately 5 percent is underlain by granitic rocks, and 1.4 percent is underlain by volcanic rocks.

Table 12. Rho values from Spearman correlations of the elevations of catchments and the percentages of developed and agricultural land cover with concentrations of selected water-quality constituents in catchments that contained selected sampling sites along the Appalachian National Scenic Trail.

[All rho values are significant ( $p$ less than 0.05) from Spearman correlations]

\begin{tabular}{|c|c|c|c|}
\hline \multirow{2}{*}{$\begin{array}{l}\text { Water-quality parameter } \\
\text { or constituent }\end{array}$} & \multirow{2}{*}{ Elevation } & \multicolumn{2}{|c|}{ Percentages of land cover } \\
\hline & & Developed & Agricultural \\
\hline $\mathrm{pH}$ & -0.422 & 0.416 & 0.517 \\
\hline Acid neutralizing capacity & -0.613 & 0.557 & 0.557 \\
\hline Calcium & -0.564 & 0.522 & 0.455 \\
\hline Magnesium & -0.675 & 0.576 & 0.603 \\
\hline Sodium & -0.563 & 0.471 & 0.408 \\
\hline Sulfate & -0.687 & 0.579 & 0.451 \\
\hline Chloride & -0.691 & 0.555 & 0.565 \\
\hline Nitrate & -0.110 & 0.307 & 0.266 \\
\hline Total nitrogen & -0.312 & 0.423 & 0.241 \\
\hline Total phosphorus & -0.286 & 0.173 & 0.305 \\
\hline
\end{tabular}

Table 13. Rho values from Spearman correlations of elevation with selected environmental attributes of catchments that contain selected sampling sites along the Appalachian National Scenic Trail.

[Boldface indicates significant rho values ( $p$ less than 0.05) from Spearman correlations]

\begin{tabular}{lc}
\hline \multicolumn{1}{c}{ Environmental attributes } & Elevation \\
\hline Slope & $\mathbf{0 . 5 9 2}$ \\
Mean annual precipitation & $\mathbf{0 . 5 4 2}$ \\
Mean annual temperature & 0.046 \\
Percentage of developed land cover & $\mathbf{- 0 . 5 9 9}$ \\
Percentage of agricultural land cover & $\mathbf{- 0 . 5 6 8}$ \\
\hline
\end{tabular}




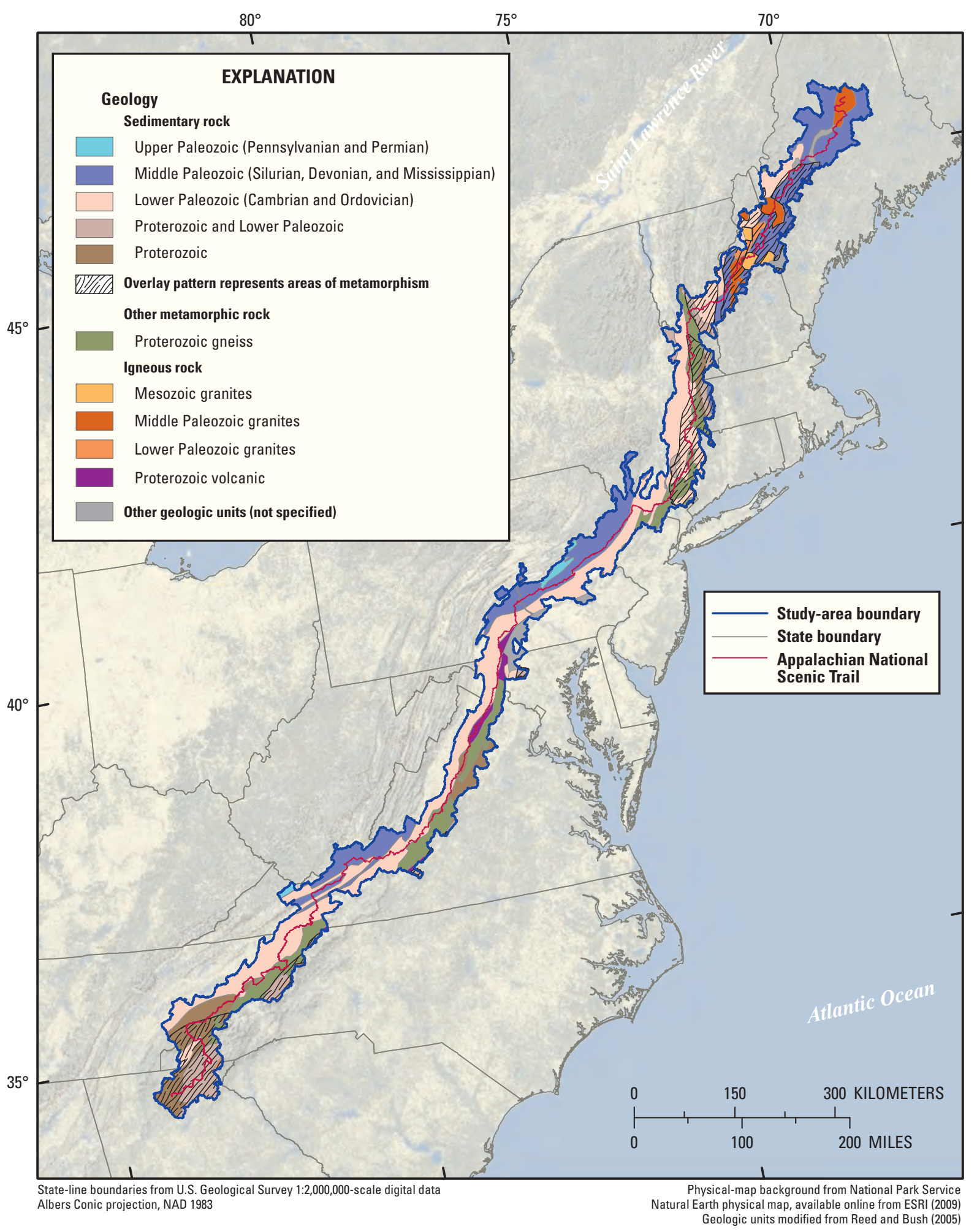

Figure 15. Major geologic units within the study area. Major geologic units that did not underlie catchments from the selected first- and second-order streams within the study are grey. 
For evaluation of geology with respect to water quality, the major geologic units were combined into six rock types (sedimentary rocks, metasedimentary rocks, metasedimentary rocks that contain carbonate minerals, gneissic rocks, granitic rocks, and volcanic rocks). The six rock types used in analysis were created by aggregating similar rocks from different geologic ages. For example, the sedimentary rock group included the Late Proterozoic sedimentary rocks, Late Proterozoic and Lower Paleozoic sedimentary rocks, Lower Paleozoic (Cambrian and Ordovician) sedimentary rocks, Middle Paleozoic (Silurian, Devonian, and Mississippian) sedimentary rocks, and the Upper Paleozoic (Pennsylvanian and Permian) sedimentary rocks. The sedimentary group was then subdivided to reflect whether a catchment was in a region of metamorphism and whether the rocks were classified as containing carbonate minerals (King and Beikman, 1974) because these geologic attributes can have a strong influence on the water quality. Granitic major geologic units that were combined into the granitic group included the Lower Paleozoic, Middle Paleozoic, and the Mesozoic granitic rocks. Only one major geologic unit each was adequate for gneissic rocks (Middle Proterozoic gneiss) and volcanic rocks (Late Proterzoic volcanic rocks).

Catchment values of $\mathrm{pH}$, specific conductance, and ANC were compared among the six geologic groups (fig. 16). Generally, sedimentary rocks and metasedimentary rocks had similar median catchment values for $\mathrm{pH}$, specific conductance, and ANC (fig. 16). For the sedimentary rocks, the median $\mathrm{pH}$ was equal to 6.6 , specific conductance was equal to 23.7 , and $\mathrm{ANC}$ was equal to $88.7 \mu \mathrm{eq} / \mathrm{L}$. Similarly, catchments in the metasedimentary rocks had a median $\mathrm{pH}$ of 6.5 , median specific conductance of 20.3 , and median ANC of $86.3 \mu \mathrm{eq} / \mathrm{L}$. However, catchment values for $\mathrm{pH}$ and ANC were statistically higher in the metasedimentary rocks that were classified as containing carbonate minerals compared to the other two groups of sedimentary rocks (median $\mathrm{pH}$ of 7.3 ; median ANC value of $590 \mu \mathrm{eq} / \mathrm{L}$ ). The median catchment values of $\mathrm{pH}$ in the gneissic and volcanic rocks were statistically similar to that of the metasedimentary rocks that contain carbonate minerals (6.8 and 7.1, respectively) (fig. 16). Additionally, the catchment values of ANC in the volcanic rocks were among the highest with a median value of $220 \mu \mathrm{eq} / \mathrm{L}$ (fig. 16). Catchment $\mathrm{pH}$ and $\mathrm{ANC}$ values from granitic rocks were the lowest compared to the other rock types (median $\mathrm{pH}$ value of 6.0; median ANC value of $57 \mu \mathrm{eq} / \mathrm{L}$ ) (fig. 16).

The presence of carbonate minerals appears to be the more influential geologic attribute with respect to $\mathrm{pH}$, specific conductance, and ANC in the headwaters along the Appalachian Trail. Catchments were classified as containing carbonate minerals through the use of a national geologic map by King and Beikman (1974), who compiled national geologic data at a finer scale than Reed and Bush (2005) $(1: 2,500,000$ and $1: 7,500,000$ scales, respectively) and characterized discrete areas of the sedimentary rocks in the region of the Green-Taconic-Berkshire Mountains, Lower New England, and Hudson Valley ecosections as containing carbonate minerals. This may provide a geologic explanation for generally higher $\mathrm{pH}$, specific conductance, ANC, concentrations of cations, and concentration of anions that are observed in these three ecosections relative to other ecosections (figs. 14A-J).

In general, the coarse scale of the geologic data could not be related to the fine-scale spatial variations in water quality such as variations within ecosections. Sullivan and others (2007), however, produced a lithologic map (at a scale of approximately 1:500,000) based on aggregated geologic map units for the southern Appalachian Mountains and were able to identify lithologies that were more likely to be associated with low-ANC surface water. Sullivan and others (2007) demonstrated that streams in the southern Appalachian Mountains in or downgradient from drainage areas that are predominantly underlain by siliceous lithologies have a greater probability of low ANC. These findings are consistent with other studies that were conducted in and around the Shenandoah National Park in Virginia (Bricker and Rice, 1989; Rice and others, 2005). In addition, these findings demonstrate that, with relatively highresolution geologic information, significant relations can be determined between water quality and the underlying lithology at relatively fine scales.

\section{Land Cover}

The percentages of developed or agricultural land cover in the drainage areas of catchments selected for this inventory were generally low, although sections of the Appalachian Trail do pass through or near major urban areas or agricultural land (table 5). Along the entire Appalachian Trail, the percentages of developed and agricultural land were significantly and positively correlated with $\mathrm{pH}, \mathrm{ANC}$, concentrations of major ions, and concentrations of nitrate, total nitrogen, and total phosphorus (table 12). Within ecosections, these correlations were less significant. Insufficient spatial representation of a gradient of developed or agricultural land uses within ecosections may explain why these correlations were significant at the whole study-area scale of Appalachian Trail and not within ecosections. Many studies have demonstrated that land use influences stream quality. Siemion and Murdoch (2010) and Hickman and Fischer (2007) both reported that ANC and concentrations of most major ions and nutrients were positively correlated with agricultural land cover in the Delaware Water Gap National Recreation Area. The percentages of agricultural land cover in these two studies were generally higher than for the selected sampling sites in this project. (figs. 14B-J, table 8).

\section{Atmospheric Deposition}

Previous studies of areas near the Appalachian Trail have demonstrated the negative effects of atmospheric deposition on water quality. Atmospheric-deposition data were compared to water-quality data to determine relations between these two datasets. The NADP publishes annual maps of 


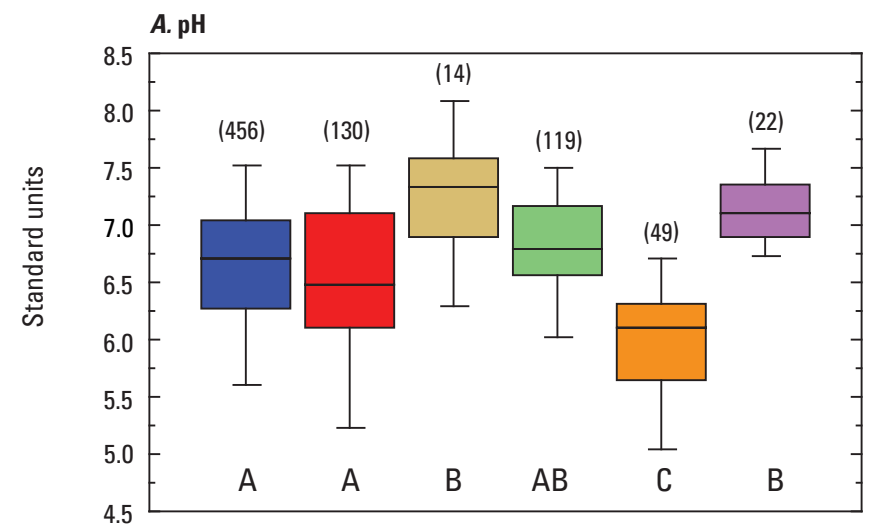

\section{EXPLANATON}
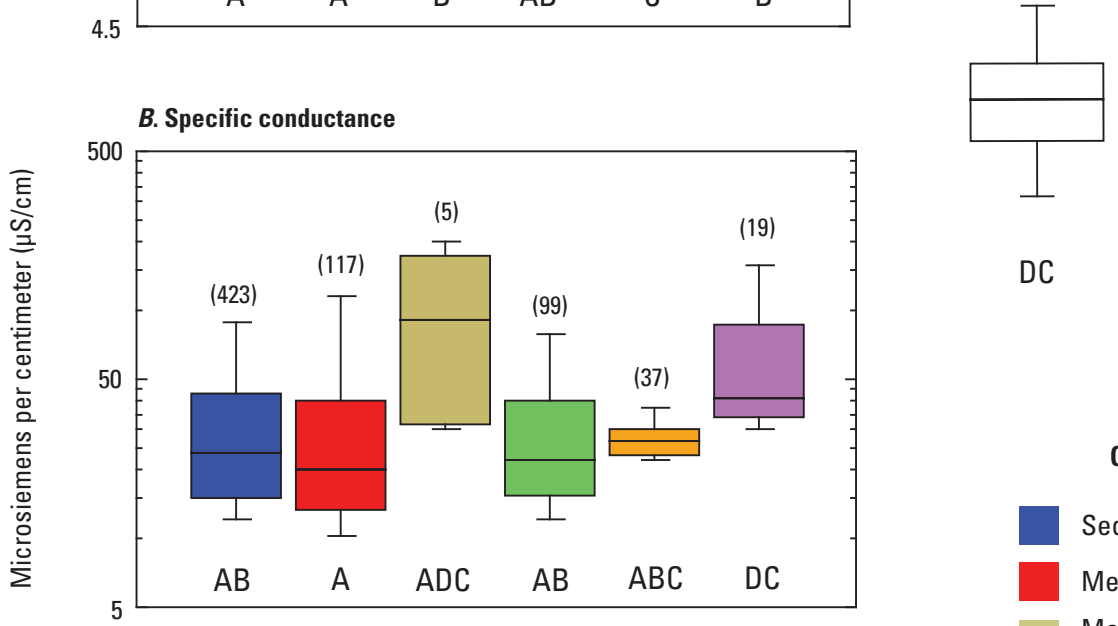

Boxplots

(22) Number of catchments

90th percentile

75th percentile

50th percentile (median)

25th percentile

10th percentile

DC Statistical group from nonparametric Tukey's multiple-comparison test (groups with the same letter are not significantly different)

Geologic groups

Sedimentary rocks

Metasedimentary rocks

Metasedimentary rocks that contain carbonate minerals

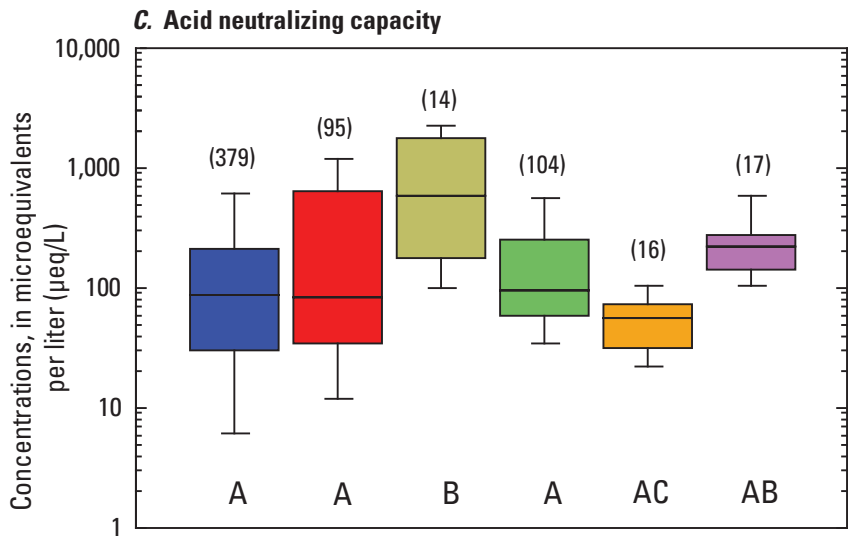

Gneissic rocks

Granitic rocks

Volc anic rocks

Figure 16. Comparison of concentrations, by major geologic groups, of $A, \mathrm{pH}, B$, specific conductance, and $C$, acid neutralizing capacity from catchments that contained selected first- and second-order streams along the Appalachian National Scenic Trail. 
precipitation-weighted mean concentrations of sulfate and nitrate in precipitation. The values are interpolated from measurements at specific sites (National Atmospheric Deposition Program, 1994a, b). Since most of the sulfate and nitrate data used in this project were collected in the mid-1990s, atmospheric sulfate and nitrate data from the NADP for 1994 were selected for comparison purposes. Atmospheric-deposition rates of sulfate and nitrate were computed by combining the NADP atmospheric-concentration data with high-resolution spatial estimates of precipitation rates for the same year (Latysh and Wetherbee, in press; PRISM Climatic Group, 2006b). The resulting maps of sulfate and nitrate atmospheric deposition (in kilograms per hectare) are shown in figure 17. Mapped values were assigned to catchments in the study area, which enabled the comparison of atmospheric-deposition rates with other catchment attributes and with water-quality data. Atmospheric deposition was estimated by ecosection, including all first- and second-order catchments in the study area and not just the catchments with selected sampling sites.

\section{A. Sulfate}

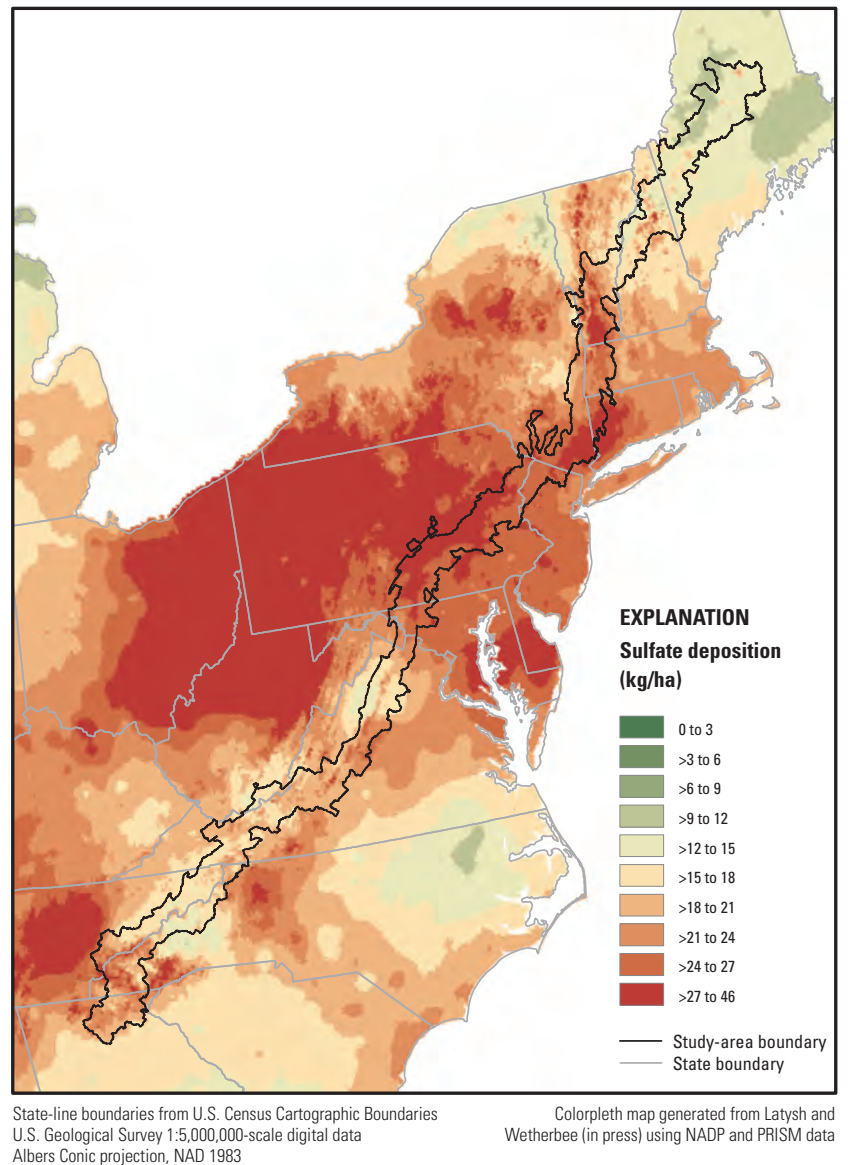

Along the Appalachian Trail, atmospheric deposition is estimated to be high (greater than $20 \mathrm{~kg} / \mathrm{ha}$ ) at both the highest and lowest elevations. The spatially sustained estimates of high deposition (figs. 17 and 18) were broadest in the central portion of the Appalachian Trail, whereas estimates were highest for the highest elevations in the northern and southern sections of the Appalachian Trail. The Green-Taconic-Berkshire Mountains, Lower New England, Hudson Valley, Northern Glaciated Allegheny Plateau, and Northern Ridge and Valley ecosections have median deposition estimates greater than $24 \mathrm{~kg} / \mathrm{ha}$ for sulfate and greater than $19 \mathrm{~kg} / \mathrm{ha}$ for nitrate (figs. 18A-B). In the southern region of the Appalachian Trail (Allegheny Mountains and Blue Ridge Mountains ecosections), Great Smoky Mountains National Park has historically received high estimates of deposition. The Integrated Forest Study, which monitored forested sites across the U.S., Canada, and Norway to investigate the effects of acidic deposition on nutrient cycling in forest ecosystems, reported that the Noland Divide Watershed in the Great Smoky Mountains

\section{B. Nitrate}

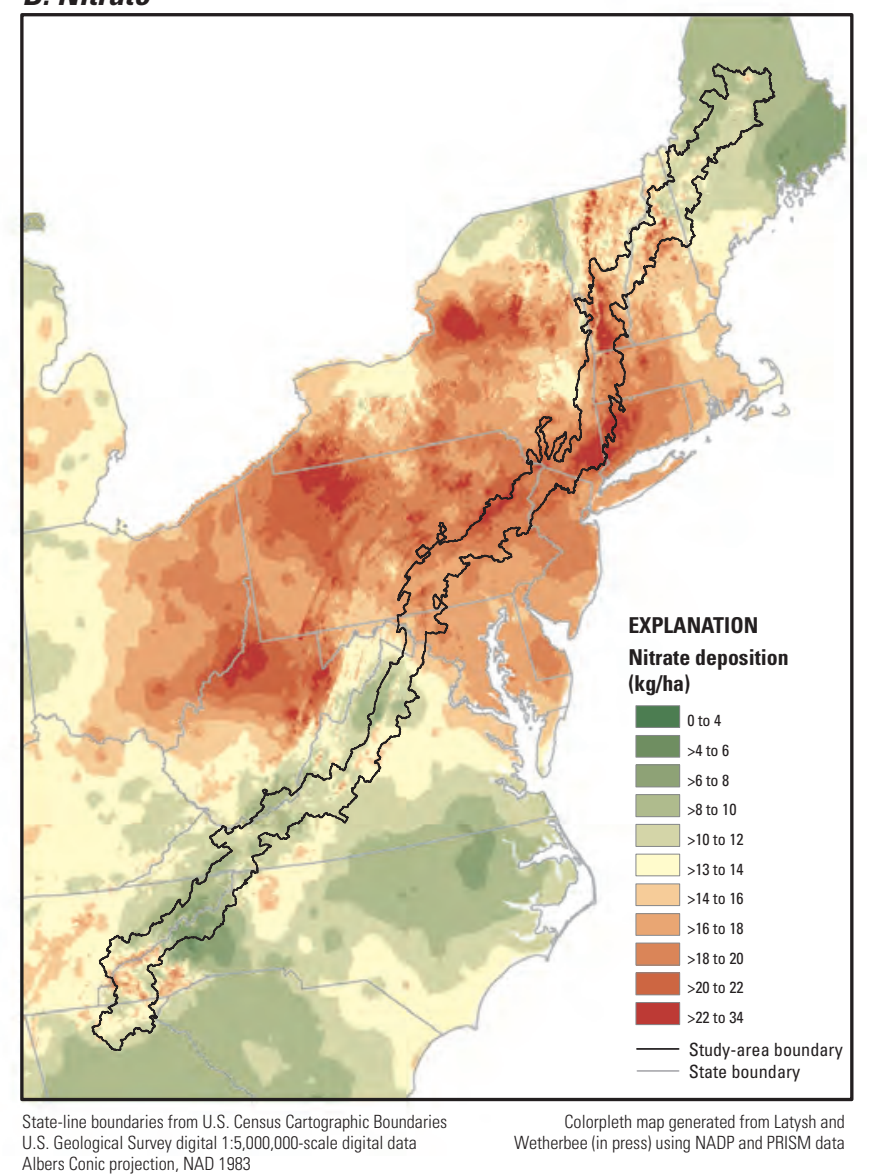

Figure 17. Maps of 1994 annual wet-deposition estimates for $A$, sulfate and $B$, nitrate for the eastern United States, including the study area. Deposition values were computed using methods from Laytsh and Wetherbee (in press) with atmospheric concentration data from the National Atmospheric Deposition Program National Trends Network (National Atmospheric Deposition Program, 1994 a, b) and precipitation from the PRISM climate group (PRISM Climate Group, 2006b). 

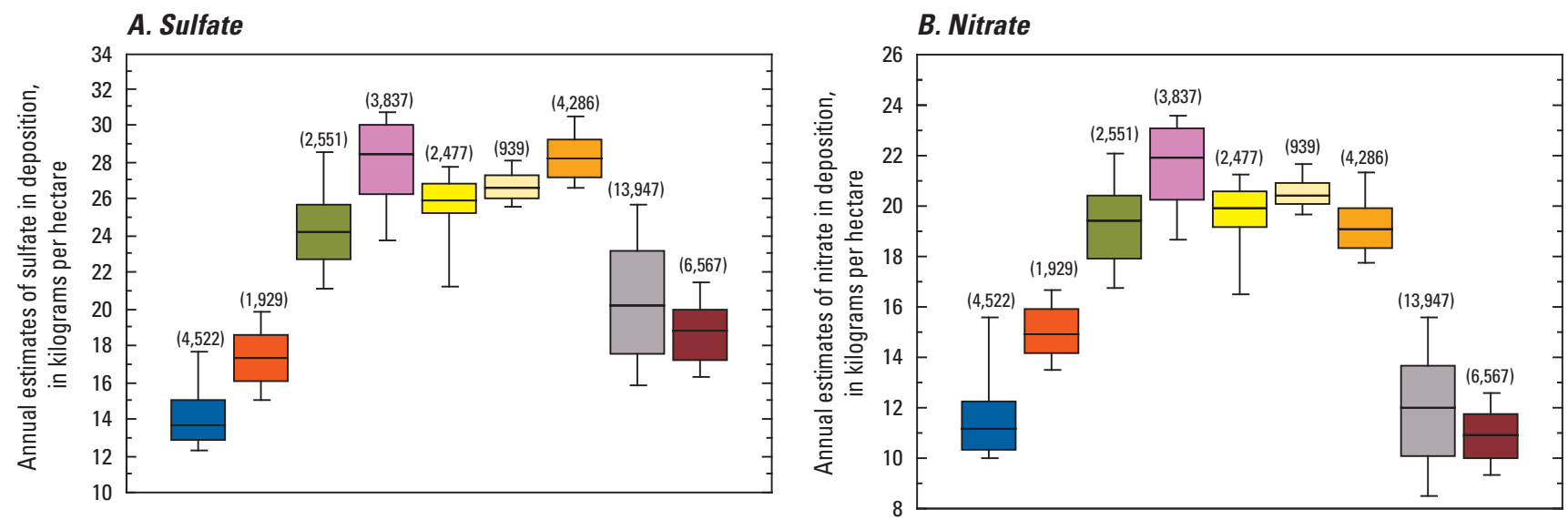

\section{EXPLANATION}

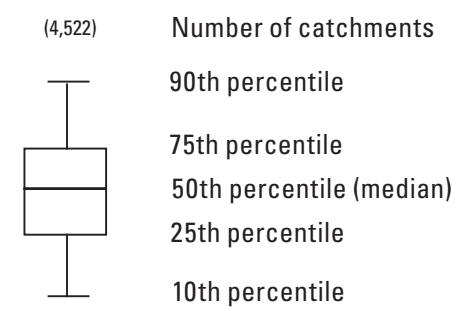

White Mountains

Vermont-New Hampshire Upland

Green-Taconic-Berkshire Mountains

Lower New England

Hudson Valley
Northern Glaciated Allegheny Plateau

Northern Ridge and Valley

Blue Ridge Mountains

Allegheny Mountains

Figure 18. Wet-deposition estimates from 1994 of $A$, sulfate and $B$, nitrate by U.S. Forest Service ecological sections (ecosections) for all first and second order catchments in the study area. Deposition values were computed using methods from Laytsh and Wetherbee (in press) with atmospheric concentration data from the National Atmospheric Deposition Program National Trends Network (National Atmospheric Deposition Program, 1994a, b) and precipitation data are from the PRISM climate group (PRISM Climate Group, 2006b). Ecosections are shown left to right in approximate north-to-south order.

National Park received the highest sulfate and nitrate deposition compared to the other Integrated Forest Study sampling sites (Shubzda and others, 1995). Generally higher elevations are more likely to receive high depositions, however for the five ecosections in the central region of the Appalachian Trail, climatic patterns and possibly sources of sulfate and nitrate, to some extent, outweigh the elevation-induced effects of precipitation on estimates of atmospheric deposition.

Catchment concentrations of sulfate in streamwater were statistically greater in the ecosections that received the highest atmospheric deposition estimates of sulfate (figs. 14H and 18A). However, catchment concentrations of nitrate and total nitrogen in streamwater were not statistically greater in the ecosections that receive the highest atmospheric deposition of nitrate (figs. 14J and L).

Previous studies have demonstrated a link between high concentrations of sulfate in precipitation and sulfate typically being the dominant anion in low-ionic strength waters (Charles and Christie, 1991; Likens and Bormann, 1995; Driscoll and others, 1998; Elliott and others, 2008). Sulfate was most frequently determined to be the predominant anion in waters in the Appalachian Trail study area except in the Lower New England and Hudson Valley ecosections, where bicarbonate was the most frequently calculated predominant anion. Although the central region of the Appalachian Trail received higher amounts of sulfate deposition, the areas along the Appalachian Trail with waters of lower ionic strength (White Mountains, Allegheny Mountains, Blue Ridge Mountains ecosections) might have been more strongly affected by sulfate deposition.

Reductions in concentrations of sulfate and nitrate in atmospheric deposition related to the CAAA have been observed throughout the Midwest and Eastern United States, specifically in the central Appalachians (U.S. Environmental Protection Agency, 2010) that includes the Green-TaconicBerkshire Mountains, Lower New England, Hudson Valley, Northern Glaciated Allegheny Plateau, and Northern Ridge and Valley ecosections. Reductions in sulfate have been more significant than reductions in nitrogen - approximately 40 and 20 percent, respectively (U.S. Environmental Protection Agency, 2010). The estimates of atmospheric deposition by ecosection shown in figures 17 and 18 were a reasonable fit for the data compiled for this inventory but may not represent a current estimate (2011) of concentrations in atmospheric deposition. 
Trends in concentrations of sulfate and nitrate in streams along the Appalachian Trail were not assessed. Regional investigations that have been completed near the Appalachian Trail reported that concentrations of sulfate and nitrate in surface water are decreasing in response to changes in atmospheric deposition (Driscoll and others, 1998; Driscoll and others, 2003; Stoddard and others, 2003; Kahl and others, 2004; Webb and others, 2004; Monteith and others, 2007). The degree of response is likely to vary along the Appalachian Trail; however, surface waters with the lowest ANC and lowest $\mathrm{pH}$ were reported to have shown the largest and most rapid response (Stoddard and others, 2003; Kahl and others, 2004). In the eastern U.S., three processes have been identified that complicate the assessment of surface-water response to decreases in atmospheric deposition: increasing concentrations of chloride from road-salting practices that alter the acid-base chemistry of a watershed, increasing concentrations of dissolved organic carbon, and the retention of sulfate in watershed soils in nonglaciated areas (Rochelle and Church, 1987; Stoddard and others, 2003; Kahl and others, 2004; Webb and others, 2004; Monteith and others, 2007; Rosfjord and others, 2007). These processes will likely play varying roles in assessments of trends in concentrations of sulfate and nitrate in headwater streams along the Appalachian Trail.

The more chemically dilute surface waters in the northern and southern regions of the Appalachian Trail than in the central region of the Appalachian Trail may be attributed to differences in most of the environmental attributes explored (elevation, geology, land use, and deposition). The central region of the Appalachian Trail (including the Lower New England, Hudson Valley, Northern Glaciated Allegheny Plateau, Northern Ridge and Valley, and to a lesser extent the Vermont-New Hampshire Upland and Green-TaconicBerkshire Mountains ecosections) generally had the highest catchment values of $\mathrm{pH}, \mathrm{ANC}$, and concentrations of major ions. In addition, the catchments in these ecosections also were the lowest in elevation and contained the highest percentages of developed and agricultural land cover. These three environmental attributes were demonstrated to be positively correlated with catchment $\mathrm{pH}, \mathrm{ANC}$, and concentrations of major ions. Portions of ecosections in the central region of the Appalachian Trail were associated with carbonate geologic units. The presence of carbonate minerals in the geology underlying a catchment could have substantial influence on $\mathrm{pH}, \mathrm{ANC}$, and major-ion chemistry. The central region of the Appalachian Trail also was shown to receive the highest estimated concentrations of sulfate and nitrate in atmospheric deposition. It is difficult to discern on the basis of the data compiled for this project whether the type of land cover, the lithology of the underlying geology, inputs of atmospheric deposition, or a combination of these factors is responsible for the distinctly different water quality in the central region of the Appalachian Trail compared to the northern and southern regions of the Appalachian Trail.

\section{Implications of Using Available Data and Considerations for Future Monitoring}

The compilation of available water-quality data for this study was useful in identifying regions along the Appalachian Trail where water-quality data are lacking spatially and temporally. As was previously described, there is a notable lack of sampling sites that met this projects criteria in the state of Maine. The spatial density of available sampling sites along the border between Tennessee and North Carolina and north of Great Smoky Mountains National Park also was low, though not as low as in Maine. The spatial gaps were more profound when the data density for specific water-quality constituents was evaluated.

In the 831 catchments where water-quality data was collected, field properties such as $\mathrm{pH}$, specific conductance, temperature, and dissolved oxygen were the most commonly measured parameters. The next most frequently measured type of water-quality data was concentrations of major ions, including, calcium, chloride, magnesium, potassium, sodium, and sulfate. Of the four nutrients of interest, nitrate had the largest number of data values; however, very little nitrate data were available from areas along the Appalachian Trail north of Massachusetts. Ammonia was the most widely collected nutrient, followed by total phosphorus. Spatial coverage of total nitrogen data for the White Mountains of New Hampshire, the southern part of Pennsylvania, and the western mountains of Virginia were moderately good, but lacking for other regions of the Appalachian Trail.

It is important to note a temporal-limitation of the data compiled for this inventory to represent current (2011) waterquality conditions along the Appalachian Trail. Specifically, spatial comparisons of concentrations of sulfate and nitrate may be biased because concentrations of sulfate and nitrate in streamwater have been reported to be declining in response to reductions in deposition related to the CAAA. Much of the data in the northern section region were from the 1980s and would be more representative of water quality influenced by deposition loads of that decade. Whereas, the collection dates of water-quality samples from the southern section (median year $=1997$ ) reflect the inclusion of TIME/LTM stream sites, VTSSS sites, and Great Smoky Mountains National Park sites, at which water-quality data are being actively collected (2011). The comparatively lower concentrations of sulfate and nitrate in streamwater in the Blue Ridge Mountains and Allegheny Mountains ecosections may reflect the inclusion of more recent (post-2000) data that has responded to decreases in atmospheric deposition.

Water-quality data were not evaluated within the context of hydrologic condition because of the lack of streamflow measurements available for many sites. Future monitoring programs for water quality along the Appalachian Trail should consider locating sampling sites within gaged watersheds, so 
that water-quality data can be related to streamflow. Assessments of trends in the water quality of streams over time are frequently done through a comparison of changes in loads or flow-adjusted concentrations. The calculation of load for a given parameter is dependent on both the concentration and streamflow at the time of sample collection. The calculation of relations between streamflow and water quality for streams along the Appalachian Trail would provide a useful tool to evaluate water-quality trends in this environment. Generally, streamgages are placed in larger watersheds; however, the Hubbard Brook and Coweeta LTER areas represent good examples of small watersheds that have generated useful timeseries chemical and hydrological data.

The data compiled for this inventory were generally either from the largest national databases of water-quality data (NWIS and STORET), federal agencies (for example, USEPA Wadeable Streams Assessment and National Stream Survey), or from well established programs (i.e. National Science Foundation LTER and the VTSSS). The inclusion of new water quality data in selected catchments and in catchments where data were not compiled for this inventory would improve the spatial and temporal resolution of available data from which to assess water resources. Continued integration of more recent data from the data sources used would be an efficient future effort in making the Appalachian Trail inventory of water-quality data more relevant for continued evaluation of basic water quality and in trend analysis. In addition, an effort to obtain and compile water-quality data from local citizen-based water-quality monitoring programs may be beneficial and facilitate a connection between local and regional scale water-quality issues. These smaller programs are typically initiated and focused on the intention of using scientific information to help locally preserve natural resources; this objective is common with aspects of the NPS mission. Collaborative arrangements to centralize waterquality data among agencies, programs, and researchers interested in the water resources of the Appalachian Trail region may serve to maintain the relevancy of the data compiled for this inventory.

\section{Summary}

An inventory of water-quality data was conducted to provide an assessment of water quality in headwater (firstand second-order) streams along the Appalachian National Scenic Trail (Appalachian Trail). The Appalachian Trail is a cooperatively managed National Park along the Appalachian Mountains from Maine to Georgia. Available data on basic chemical quality were compiled from 14 different agencies or projects including the U.S. Geological Survey (USGS); the U.S. Environmental Protection Agency (USEPA); the National Park Service; the United States Forest Service; (USFS); the National Science Foundation, including the Long-Term Ecological Research Program; the Water Resources Research
Center at the University of Massachusetts, Amherst; and the Department of Environmental Sciences at the University of Virginia. To maximize the amount of water-quality data available for use in this inventory and to provide a more robust assessment of the water quality of headwater streams along the Appalachian Trail, a method of sampling-site selection was developed based on proximity, hydrologic boundaries, and environmental settings. Hydrologic boundaries were used to define the watersheds draining the Appalachian Trail, and NHDPlus digital hydrologic data were used to define the catchment as the fundamental areal unit for location information for sampling sites.

The approach used for site selection in this study quantified selected physical attributes of catchments adjacent to the Appalachian Trail to build a criteria matrix by which sampling sites not adjacent to the Appalachian Trail could be compared and evaluated for inclusion. Stream elevation and the percentages of developed and agricultural land cover in the drainage areas of adjacent catchments were used to build the criteria. There were 1,817 sampling sites selected for water-quality characterization. These selected sites were either adjacent to the Appalachian Trail or in landscapes that are locally high in elevation and generally had little to no developed or agricultural land cover in the drainage area.

Water-quality data from sampling sites were aggregated by catchments to reduce the spatial bias of intensively sampled sites and regions and at least one median water-quality value was computed for each of 831 catchments. The number of catchments for which a median value was calculated varies by water-quality parameter. Field properties were the most commonly measured, followed by concentrations of major ions and nutrients. Catchment concentrations of selected water-quality constituents were summarized overall and by USFS ecological sections (termed ecosections in this study). The $\mathrm{pH}$ of headwater streams from the Appalachian Trail study ranged from 4.0 to 8.9 with a median value of 6.7. Specific conductance values ranged from 4.0 to 761 microsiemens per centimeter $(\mu \mathrm{S} / \mathrm{cm})$, with a median value of $23.8 \mu \mathrm{S} / \mathrm{cm}$. Acid neutralizing capacity (ANC) ranged from -11.3 to 4,400 microequivalents per liter $(\mu \mathrm{eq} / \mathrm{L})$ with a median value of $98.7 \mu \mathrm{eq} / \mathrm{L}$. Catchment concentrations of cations (calcium, magnesium, sodium, and potassium) were low with the median catchment concentration for each of the cations being less than 1.5 milligrams per liter $(\mathrm{mg} / \mathrm{L})$. Calcium had the highest median catchment concentration of all the cations $(1.46 \mathrm{mg} / \mathrm{L})$. Catchment concentrations of anions (sulfate, chloride, and nitrate) ranged more widely than those of cations. Sulfate had the highest median catchment concentration $(3.41 \mathrm{mg} / \mathrm{L})$, followed by chloride $(0.78 \mathrm{mg} / \mathrm{L})$. Analysis to characterize water types demonstrated that, for most regions of the Appalachian Trail, no specific cation was predominant. The Lower New England and Hudson Valley ecosections were the exceptions, where the predominant cation in most catchments was calcium. Sulfate was the most frequently detected anion except in the Lower New England and Hudson Valley ecosections where the predominant anion 
was bicarbonate. Similar to major ions, nutrient concentrations also were low (median catchment concentrations of total nitrogen and nitrate species were less than $0.4 \mathrm{mg} / \mathrm{L}$, and the median catchment concentration of total phosphorus were less than $0.02 \mathrm{mg} / \mathrm{L}$ ).

Distinct spatial variations in $\mathrm{pH}, \mathrm{ANC}$, and major-ion chemistry were apparent along the length of the Appalachian Trail. The northern and southern regions of the Appalachian Trail (including the White Mountains, Blue Ridge Mountains, and Allegheny Mountains ecosections) had the lowest catchment $\mathrm{pH}$ values. The White Mountains ecosection was statistically unique and had the lowest median catchment $\mathrm{pH}$ value of all the ecosections (median catchment $\mathrm{pH}=6.1$ ). Catchment ANC and concentrations of most major ions also were statistically lower in the White Mountains, Blue Ridge Mountains, and Allegheny Mountains ecosections compared to the other ecosections.

The ANC of waters from the White Mountains, Blue Ridge Mountains, and Allegheny Mountains ecosections were exceptionally low and included negative values. The White Mountains, Allegheny Mountains, and Blue Ridge Mountains ecosections contained the highest percentage of catchments that were classified as either acidic or sensitive. Low ANC waters are sensitive to seasonal or event-driven episodic acidification. When episodic acidification occurs in a stream, streamwater quality may become harmful to aquatic life.

Catchment concentrations of ammonia, nitrate, total nitrogen, and total phosphorus from selected headwater streams along the Appalachian Trail were generally lower than national estimated background concentrations determined by the USGS for surface waters. The Green-Taconic-Berkshire Mountains and the Northern Ridge and Valley ecosections were the exceptions. These ecosections had median catchment concentrations of ammonia more than two times greater than the estimated background concentrations. The Northern Ridge and Valley ecosection had median catchment concentrations of nitrate greater than the estimated national background concentrations ( 0.416 and $0.24 \mathrm{mg} / \mathrm{L}$, respectively).

Median catchment concentrations of total nitrogen and total phosphorus were compared to USEPA's ecoregion nutrient criteria. Median concentrations of total nitrogen in approximately 63 percent of catchments in the Nutrient Poor Largely Glaciated Upper Midwest and Northeast were higher than the USEPA regional criterion. Approximately 71 percent of median concentrations of total phosphorus in the Central and Eastern Forested Upland nutrient ecoregion were higher than the USEPA regional criterion. Findings from Dubrovsky and others (2010) suggest that the USEPA criteria in some nutrient ecoregions may be difficult to meet with modest amounts of development or agriculture in the drainage area. Sections of the central region of the Appalachian Trail are adjacent to areas of development and agricultural land. These nonforested land cover types may be contributing to the percentages of catchments that have total nitrogen and total phosphorus concentrations greater than USEPA nutrient criteria.
Spatial variations in water-quality properties of surface waters along the Appalachian Trail were related to elevation, geology, land cover, and atmospheric deposition. Median $\mathrm{pH}$, specific conductance, ANC, and concentrations of major ions (calcium, magnesium, sodium, sulfate, chloride, nitrate, total nitrogen, and total phosphorus) were all negatively correlated with elevation along the Appalachian Trail. For the Lower New England, Hudson Valley, Northern Glaciated Allegheny Plateau, and Northern Ridge and Valley ecosections, nitrate also was negatively correlated with elevation. Elevation, as such, most likely does not directly affect stream-water chemistry but is more likely a surrogate that represents the combined effects of environmental attributes that are themselves correlated with elevation, including geology, slope, drainage area, precipitation, temperature, and land cover.

Approximately, 78 percent of the study area is underlain by sedimentary or metasedimetary rocks. Most of the remaining study area is underlain by gneissic, granitic, and volcanic rocks (13, 5, and 1.5 percent, respectively). Metasedimentary rocks were further subdivided to distinguish between metasedimentary rock and metasedimentary rocks that contain carbonate minerals. The presence of carbonate minerals appears to be the most influential geologic attribute with respect to $\mathrm{pH}$, specific conductance, and ANC values. Catchments that were classified as being underlain by metasedimentary rocks that contained carbonate minerals had the highest values for $\mathrm{pH}$, specific conductance, and ANC. The Green-TaconicBerkshire Mountains, Lower New England, and Hudson Valley ecosections, which contained the highest catchment $\mathrm{pH}$, $\mathrm{ANC}$, and concentrations of most major ions, are underlain, at least in some areas, by metasedimentary rocks that contain carbonate minerals. Catchment values of $\mathrm{pH}$ in the gneissic and volcanic rocks were statistically similar to the metasedimentary rocks with carbonate minerals, however, very little of the study area is underlain by these rock types. The granitic rocks occur primarily north of Vermont in the White Mountains ecosection. Catchments underlain by these granitic rocks contained among the lowest $\mathrm{pH}$, specific conductance and $\mathrm{ANC}$ values.

The percentages of developed urban or agricultural land cover in the drainage areas of catchments was significantly and positively correlated with catchment $\mathrm{pH}, \mathrm{ANC}$, and concentration of most major ions (calcium, magnesium, sodium, sulfate, chloride, and nitrate). Nutrients were significantly, although weakly, correlated with the two land-cover variables. The regions along the Appalachian Trail that contained high percentages of developed and agricultural land cover in the drainage area were also underlain by major geologic units that may contain carbonate rocks.

Atmospheric deposition of sulfate and nitrate as demonstrated by previous investigations may have lead to widespread deleterious effects on the water quality of headwater streams near the Appalachian Trail. Annual atmospheric deposition maps of sulfate and nitrate produced by the National Atmospheric Deposition Program and the USGS demonstrate that portions of the Appalachian Trail receive some of the 
highest concentrations of sulfate and nitrate in the eastern United States. The section of the Appalachian Trail that received the overall highest estimates of atmospheric deposition generally contained in the lowest elevations (GreenTaconic-Berkshire Mountains, Lower New England, Hudson Valley, Northern Glaciated Allegheny Plateau, and Northern Ridge and Valley ecosections). Generally, there were higher catchment concentrations of sulfate in the ecosections that received the highest inputs of atmospheric deposition (GreenTaconic-Berkshire Mountains, Lower New England, Hudson Valley, Northern Glaciated Allegheny Plateau, and Northern Ridge and Valley). However, these same ecosections also contained the highest concentrations of most major ions. Sulfate deposition in the ecosections that contain the waters of lowest ionic strength (White Mountains, Blue Ridge Mountains, and Allegheny Mountains ecosections) may have a more profound effect on the chemical character of the surface waters as shown by the predominance of the sulfate anion in surface waters in these ecosections.

In general, the surface waters of the Appalachian Trail environment are dilute in constituents. Although this finding was not unexpected, the low ionic strength of Appalachian Trail surface waters may affect management and preservation strategies. These data also demonstrate that the waters of the central region of the Appalachian Trail, although still dilute, had statistically higher concentrations of most major ions and ANC than the northern and southern sections. Furthermore, the central section of the Appalachian Trail contained some of the highest percentages of developed and agricultural land uses and received the highest estimates of sulfate and nitrate from atmospheric deposition. It is difficult to tell from these data whether the water quality in the central section of the Appalachian Trail has been influenced more by the higher percentages of developed or agricultural land cover, higher inputs of atmospheric deposition, or the lithology of the underlying geology.

Managing the water resources of the Appalachian Trail is a complex and challenging responsibility because the headwater streams are generally dilute and therefore sensitive to atmospheric deposition. As has been demonstrated by previous investigations of discrete sections of the Appalachian Trail and regions near the Appalachian Trail, the water resources of the Appalachian Trail have been altered by atmospheric deposition of sulfate and, to a lesser extent, nitrate. Furthermore, because of the intrinsic connection between headwaters and downstream areas, degradation of the headwaters along the Appalachian Trail most likely has affected the water quality of downstream resources. A specific set of sampling sites that are collocated with continuous flow record sites could be used to assess long-term trends in stream-water chemistry along the Appalachian Trail. The ability to assess and compare changes in streamflow-adjusted water-quality data would provide a clearer characterization of past and current water-quality conditions that would be helpful for resource managers in the management and protection of local catchments and water resources of the Appalachian Trail. The periodic inclusion of more recent data from data sources used in the Appalachian Trail water-quality inventory would be relatively straightforward and beneficial. Furthermore, an expanded effort to obtain data not compiled (such as water quality from localized citizen based monitoring programs) also would add value and maintain the relevancy of the effort of this inventory. A dynamic and timely database relevant to the Appalachian Trail study area water resources available to the NPS and to the consortium of researchers interested in understanding the impacts of climate change on water quality may facilitate more efficient collaboration to develop strategic ecological sound management practices based on scientific knowledge.

\section{Selected References}

Acid Rain Monitoring Project, 2008, Water Resource Institute of Massachusetts, Amherst, Massachusetts accessed on February 10, 2010, at http://www.umass.edu/tei/wrrc/arm/ index.html.

Alexander, R.B., Boyer, E.W., Smith, R.A., Schwarz, G.E., and Moore, R.B., 2007, The role of headwater streams in downstream water quality: Journal of the American Water Resources Association, v. 43, no. 1, p. 41-59.

Allen, J.D., 1995, Stream ecology structure and function of running waters: London, Chapman \& Hall, 388 p.

Baker, J.P., Van Sickle, J., Gagen, C.J., DeWalle, D.R., Sharpe, W.E., Carline, R.F., Baldigo, B.P., Murdoch, P.S., Bath, D.W., Kretser, W.A., Simonin, H.A., and Wigington, P.J., Jr., 1996, Episodic acidification of small streams in the northeastern United States-Effects on fish populations: Ecological Applications, v. 6, no. 2, p. 422-437.

Bailey, S.W., Horsley, S.B., and Long, R.P., 2005, Thirty years of change in forest soils of the Allegheny Plateau, Pennsylvania: Soil Science Society of American Journal, v. 69 , p. $681-690$.

Baldigo, B.P., and Murdoch, P.S., 1997, Effects of stream acidification and inorganic aluminum on mortality of brook trout (Salvelinus fontinalis) in the Catskill Mountains, New York: Canadian Journal of Fisheries and Aquatic Sciences, v. 54, p. 603-615.

Bricker, O.P., and Rice, K.R., 1989, Acidic deposition to streams: Environment Science and Technology, v. 23, no. 4, p. 379-385.

Cai, Meijun, Schwartz, J.S., Robinson, R.B., Moore, S.E., and Kulp, M.A., 2009, Long-term effects of acidic deposition on water quality in a high-elevation Great Smoky Mountains National Parks National Park watershed-Use of an ion input-output budget: Water Air Soil Pollution, doi: 10.1007/s11270-009-0187-5, 14 p. 
Charles, D.F., and Christie, S., eds. 1991, Acid deposition and aquatic ecosystems: New York, New York, Springer-Verlag, $747 \mathrm{p}$.

Childress, C.J.O., Foreman, W.T., Connor, B.F., and Maloney, T.J., 1999, New reporting procedures based on long-term method detection levels and some considerations for interpretations of water-quality data provided by the U.S. Geological Survey National Water Quality Laboratory: U.S. Geological Survey Open-File Report 99-193, 19 p.

Cook, R.B., Elwood, J.W., Turner, R.R., Bogle, M.A., Mulholland, P.J., and Palumbo, A.V., 1994, Acid-base chemistry of high-elevation streams in the Great Smoky Mountains National Parks: Water, Air, and Soil Pollution, v. 72 , p. 331-356.

Cosby, B.J., Webb, J.R., Galloway, J.N., and Deviney, F.A., 2006, Acidic deposition impacts on natural resources in Shenandoah National Park: National Park Service Technical Report NPS/NER/NRTR-2006/066, 35 p.

Coweeta Long Term Ecological Research, 2010, accessed February 14, 2010, at http://coweeta.uga.edu/pubcatalog.

Deyton, E.B., Schwartz, J.S., Robinson, R.B., Neff, K.J., Moore, S.E., and Kulp, M.A., 2009, Characterizing episodic stream acidity during stormflows in the Great Smoky Mountains National Park: Water Air and Soil Pollution, v. 196, p. $3-18$.

Dieffenbach, F.W., 2011, Appalachian National Scenic Trail vital signs monitoring plan: Natural Resource Report NPS/ NETN/NRR 2011/389, National Park Service, Fort Collins, Colo., $127 \mathrm{p}$.

Driscoll, C.T., 1985, Aluminum in acidic surface watersChemistry, transport, and effects: Environmental Health Perspectives, v. 63, p. 93-104.

Driscoll, C.T., Driscoll, K.M., Roy, K.M., and Mitchell, M.J., 2003, Chemical response of lakes in the Adirondack region of New York to declines in acidic deposition: Environmental Science and Technology, v. 37, p. 2036-2042.

Driscoll, C.T., Lawrence, G.B., Bulger, A.J., Butler, T.J., Cronan, C.S., Eagar, Christopher, Lambert, K.F., Likens, G.E., Stoddard, J.L., and Weathers, K.C., 2001, Acidic deposition in the northeastern United States-Sources and inputs, ecosystem effects, and management strategies: Bioscience, v. 51, no. 3, p. 180-198.

Driscoll, C.T., Lawrence, G.B., and Church, M.R., 1998, Recovery of surface waters in the northeastern U.S. from decreases in atmospheric deposition of sulfur: Water, Air, and Soil Pollution, v. 105, p. 319-329.
Dubrovsky, N.M., Burow, K.R., Clark, G.M., Gronberg, J.M., Hamilton, P.A., Hitt, K.J., Mueller, D.K., Munn, M.D., Nolan, B.T., Puckett, L.J., Rupert, M.G., Short, T.M., Spahr, N.E., Sprague, L.A., and Wilber, W.G., 2010, The quality of our Nation's waters-Nutrients in the Nations streams and groundwater, 1992-2004: U.S. Geological Survey Circular 1350, 174 p., accessed August 28, 2010, at http://water.usgs.gov/nawqa/nutrients/pubs/circ1350/.

Dufour, C., and Crisfield, E., eds. 2008, The Appalachian Trail MEGA-Transect: Appalachian Trail Conservancy, 31 p., accessed August 2010, at http://www.appalachiantrail.org/atf/cf/\%7BD25B4747-42A3-4302-8D48EF35C0B0D9F1\%7D/ATMEGATransectReport.pdf.

Elias, P.E., Burger, J.A., and Adams, M.B., 2009, Acid deposition effects on forest composition and growth on the Monongahela National Forest, West Virginia: Forest Ecology and Management, v. 258, p. 2175-2182.

Elliott, K.J., Vose, J.M., Knoepp, J.D., Johnson, D.W., Swank, W.T., and Jackson, William, 2008, Simulated effects of sulfur deposition on nutrient cycling in class 1 wilderness areas: Journal of Environmental Quality, v. 37, p. 14191431.

ESRI, 2009, National Park Service Natural Earth physical map. $500 \mathrm{~m}$ per pixel, accessed September 2009, at http://www.esri.com/software/arcgis/arcgisonline/ standard-maps.html.

Fenneman, N.M., and Johnson, D.W., 1946, Physiographic divisions of the conterminous U.S.: Washington, D.C., U.S. Geological Survey Special Map, scale 1:7,000,000, accessed March 12, 2008, at http://water.usgs.gov/lookup/ getspatial?physio.

Freeman, M.C., Pringle, C.M., and Jackson, C.R., 2007, Hydrologic connectivity and the contribution of stream headwaters to ecological integrity at regional scales: Journal of American Water Resources Association, v. 43, no. 1, p. 5-14.

Gesch, D.B., 2007, The National Elevation Dataset, in Maune, D., ed., Digital Elevation Model technologies and applications-The DEM Users Manual (2d ed.): Bethesda, Md., American Society for Photogrammetry and Remote Sensing, p. 99-118.

Gran, G., 1952, Determination of the equivalence point in potentiometric titrations-Part II, The Analyst, v. 77, p. 661-671.

Godfrey, P.J., 1988, Acid rain in Massachusetts: University of Massachusetts, Water Resources Research Center, publication no. 171, accessed August 17, 2010, at http://www. umass.edu/tei/wrrc/WRRC2004/pdf/acid\%20rain\%20booklet.pdf. 
Helsel, D.R., 2005, Nondetects and data analysis-statistics for censored environmental data: New York, John Wiley and Sons, $268 \mathrm{p}$.

Helsel, D.R., and Cohn, T.A., 1988, Estimation of descriptive statistics for multiply censored water quality data: Water Resources Research, v. 24, no. 12, p. 1997-2004.

Helsel, D.R., and Hirsch, R.M., 1992, Statistical methods in water resources: New York, Elsevier Science Publishers, $522 \mathrm{p}$.

Hem, J.D., 1992, Study and interpretation of the chemical characteristics of natural water ( $3 \mathrm{~d}$ ed.): U.S. Geological Survey Water-Supply Paper 2254, 263 p.

Hickman, R.E., and Fischer, J.M., 2007, Water quality of streams in and near the Delaware Water Gap National Recreation Area, Pennsylvania and New Jersey, 2002-04: U.S. Geological Survey Scientific Investigations Report 2007-5290, 65 p.

Hornbeck, J.W., Alexander, M.M., Eagar, Christopher, Carlson, J.Y., and Smith, R.B., 2001, Database for chemical contents of streams on the White Mountain National Forest: U.S. Department of Agriculture, Forest Service General Technical Report NE-282, $12 \mathrm{p}$.

Hubbard Brook Long Term Ecological Research, 2010, accessed February 14, 2010, at http://www.hubbardbrook. org/pubs/pub_search.php

Hyer, K.E., Webb, J.R., and Eshleman, K.N., 1995, Episodic acidification of three streams in Shenandoah National Park, Virginia, USA: Water, Air, and Soil Pollution, v. 85, p. 523-528.

Johnston, C.M., Dewald, T.G., Bondelid, T.R., Worstell, B.B., McKay, L.D., Rea, Alan, Moore, R.B., and Goodall, J.L., 2009, Evaluation of catchment delineation methods for the medium-resolution National Hydrography Dataset: U.S. Geological Survey Scientific Investigations Report 2009-5233, 88 p. (Also available at http://pubs.usgs.gov/ sir/2009/5233/pdf/sir2009-5233).

Kahl, J.S., and Scott, Matthew, 1988, Chemistry of Maine's high elevation lakes - Results from the HELM project: Lake and Reservoir Management, v. 4, no. 1, p. 33-39.

Kahl, J.S., Stoddard, J.L., Haeuber, Richard, Paulsen, S.G., Birnbaum, Rona, Deviney, F.A., Webb, J.R., DeWalle, D.R., Sharpe, William, Driscoll, C.T., Herlihy, A.T., Kellogg, J.H., Murdoch, P.S., Roy, Karen, Webster, K.E., and Urquhart, N.S., 2004, Have U.S. surface waters responded to the 1990 Clean Air Act Amendments?: Environmental Science and Technology, v. 38, no. 24, p. 484A-490A, doi: $10.1021 / \mathrm{es} 04046861$.
Keys, J. Jr., Carpenter, C., Hooks, S., Koenig, F., McNab, W.H., Russell, W., and Smith, M.L., 1995. Ecological units of the eastern United States-first approximation (CD-ROM), Atlanta, GA: U.S. Department of Agriculture, Forest Service. GIS coverage in ARCINFO format, selected imagery, and map unit tables. (Also available at http://www.srs.fs.usda.gov/econ/data/keys/index.htm).

King, P.B., and Beikman, H.M., 1974, Geologic map of the United States: U.S. Geological Survey Professional Paper 901, 40 p., accessed August 2010, at http://pubs.usgs.gov/ dds/dds11/pp901.pdf.

Latysh, N.E., and Wetherbee, G.A., in press, Improved mapping of National Atmospheric Deposition Program wetdeposition in complex terrain using PRISM-gridded data sets: Environmental Monitoring and Assessment.

Lawrence, G.B., 2002, Persistent episodic acidification of streams linked to acid rain effects on soil: Atmospheric Environment, v. 36, p. 1589-1598.

Lawrence, G.B., Momen, Bahram, and Roy, K.M., 2004, Use of stream chemistry for monitoring acidic deposition effects in the Adirondack Region of New York: Environmental Quality, v. 33, p. 1002-1009.

Likens, G.E., ed., 1985, An ecosystem approach to aquatic ecology: New York, Springer-Verlag, 516 p.

Likens, G.E., and Bormann, F.H., 1995, Biogeochemistry of a forested ecosystem ( $2 \mathrm{~d}$ ed.): New York, Springer-Verlag, $171 \mathrm{p}$.

Likens, G.E., and Buso, D.C., 2006, Variations in streamwater chemistry throughout the Hubbard Brook Valley:

Biogeochemistry, v. 78, p. 1-30.

MacKaye, B., 1921, An Appalachian Trail: A Project in Regional Planning: Journal of the American Institute of Architects, October.

Monteith, D.T., Stoddard, J.L., Evans, C.D., deWit, H.A., Forsius, Martin, Høgåsen, Tore, Wilander, Anders, Skjelkvåle, B.L., Jeffries, D.S., Vuorenmaa, Jussi, Keller, Bill, Kopácek, Jiri, and Vesely, Josef, 2007, Dissolved organic carbon trends resulting from changes in atmospheric deposition chemistry: Nature, v. 450 , no. 2 , doi:10.1038/nature06316, p. 537-540.

Mueller, D.K., Hamilton, P.A., Helsel, D.R., Hitt, K.J., and Ruddy, B.C., 1995. Nutrients in ground water and surface water of the United States - an analysis of data through 1992: U.S. Geological Survey Water Investigations Report, 1995, 95-4031, p. 74. 
Nadeau, Tracie-Lynn, and Rains, M.C., 2007, Hydrological connectivity between headwater streams and downstream waters-how science can inform policy: Journal of American Water Resources Association, v. 43, no. 1, p. $188-133$.

National Atmospheric Deposition Program, 1994a, Annual sulfate wet deposition, 1994, accessed August 29, 2010, at http://nadp.sws.uiuc.edu/ntn/grids.aspx.

National Atmospheric Deposition Program, 1994b, Annual nitrate wet deposition, 1994, accessed August 29, 2010, at http://nadp.sws.uiuc.edu/ntn/grids.aspx.

National Climatic Data Center, 2005, U.S. Climate Normals, accessed August 11, 2010, at http://cdo.ncdc.noaa.gov/ cgi-bin/climatenormals/climatenormals.pl

National Park Service, 1998, Baseline water quality data inventory and analysis - Curecanti National Recreation Area: National Park Service Technical Report NPS/ NRWRD/NRTR-98/181.

National Park Service, 2008, Appalachian National Scenic Trail resource management plan, accessed August 29, 2010, at http://www.nps.gov/appa/naturescience/index.htm.

Neff, K.J., Schwartz, J.S., Henry, T.B., Robinson, R.B., Moore, S.E., and Kulp, M.A., 2008, Physiological stress in native southern brook trout during episodic stream acidification in the Great Smoky Mountains National Parks National Park: Environmental Contamination and Toxicology, doi: 10.1007/s00244-008-9269-4, $12 \mathrm{p}$.

PRISM Climate Group, Oregon State University, 2006a, United States average monthly or annual maximum temperature, 1971-2000, accessed March 25, 2010, at http://prismclimate.org.

PRISM Climate Group, Oregon State University, 2006b, United States average monthly or annual precipitation, 1971-2000, accessed March 25, 2010, at http://prismclimate.org.

Reed, J.C., and Bush, C.A., 2005, Generalized geologic map of the conterminous United States: U.S. Geological Survey, National Atlas, accessed August 2010, at http://pubs.usgs.gov/atlas/geologic/.

Rice, K.C., and Bricker, O.P., 1995, Seasonal cycles of dissolved constituents in streamwater in two forested catchments in the mid-Atlantic region of the eastern USA: Journal of Hydrology, v. 170, no. 1-4, p. 137-158.

Rice, K.C., Deviney, F.A., Jr., Hornberger, G.M., and Webb, J.R., 2005, Predicting the vulnerability of streams to episodic acidification and potential effects on aquatic biota in Shenandoah National Park, Virginia: U.S. Geological Survey Scientific Investigations Report 2005-5259, 51 p.
Rice, K.C., Deviney, F.A., Jr., and Olsen, Gordon, 2007, Acid rain in the Shenandoah National Park, Virginia: U.S. Geological Survey Fact Sheet 2007-3057, 4 p.

Robinson, R.B., Barnett, T.W., Harwell, G.R., Moore, S.E., Kulp, M.A., and Schwartz, J.S., 2008, pH and acid anion time trends in different elevation ranges in the Great Smoky Mountains National Park: Journal of Environmental Engineering, v. 134, no. 9, p. 800-808.

Rochelle, B.P., and Church, M.R., 1987, Regional patterns of sulfur retention in watersheds of the eastern U.S.: Water, Air, and Soil Pollution, v. 36, no. 1-2, p. 61-73.

Rosfjord, C.H., Webster, K.E., Kahl, J.S., Norton, S.A., Fernandez, I.J., and Herlihy, A.T., 2007, Anthropogenically driven changes in chloride complicate interpretation of base cation trends in lakes recovering from acidic deposition: Environmental Science and Technology, v. 41, p. 7688 7693.

Rounds, S.A., 2006, Alkalinity and acid neutralizing capacity (version 3.0): U.S. Geological Survey Techniques of Water-Resources Investigations, book 9, chap. A6, section 6.6, July, accessed August 2008, from http://pubs.water.usgs.gov/twri9A6/.

SAS Institute, Inc., 2008, SAS OnlineDoc 9.1.3.: Cary, N.C., SAS Institute, Inc.

Seaber, P.R., Kapinos, P., and Knapp, G.L., 1987, Hydrologic unit maps: U.S. Geological Survey Water-Supply Paper 2294, 66 p.

Shriver, Greg, Maniero, Tonnie, Schwarzkopf, Kent, Lambert, Dan, Dieffenbach, Fred, Owen, Don, Wang, Y.Q., Nugranad-Marzilli, Joy, Tierney, Geri, Reese, Casey, and Moore, T.T., 2005, Appalachian Trail vital signs: National Park Service, Technical Report NPS/NER/NRTR-2005/026, $86 \mathrm{p}$.

Shubzda, J., Lindberg, S.E., Garten, C.T., and Nodvin, S.C., 1995, Elevational trends in the fluxes of sulfur and nitrogen in throughfall in the Southern Appalachian MountainsSome surprising results: Water, Air, and Soil Pollution, v. 85 , p. $2265-2270$.

Siemion, Jason, and Murdoch, P.S., 2010, Water quality of the Upper Delaware Scenic and Recreational River and tributary streams, New York and Pennsylvania: U.S. Geological Survey Scientific Investigations Report 2010-5009, 43 p.

Smith, R.A., Alexander, R.B., and Schwarz, G.E., 2003, Natural background concentrations of nutrients in streams and rivers of the conterminous United States: Environment Science \& Technology, v. 37, no. 14, p. 3039-3047. 
Stoddard, J.L., Kahl, J.S., Deviney, F.A., DeWalle, D.R., Driscoll, C.T., Herlihy, A.T., Kellogg, J.H., Murdoch, P.S., Webb, J.R., and Webster, K.E., 2003, Response of surface water chemistry to the Clean Air Act Amendments of 1990: U.S. Environmental Protection Agency, EPA/620/R-03/001, $78 \mathrm{p}$.

Stoddard, J.L., Urquhart, N.S., Newell, A.D., and Kugler, Danny, 1996, The Temporally Integrated Monitoring of Ecosystems (TIME) project design - 2, Detection of regional acidification trends: Water Resources Research, v. 32 , no. 8 , p. $2529-2538$.

Sullivan, T.J., Cosby, B.J., Herlihy, A.T., Webb, J.R., Bulger, A.J., Snyder, K.U., Brewer, P.F., Gilbert, E.H., and Moore, D.L., 2004, Regional model projections of future effects of sulfur and nitrogen deposition on streams in the southern Appalachian Mountains: Water Resources Research, v. 40, p. 1-16.

Sullivan, T.J., Webb, J.R., Snyder, K.U., Herlihy, A.T., and Cosby, B.J., 2007, Spatial distribution of acid-sensitive and acid-impacted streams in relation to watershed features in the Southern Appalachian Mountains: Water, Air, and Soil Pollution, v. 182, p. 57-71.

University of Virginia, Department of Environmental Sciences, 2010, Shenandoah Watershed and Virginia Trout Stream Sensitivity Study accessed February 15, 2010, at http://swas.evsc.virginia.edu/\#javascript.

U.S. Census, 2003, Locating urbanized area and urban cluster boundaries, accessed August 27, 2010, at http://www.census.gov/geo/www/ua/uaucbndy.html.

U.S. Department of Agriculture, Natural Resources Conservation Service, 2005, Watershed Boundary Dataset, accessed March 15, 2010, at http://www.ncgc.nrcs.usda. gov/products/datasets/watershed/.

U.S. Department of Agriculture, Natural Resources Conservation Service, Soil Survey Staff, updated 2006, U.S. General Soil Map (STATSGO2) for [State], accessed August 17, 2010, at http://soildatamart.nrcs.usda.

U.S. Department of Commerce, National Climatic Data Center, 2003, Climatography of the U.S. No. 85-Monthly divisional normals and standard deviations, accessed August 23, 2010, at http://www.ncdc.noaa.gov/oa/climate/normals/ usnormals.html.

U.S. Environmental Protection Agency, 2000, Nutrient Criteria: Technical guidance manual; rivers and streams: U.S. Environmental Protection Agency, EPA 822B-00002, 253 p., accessed June 2, 2011, at http://water.epa. gov/scitech/swguidance/standards/criteria/nutrients/ upload/2009_04_22_criteria_nutrient_guidance_rivers_ rivers-streams-full.pdf.
U.S. Environmental Protection Agency, 2002a, Quality Criteria for Water 1986: U.S. Environmental Protection Agency, Office of Water, EPA 440/5-86-001, 477 p., accessed September 10, 2010, at http://water.epa.gov/ scitech/swguidance/waterquality/standards/criteria/aqlife/ upload/2009_01_13_criteria_goldbook.pdf.

U.S. Environmental Protection Agency, 2002b, Summary table for the nutrient criteria documents: U.S. Environmental Protection Agency, Office of Water, 3 p., accessed August 30, 2010, at http://www.epa.gov/waterscience/criteria/ nutrient/ecoregions/files/sumtable.pdf.

U.S. Environmental Protection Agency, 2006a, National Hydrography Dataset Plus, accessed August 29, 2010, at http://www.epa.gov/waters.

U.S. Environmental Protection Agency, 2006b, National recommended water quality criteria, accessed August 29, 2010, at http://www.epa.gov/waterscience/criteria/wqcriteria.html.

U.S. Environmental Protection Agency, 2006c, Wadeable streams assessment-Assessing the nation's waters: U.S. Environmental Protection Agency EPA-841-F-06-001, 2 p.

U.S. Environmental Protection Agency, 2010a, Acid Rain Program progress - 2009 environmental results, accessed March 3, 2011, at http://www.epa.gov/airmarkets/progress/ ARP09_3.html.

U.S. Environmental Protection Agency, 2010b, Temporally Integrated Monitoring of Ecosystems and Long-Term Monitoring access March 1, 2010, at http://www.epa.gov/ airmarkt/assessments/TIMELTM.html

U.S. Environmental Protection Agency, 2010c, National Stream Survey Data Sets, accessed March 1, 2010, at http://www.epa.gov/emap2/html/data/surfwatr/data/nss.html

U.S. Geological Survey, 2000, National land cover dataset 1992 (NLCD): completed nationwide September 2000, accessed August 29, 2010, at http://seamless.usgs.gov/ products/nlcd92.php.

Webb, J.R., Cosby, B.J., Deviney, F.A., Jr., Galloway, J.N., Maben, S.W., and Bulger, A.J., 2004, Are brook trout streams in Western Virginia and Shenandoah National Park recovering from acidification?: Environmental Science and Technology, v. 38, no. 15, p. 4091-4096.

Wigington, P.J., Baker, J.P., DeWalle, D.R., Kretser, W.A., Murdoch, P.S., Simonin, H.A., Van Sickle, J., McDowell, M.K., Peck, D.V., and Barchet, W.R., 1996, Episodic acidification of small streams in the northeastern United StatesIonic controls of episodes: Ecological Applications, v. 6, no. 2, p. 389-407. 


\section{Appendix 1. Ancillary and Water-Quality Variable Definitions and Catchment Data (on CD-ROM)}


Prepared by the Pembroke Publishing Service Center.

For more information concerning this report, contact:

Director

U.S. Geological Survey

New Hampshire-Vermont Water Science Center

331 Commerce Way, Suite 2

Pembroke, NH 03275

dc_nh@usgs.gov

or visit our Web site at:

http://nh.water.usgs.gov 

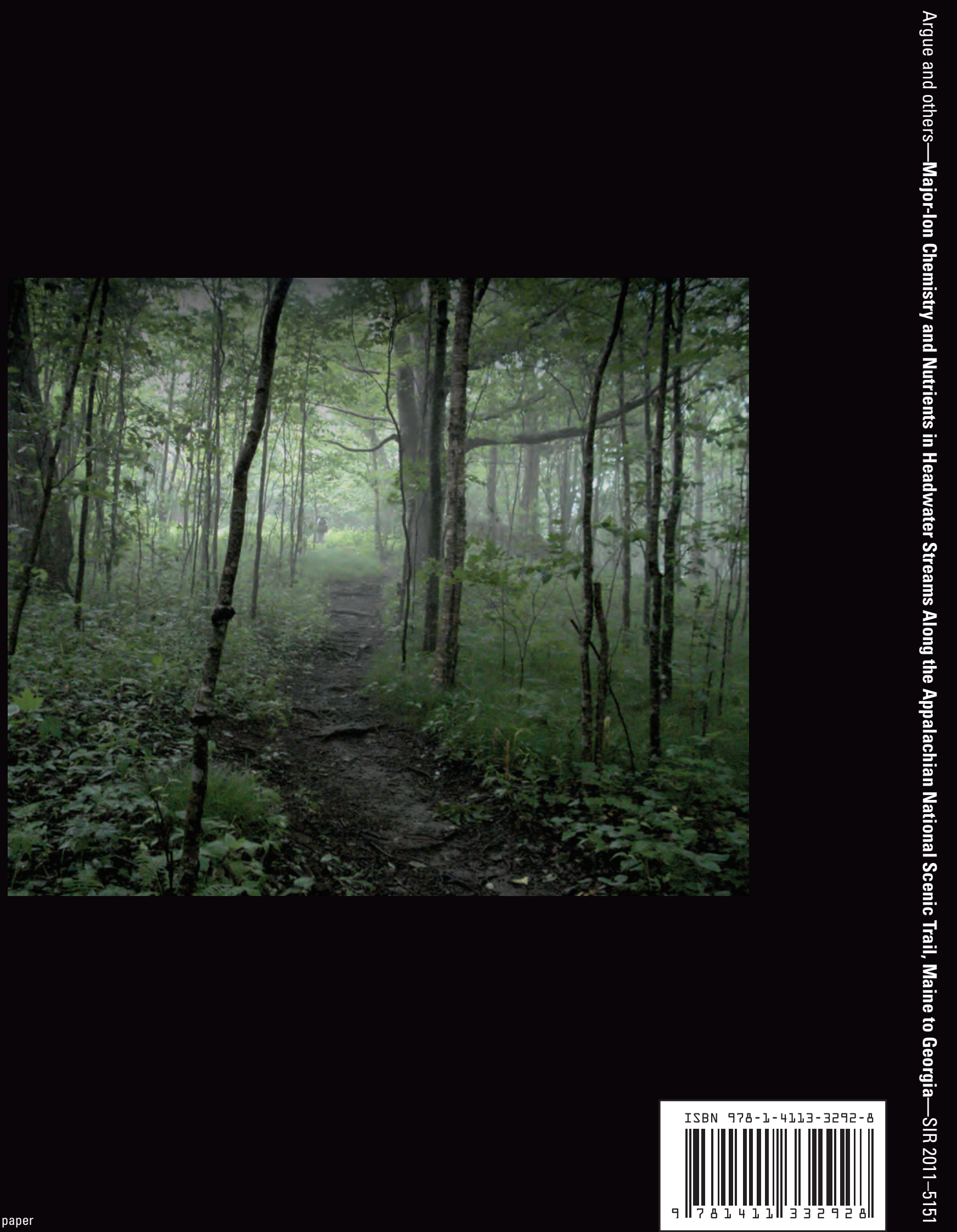